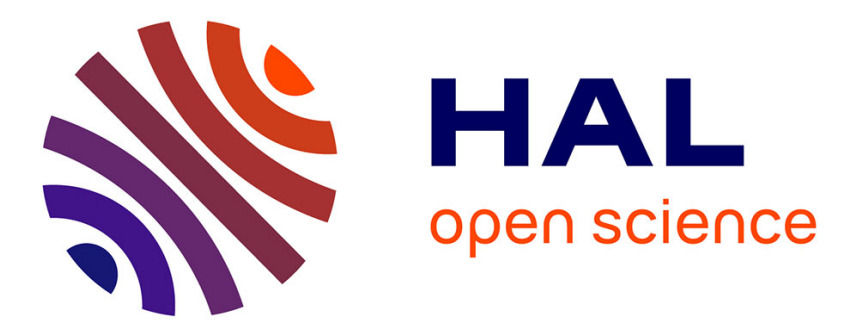

\title{
Coordination Polymers based on calixarene derivatives: Structures and properties
}

Alexander Ovsyannikov, Svetlana Solovieva, Igor Antipin, Sylvie Ferlay

\section{To cite this version:}

Alexander Ovsyannikov, Svetlana Solovieva, Igor Antipin, Sylvie Ferlay. Coordination Polymers based on calixarene derivatives: Structures and properties. Coordination Chemistry Reviews, 2017, 352, pp.151-186. 10.1016/j.ccr.2017.09.004 . hal-02300943

\section{HAL Id: hal-02300943 https://hal.science/hal-02300943}

Submitted on 25 Nov 2020

HAL is a multi-disciplinary open access archive for the deposit and dissemination of scientific research documents, whether they are published or not. The documents may come from teaching and research institutions in France or abroad, or from public or private research centers.
L'archive ouverte pluridisciplinaire HAL, est destinée au dépôt et à la diffusion de documents scientifiques de niveau recherche, publiés ou non, émanant des établissements d'enseignement et de recherche français ou étrangers, des laboratoires publics ou privés. 


\title{
Coordination Polymers based on calixarene derivatives: structures and properties
}

\author{
Alexander Ovsyannikov, ,a, Svetlana Solovieva, ${ }^{a c}$ Igor Antipina ${ }^{a s}$ and Sylvie Ferlay ${ }^{* *}$ \\ Kazan Federal University, Kremlevskaya str. 18, Kazan 420008, Russian Federation \\ - Molecular Tectonics Laboratory, Université de Strasbourg, CNRS, CMC UMR 7140, F-67000 Strasbourg, \\ France, \\ 'A. E. Arbuzov Institute of Organic and Physical Chemistry, Russian Academy of Science, Arbuzov str. 8, \\ Kazan 420088, Russian Federation \\ email: ferlay@unistra.fr
}

\begin{abstract}
The solid-state structures of 1D-3D Coordination Polymers based on the macrocyclic calixarene backbone has been reviewed, based on the chemical nature of appended substituents of macrocycle platform. The coordination propensity of this class of ligands is analysed, taking into account the different coordinating atoms/groups that can be located on the macrocyclic ligand: (1) the unmodified inherently coordinating thiacalix[4]arene with the $\mathrm{S}$ bridge a donor atoms; (2) different conformations of calix[n]arene units, with appended $\mathrm{O}$ donor atoms; (3) the chemical modification of the upper rim of calix[n]arenes and thiacalix[n]arenes, with coordinating groups, in particular the use of the sulfonate groups and (4) calix[4]arenes, thiacalix[4]arenes and tetramercaptothiacalix[4]rene that have been modified at their lower rim (mono, di and tetra substitution) using coordinating groups like cyano, carboxylate, pyridyl and pyrazolyl groups. All the formed coordination networks have been described. A special attention has been drawn to the structural and functional properties of these extended networks: magnetic, luminescence, adsorption and catalytic properties. Perspectives and future challenges in this emerging field are also discussed.
\end{abstract}

Keywords: Calixarene skeleton; Calix[4]Arene; ThiaCalix[4]Arene; TetraMercaptoThiaCalix[4]Arene; Calix[n]arene; Extended Coordination Polymers; Metallic cations; Coordination bonds ; Physical Properties ; Sorption Properties 
1 INTRODUCTION

1.1 Coordination Polymers

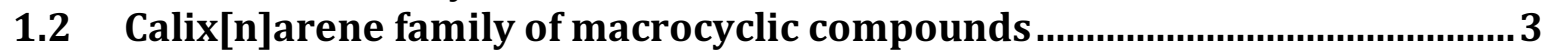

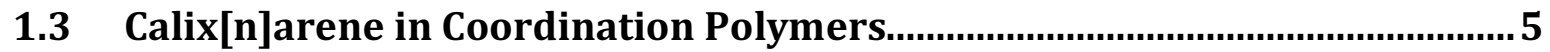

2 FORMATION OF COORDINATION POLYMERS USING CALIXARENE BACKBONES ............. 6 2.1. Calix[4]arene (CA) and Thiacalix[4]arene (TCA) without grafted binding sites

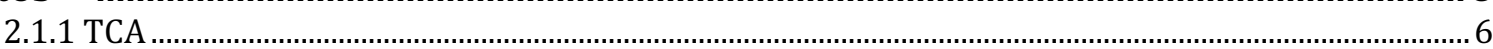

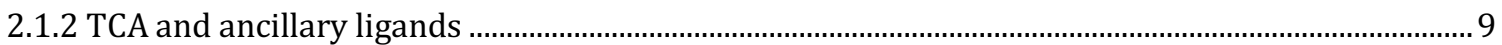

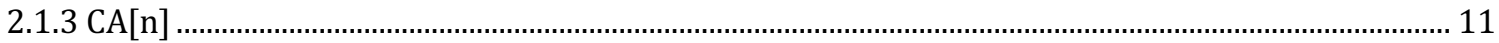

\subsection{Calix[n]arenes and thiacalix[n]arenes with Upper Rim appended} coordination sites

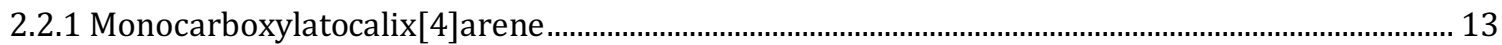

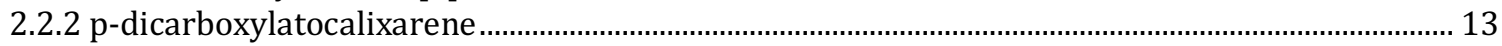

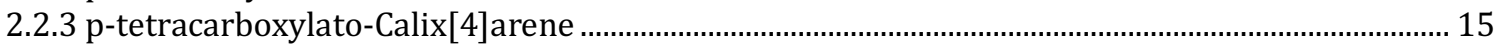

2.2.4 p-tetra m-(carboxyphenyl)-azocalix[4]arene ............................................................................... 15

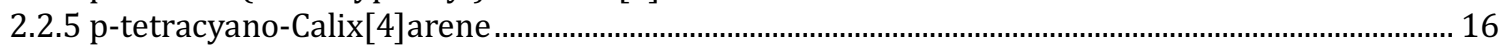

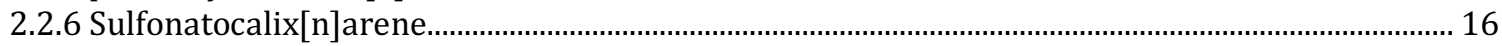

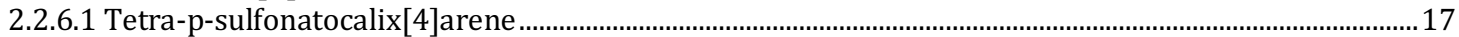

2.2.6.2 Tetra-p-sulfonatothiacalix[4]arene ............................................................................................................. 19

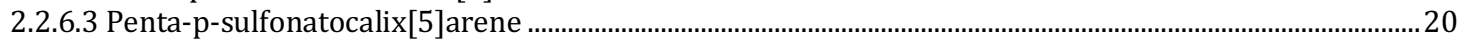

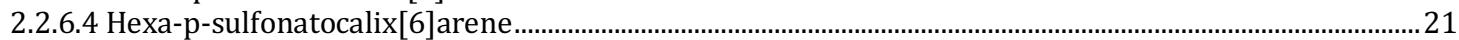

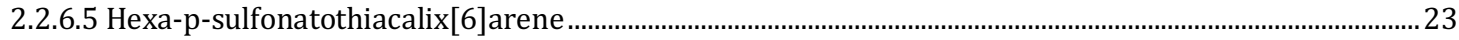

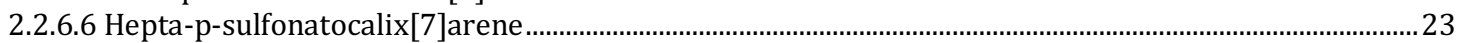

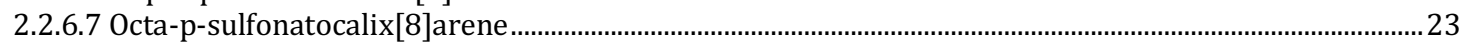

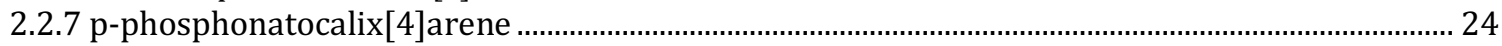

2.2.8 p-phosphineoxide-Calix[4]arene.................................................................................................... 25

2.3. Calix[4]arenes, thiacalix[4]arenes and tetramercaptothiacalix[4]rene with

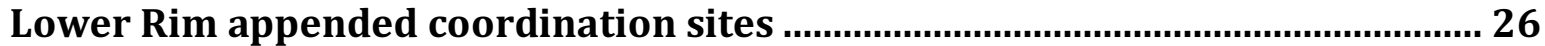

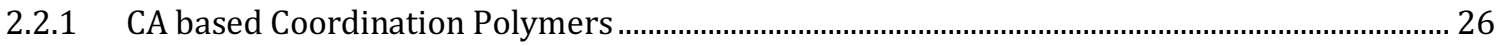

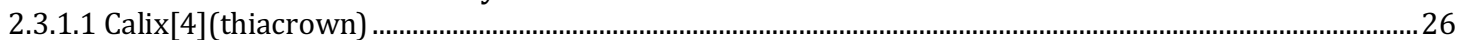

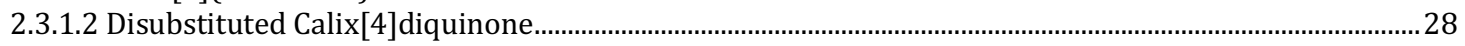

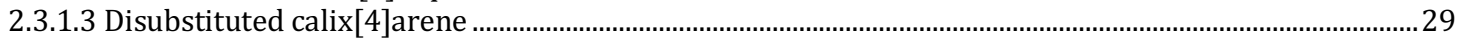

2.3.1.4 Tetrasubstituted calix[4] arene................................................................................................................................ 32

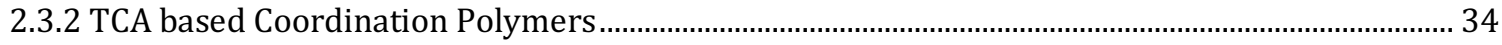

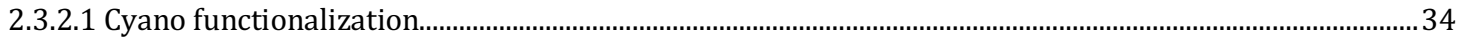

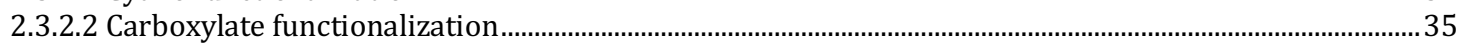

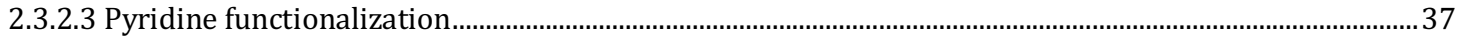

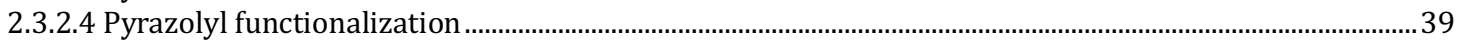

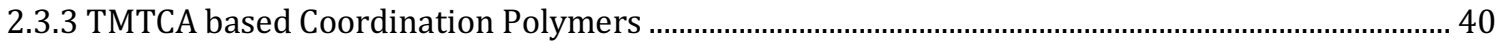

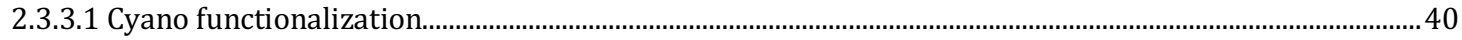

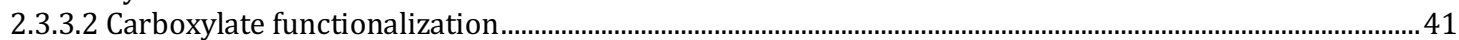

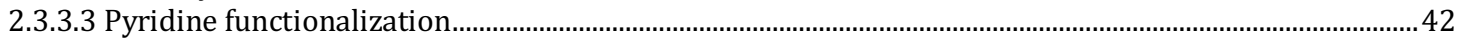

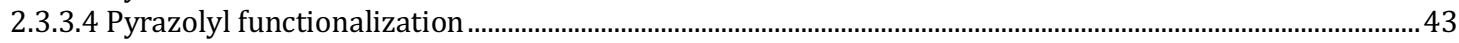

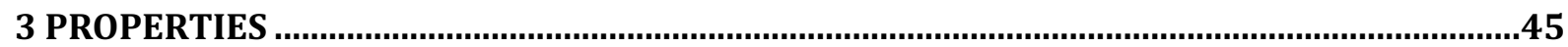

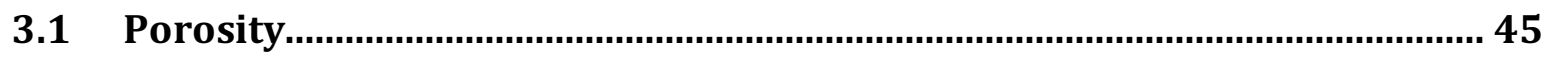

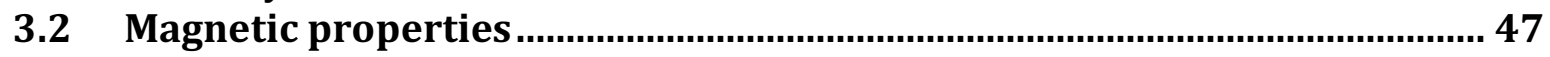

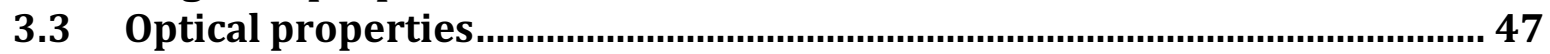

3.4 Luminescent properties in the solid state ...................................................... 48

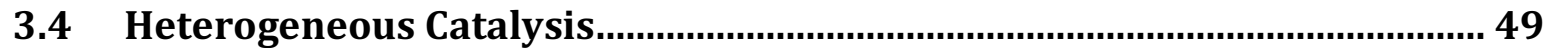

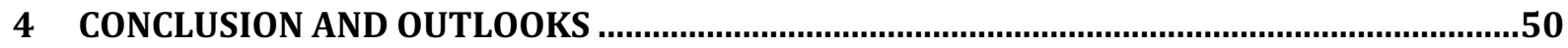

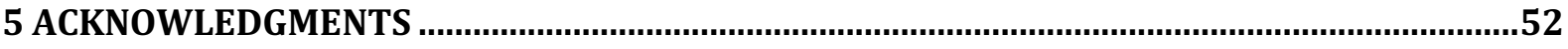

6 REFERENCES 


\section{INTRODUCTION}

\subsection{Coordination Polymers}

Design and synthesis of supramolecular architectures in the crystalline phase as materials with pre-determined structure/functional properties relationship based on macrocyclic compounds attracted a growing interest in recent decades. Coordination Polymers (CP) [1] or coordination networks [2] being defined (sometimes so-called MOFs [3]) as periodic architectures resulting from the bridging of organic ligands offering at least two divergently oriented coordinating sites and metal centres (or metal complexes), displaying at least two available coordination sites located in a divergent manner in coordination sphere. This type of organised compounds is fascinating with practically unlimited possibilities to be tuned by playing with the nature and geometry of structural components (metal cation as well as organic ligand) affording to creation of new functional molecular materials. The driving force for the formation of these extended assemblies is the formation of partially reversible coordination bonds between the organic ligands and metallic nodes.

The design and formation of this type or architecture still remains challenging [4] and the connectivity prediction between the different components remains difficult [5]. The interest for this class of solid-state molecular materials results from their multiple potential applications, resulting from structure/properties relationship, in catalysis, separation and storage for example and from the collective physical properties that some of these solids may exhibit: electronic, optic, magnetism, conduction, etc [6]. The key to success lies in the design of molecular building blocks that display the appropriate geometry, structure, chemical and physical properties of hydride organo-metallic system as well as in controlling on the molecular self-assembly leading to the periodic solid-state Coordination Polymers formation.

Different macrocycles have been already successfully used for the CP formation [7]. Some examples of $\mathrm{CP}$ based on the use porphyrine or cyclodextrine, or the combination of porphyrine and calixarenes macrocycles have also been reported [8]. To the best of our knowledge, no extensive review based in calixarene derivatives has been reported till now.

This review will be dedicated to the formation of Coordination Polymers based on the macrocyclic calix[n]arene unit. Several modifications of the organic ligands will be discussed, together with their structural impacts on the potential applications of the formed networks in different fields.

\subsection{Calix[n]arene family of macrocyclic compounds}

Calix[4]arene (figure 1) is a cyclic polyphenol that is synthetically available in a large scale. The upper rim is generally decorated by the presence of tert-butyl groups or $\mathrm{H}$ groups (leading to $p$-tert-butyl calix[n]arene or $p$ - $H$-calix[n]arene) or other chemical groups, whereas the lower rim presents phenolic $\mathrm{OH}$ or $\mathrm{SH}$ groups that can also be widely functionalised. Among many macrocyclic calixarene ligands already explored for the formation of Coordination Polymers, macrocyclic backbones such as Calix[4]Arene (CA), ThiaCalix[4] Arene (TCA) for which the four $\mathrm{CH}_{2}$ groups connecting the phenol moieties are replaced by four coordinating S atoms [9], and TetraMercaptoThiaCalix[4]Arene (TMTCA) where the 
coordinating phenoxy groups have been replaced by coordinating thioether groups [10] (figure 1), with a larger size of the macrocyclic cavity.

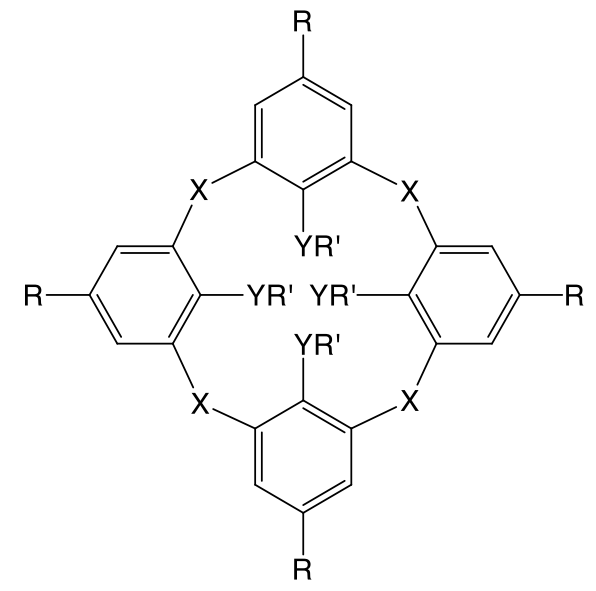

Figure 1: General representation of a calix[4] arene with $\mathrm{R}=$ upper rim organic substituent and $\mathrm{R}$ '=low rim organic substituent: Calix[4]Arene, $\mathbf{C A}\left(\mathrm{X}=\mathrm{CH}_{2}, \mathrm{Y}=\mathrm{O}\right)$ and ThiaCalix[4]Arene, TCA, $(\mathrm{X}=\mathrm{S}, \mathrm{Y}=\mathrm{O})$ and

TetraMercaptoThiaCalix[4]Arene, TMTCA $(\mathrm{X}=\mathrm{S}, \mathrm{Y}=\mathrm{S})$

A great interest of exploiting of calix[n]arenes (especially, calix[4]arenes) for the design of Coordination Polymers is favoured by their particular ability to adopt different conformations (cone, partial cone, 1,2-Alternate and 1,3-Alternate for calix[4]arene, figure 2) and the possibility of anchoring up to eight or more coordinating sites by functionalization of the lower and/or upper rims also varying the nature of the connecting groups between the phenolic units $\left(-\mathrm{CH}_{2}-\right.$ or $-\mathrm{S}$ bridges).

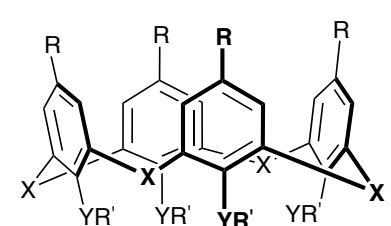

Cone

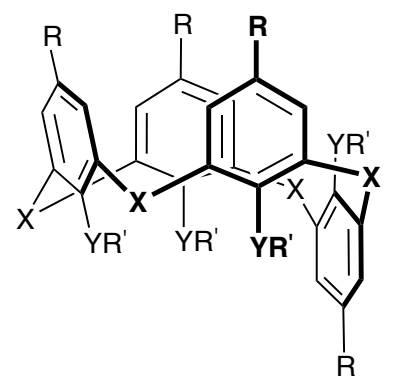

Partial cone

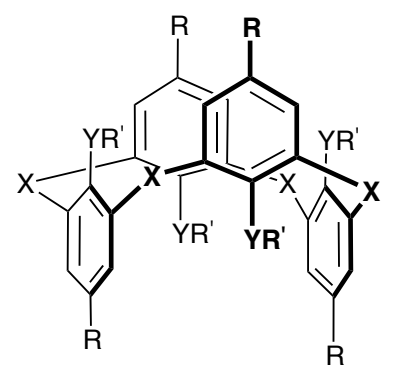

1,3-Alternate

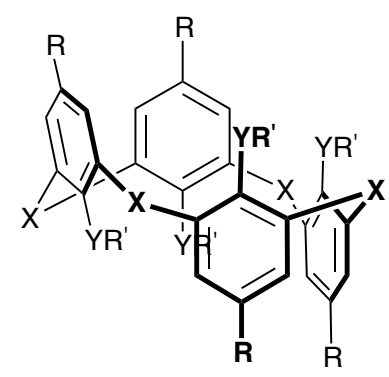

1,2-Alternate

Figure 2: Different conformers of calix[4] arene derivatives $\left(\mathrm{R}=\right.$ tert-Butyl or $\mathrm{H}, \mathrm{X}=\mathrm{CH}_{2}$ or $\mathrm{S}, \mathrm{Y}=\mathrm{O}$ or $\mathrm{S}$ and $\mathrm{R}^{\prime}=$ anchoring group)

During the last decades, a huge variety of architectures using calixarene backbone have been provided in creation of new supramolecular systems, based on the principles of molecular recognition and host-guest chemistry [11], [12].

The coordination abilities of unsubstituted calixarene derivatives, in order to obtain multinuclear complexes or cages, have also been extensively explored [13] but this is not the purpose of this review. As already mentioned, the coordination of lower rim unsubstituted CA and TCA adopted in cone conformation leads, in most of the cases, to the formation of isolated cluster units when combined with metallic salts (Figure 3), resulting from interaction of metal ions with macrocyclic coordination cavity composed of $4 \mathrm{O}$-phenolic atoms in the 
case of CA and 4 O-phenolic atoms with $4 \mathrm{~S}$ atoms in the case of TCA. The absence of additional coordinating groups in the structure of calixarene molecule prevents him to be involved in extended structures formation.

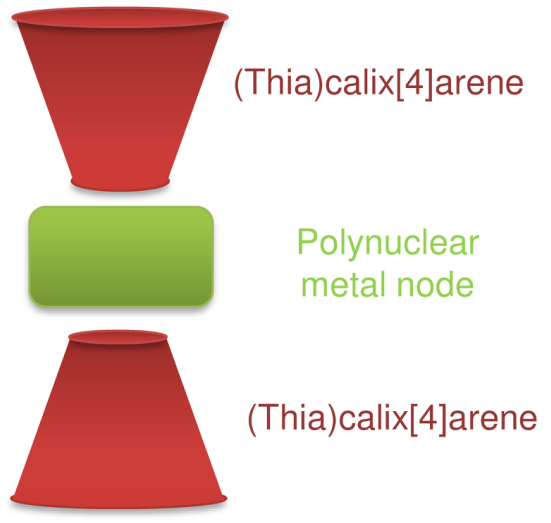

Figure 3: Schematic representation of the cluster discrete complex formation involving CA or TCA in cone conformation.

In this review, we will focus on the extended architectures formed with macrocyclic calixarenes. A special attention will be paid on building blocks based on CA, TCA and TMTCA, taking advantages of their coordinating differences. The chemical modification of the upper/lower rim of these entities will also be presented and discussed.

\subsection{Calix[n]arene in Coordination Polymers}

Extended structures containing calix[4]arenes have started to attract attention, because of their versatility, as already explained. Among the four possible conformers, the one blocked in the 1,3-Alternate conformation bearing peripheral binding sites is of particular interest for the formation of extended coordination networks, but this is of course not exclusive. There are also many examples concerning extended coordination networks based on calix[4]arene derivatives adopting cone conformation.

During this review, all presented possibilities of chemical functionalization of macrocycle backbone (lower and upper rim) will be explored. Furthermore, oxidation of the sulphur atom of the macrocyclic ring has been also performed leading sulfinyl (SO) [14] or sulfonyl $\left(\mathrm{SO}_{2}\right)$ [15] calixarene (mostly in cone conformation) that are widely involved in the formation of complexes but not in the formation of coordination networks.

The influence of the coordinating appended groups (upper and lower rim), as well as their number and nature, on the topology and function of formed networks will be discussed together with the nature and affinity of the used metals in the formed assemblies.

When the number of phenolic entities of calix[n]arene is more than 5 , the high flexibility of macrocyclic platform leads to observation of many different conformations in the Coordination Polymers formation. Several examples will illustrate this behaviour.

This review selectively highlights the Coordination Polymers formed with $L \mathbf{X}$ calixarene based ligands ( $X=1$ to 62 ). The synthesis of the ligands $\mathbf{L X}$ will not be discussed here, together with the synthesis of the formed Coordination Polymers that have been 
obtained using the classical techniques like self-assembly in solution under mild conditions or solvothermal (or hydrothermal) synthesis, proving the thermal stability of the presented $\mathbf{L X}$ calixarene based ligands. In some cases some $\mathrm{N}$ donor ancillary ligands have been used for the formation of high dimensional systems.

In this review, the presented Coordination Polymers, and this is a non-exhaustive list, have been all studied in the solid state, using $X$ ray diffraction on single crystals, for all the reported cases. Their connectivity will not be always discussed in details and we will focus on the properties exhibited by such systems. For all the depicted networks, usual colours have been used for the atoms: grey for carbon, blue for nitrogen, red for oxygen, yellow for sulphur, green for fluorine, dark green for chlorine, brown for bromine and purple for iodine.

\section{FORMATION OF COORDINATION POLYMERS USING CALIXARENE BACKBONES}

\subsection{Calix[4]arene (CA) and Thiacalix[4]arene (TCA) without grafted binding sites}

But in the same time for thiacalix[4]arene with the incorporated sulphur atoms which are responsible for the enlargement of the macrocyclic cavity together with the coordination abilities of macrocycle, Coordination Polymers were obtained with soft alkali, transition, and lanthanide metallic ions.

\subsubsection{TCA}

For this part, the used synthetic conditions leads to the formation of infinite Coordination Polymers instead of the well-known coordination clusters [13].

TCA (L1, cone conformation, figure 3 a), with its coordinating sulphur atoms in the ring of the macrocyle, leads to the formation of an extended networks when combined with transition metal ions, which was also observed with the parent compound where a non coordinating phenyl group has been appended at the upper rim (L2, cone conformation, figure 3 c): by mixing $\boldsymbol{L 1}$ or $\boldsymbol{L 2}$ (figure 4 a\&c) together with Copper(I) chloride, two 2D compounds with the same connectivity of formula $\left[\mathrm{Cu}_{2} \mathrm{Cl}_{2}(\boldsymbol{L 1})\right]\left(\mathrm{CH}_{3} \mathrm{OH}\right.$ ) (figure 4 b) and $\left[\mathrm{Cu}_{2} \mathrm{Cl}_{2}(\boldsymbol{L 2})\right]\left(\mathrm{CH}_{3} \mathrm{OH}\right)\left(\mathrm{CHCl}_{3}\right)_{0.5}$ (figure $4 \mathrm{~d}$ ) were obtained and their luminescent and magnetic properties in the solid state were also studied [16]. The connectivity of both 2D compounds are ensured by the affinity of the $\mathrm{Cu}(\mathrm{I})$ cations towards $\mathrm{S}$ atom, resulting the formation of the network. In both cases, the solid-state structures reveal the formation of dimeric $\mathrm{Cu}-\mathrm{Cu}$ units ( $\mathrm{Cu}-\mathrm{Cu}$ distances of 2.66 and $2.87 \AA$ ), that caused the luminescence properties of crystalline material. 


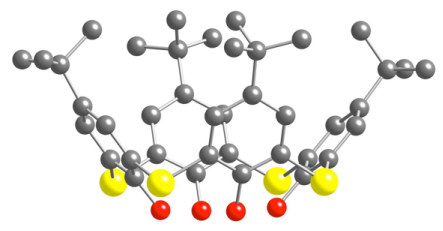

$L 1$

a

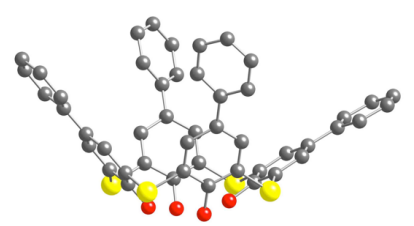

L2

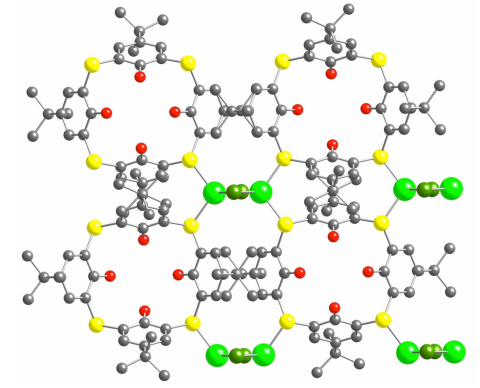

b

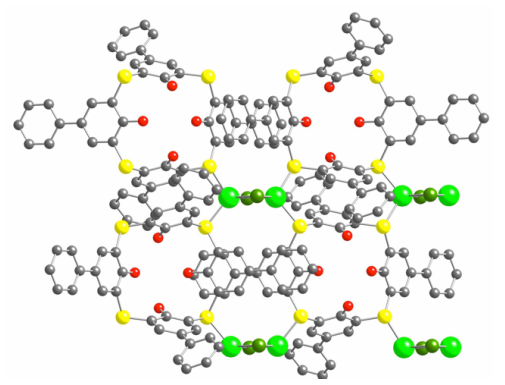

d

Figure 4: A portion of the X-ray structure showing the thiacalix[4]arene TCA (L1) (a), the upper rim modified of

$\operatorname{TCA}(\boldsymbol{L 2})$ (c) and the formation of the analogous $2 \mathrm{D}$ systems by coordinating the TCA with $\mathrm{CuCl}_{2}$ :

$\left[\mathrm{Cu}_{2} \mathrm{Cl}_{2}(\boldsymbol{L 1})\right]\left(\mathrm{CH}_{3} \mathrm{OH}\right)$ b) and $\left[\mathrm{Cu}_{2} \mathrm{Cl}_{2}(\boldsymbol{L 2})\right]\left(\mathrm{CH}_{3} \mathrm{OH}\right)\left(\mathrm{CHCl}_{3}\right)_{0 s}(\mathrm{~d})$. Light-green spheres represent $\mathrm{Cu}$ atoms. $\mathrm{H}$ atoms and solvent molecules are not presented for sake of clarity. Adapted from Ref. [16]

The second example of Coordination Polymer arises from very simple tetrasubstituted $p-\mathrm{H}-$ calix[4]arene by non coordinating alkyl chains (propyl or methyl) (L3-L5, 1,3-Alternate and cone), proposed by Lhotak et al., combined with AgTf salts. In all cases only sulphur atoms from the thioether junctions are involved in coordination with silver cations. The TCA molecules differ by their conformations (cone for $\mathbf{L 3}$ and $\mathbf{L 4}$, and 1,3-Alternate for $\mathbf{L 5}$ ) (figure $5 \mathrm{a}-\mathrm{c}$ ). All the obtained Coordination Polymers are 1D systems where the TCA derivatives are preorganized in a side-by-side arrangement, through $\mathrm{Ag}-\mathrm{S}$ bonds, and the chains are interconnected by triflate anions, leading to 2D Coordination Polymers of respective formulas $\left[(\boldsymbol{L 3})\left(\mathrm{AgCF}_{3} \mathrm{SO}_{3}\right)_{2}\right]\left(\mathrm{CH}_{3} \mathrm{COOCH}_{2} \mathrm{CH}_{3}\right)_{15},\left[(\boldsymbol{L 4})\left(\mathrm{AgCF}_{3} \mathrm{SO}_{3}\right)_{2}\right]$ and $\left[(\boldsymbol{L 5})\left(\mathrm{AgCF}_{3} \mathrm{SO}_{3}\right)_{2}\right]$ (figure $\left.5 \mathrm{~d}-\mathrm{f}\right)$ $[17]$.

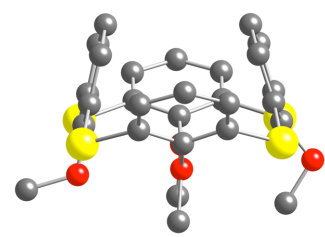

L3

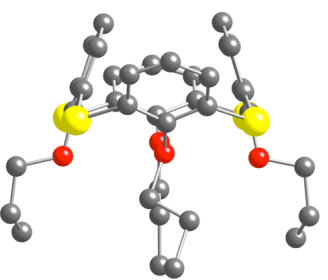

L4

b

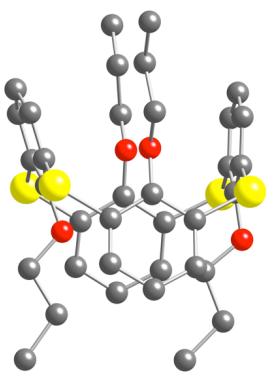

L5

c 

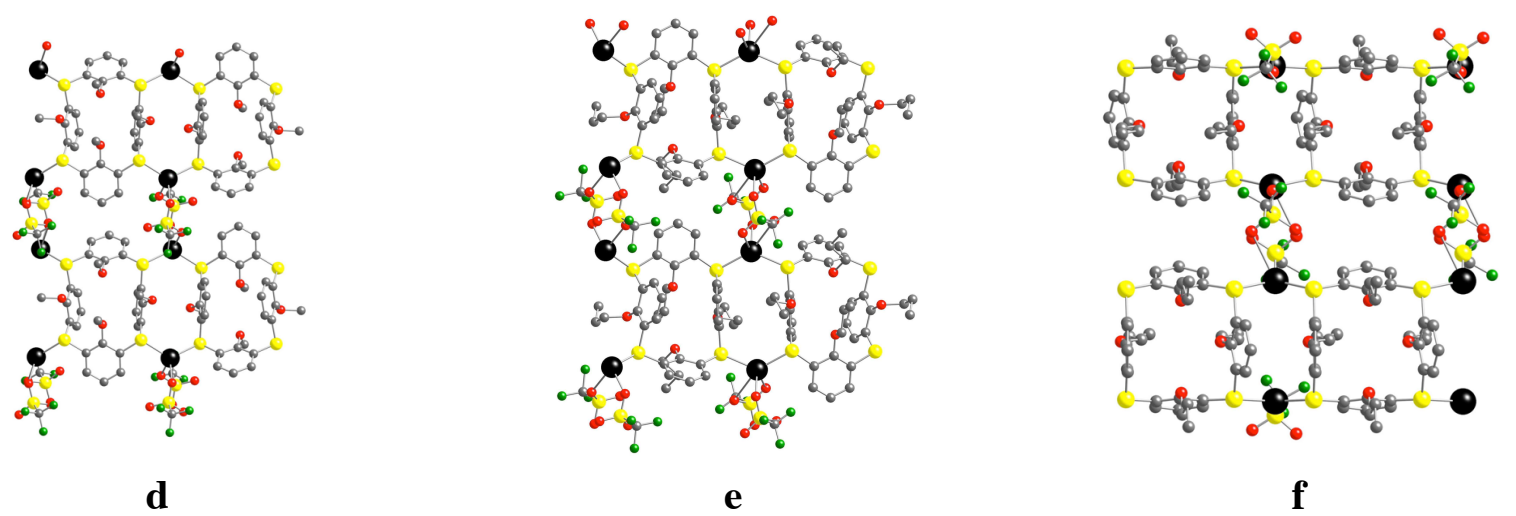

Figure 5: A portion of the X-ray structure showing the alkyl appended thiacalix[4]arene $\mathbf{L 3}-\mathbf{L 5}$ (a-c) in cone and 1,3-Alternate conformation, together with their corresponding 2D Coordination Polymers when combined with AgTf: $\left[(\boldsymbol{L 3})\left(\mathrm{AgCF}_{3} \mathrm{SO}_{3}\right)_{2}\right]\left(\mathrm{CH}_{3} \mathrm{COOCH}_{2} \mathrm{CH}_{3}\right)_{15}(\mathrm{~d}),\left[(\boldsymbol{L} \mathbf{4})\left(\mathrm{AgCF}_{3} \mathrm{SO}_{3}\right)_{2}\right](\mathrm{e})$ and $\left[(\boldsymbol{L} \mathbf{5})\left(\mathrm{AgCF}_{3} \mathrm{SO}_{3}\right)_{2}\right](\mathrm{f})$. Black spheres represent $\mathrm{Ag}$ atoms. $\mathrm{H}$ atoms, solvent molecules and anions are not presented for sake of clarity. Adapted from

Ref. [17]

Several examples of Coordination Polymers based on thiacalix[4]arene associated with alkali potassium cations with non coordinating groups were provided by Hamada et al. For example when thiacalix[4] arene is combined with $\mathrm{KH}$, a compound of formula structure [K $(\boldsymbol{L 1})](\mathrm{MeOH})$ with a 2D structure was obtained (figure $6 \mathrm{~b}$ ), through $\mathrm{O}$ and $\mathrm{S}$ coordination of the thiacalix[4]arene to $\mathrm{K}^{+}$cations [18]. The porous properties of the compound are presented. The more flexible dealkylated thiacalix[4]arene analogue (L6, figure 6 a) also leads to one dimensional compound of formula $\left[\mathrm{K}_{4}(\boldsymbol{L 6})\right](\mathrm{MeOH})\left(\mathrm{H}_{2} \mathrm{O}\right)_{1,5}$ through $\mathrm{O}$ and $\mathrm{S}$ coordination (figure $6 \mathrm{c}$ ) [19].Combinations using other alkali cations were performed, and an example of 1D supramolecular chains held by $\pi$-stacking with $\mathrm{Rb}^{+}$, of formula $[\mathrm{Rb}(\boldsymbol{L 6})](\mathrm{MeOH})_{2}$. has been reported (figure $6 \mathrm{~d}$ ) [20].

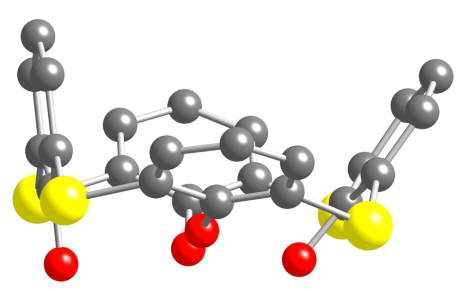

$L 6$

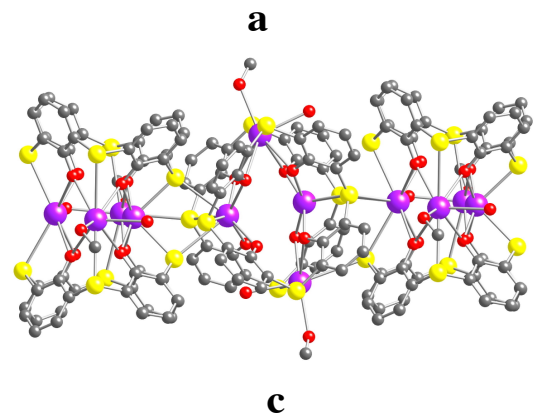

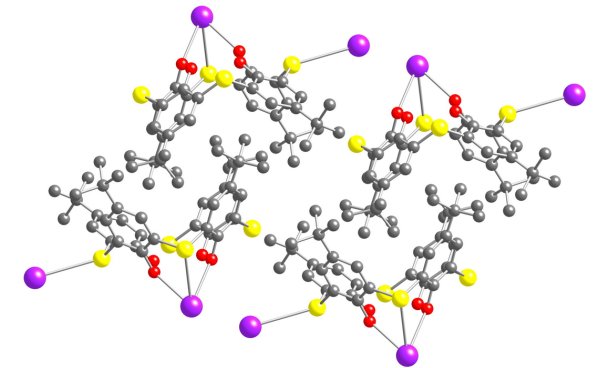

b

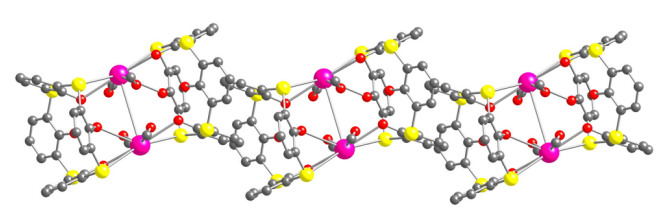

d

Figure 6: A portion of the X-ray structure showing the dealkylated ligand $\mathbf{L 6}$ in cone conformation (a), $\mathbf{L 1}$ combined with $\mathrm{KH}$, leading to a 2D system $[\mathrm{K}(\boldsymbol{L 1})](\mathrm{MeOH})(\mathrm{b})$, Potassium 1D Coordination Polymer $\left[\mathrm{K}_{4}(\boldsymbol{L 6})\right](\mathrm{MeOH})\left(\mathrm{H}_{2} \mathrm{O}\right)_{1 s}$ (c) and Rubidium 1D Coordination Polymer $[\mathrm{Rb}(\boldsymbol{L 6})](\mathrm{MeOH})_{2}(\mathrm{~d})$. Purplish-red and fuchsia spheres represent $\mathrm{K}$ and $\mathrm{Rb}$ atoms, respectively. $\mathrm{H}$ atoms and solvent molecules are not presented for sake of clarity. Adapted from Ref. [18-20] 
Only one example of Coordination Polymer based on thiacalix[8]arene (L7, figure 6 a) that adopts a partial cone conformation, has been combined with potassium cations, leading to a 1D system of formula $\left[\mathrm{K}_{4}(\boldsymbol{L} 7)\right](\mathrm{MeOH})_{14}\left(\mathrm{H}_{2} \mathrm{O}\right)_{2}$ (figure 7 b) [21], displaying a zeolitic structure, was also reported by Hamada et al.. The desolvated Coordination Polymer can adsorb such gaseous organic guest molecules as methanol and benzene.

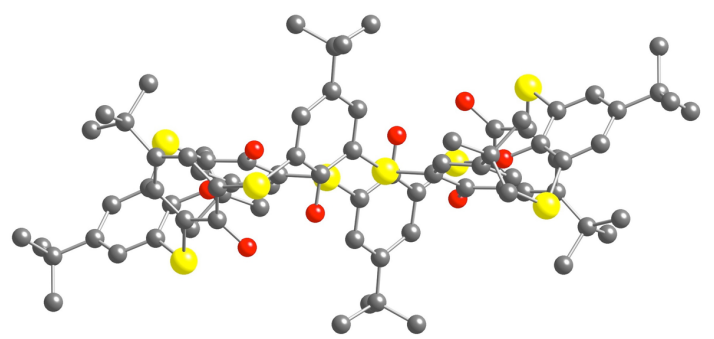

L7

a

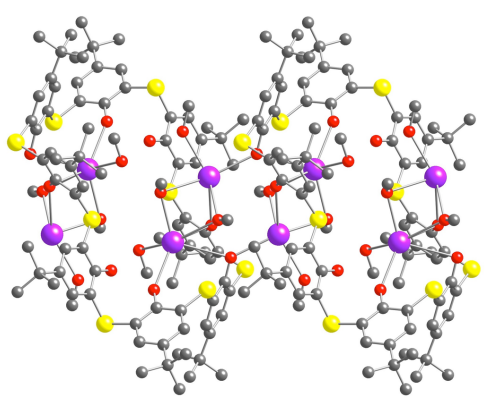

b

Figure 7: A portion of the X-ray structure showing the thiacalix[8]arene $\boldsymbol{L 7}$ (a) together with its corresponding

1D Coordination Polymer obtained with $\mathrm{K}_{+}$, of formula $\left[\mathrm{K}_{4}(\boldsymbol{L 7})\right](\mathrm{MeOH})_{4}\left(\mathrm{H}_{2} \mathrm{O}\right)_{2}($ b). Purplish-red spheres represent $\mathrm{K}$ atoms. $\mathrm{H}$ atoms and solvent molecules are not presented for sake of clarity. Adapted from Ref. [21]

\subsubsection{TCA and ancillary ligands}

There are several examples where unsubstituted TCA (L1, cone conformation, figure 4a), sulfonyl TCA (L8, cone conformation, figure 8) or phenyl TCA ( $\mathbf{L 2}$, cone conformation, figure $4 \mathrm{c}$ ) have been used for the building of high dimensional Coordination Polymers, combined together with ancillary di- or polytopic ligands $(\mathrm{O}$ or $\mathrm{N}$ donor rigid ligands, Figure 8 ) and metallic cations. The role of the ancillary ligands essentially is based on the bridging of the already formed tetranuclear $\left[\mathrm{M}_{4} \mathrm{~L}\right]$ clusters $(\mathrm{M}=\mathrm{Co}$ mainly or $\mathrm{Fe})$.

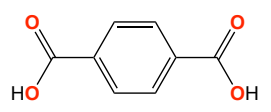

tphta
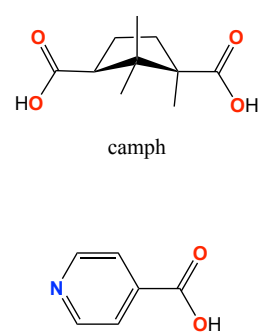

ina

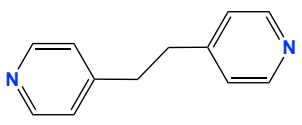

bpa

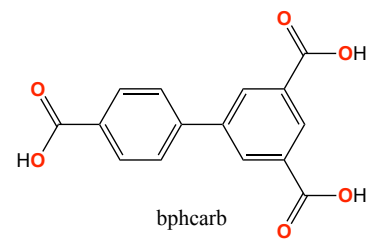<smiles>O=C(O)c1ccc(-c2cccc(-c3ccc(C(=O)O)cc3)c2)cc1</smiles>

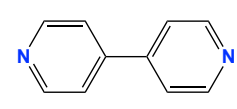

bpy

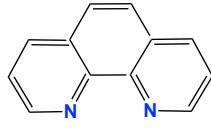

phen

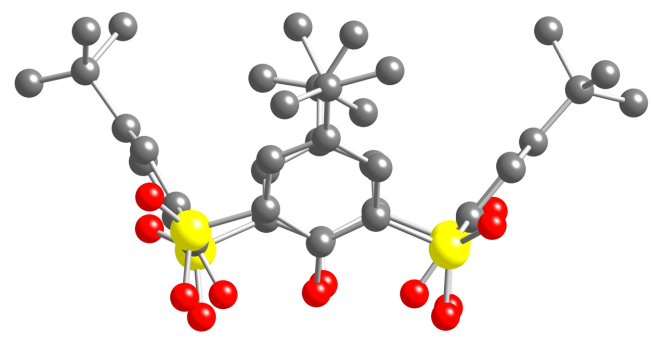

L8

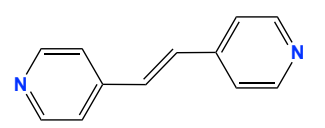

bpe 
Figure 8: (Left) Ancillary ligands (N or O donor) used in Coordination Polymers formation with the TCA (L1), sulfonyl TCA (L8) or phenyl TCA $(\boldsymbol{L 2})$; (Right) the sulfonyl TCA $\boldsymbol{L} 8$.

The first reported compound, based on the use of $\left[\mathrm{Co}_{4} \mathrm{~L}\right]$ units and TCA ( $\boldsymbol{L} \mathbf{1}$, figure $\left.4 \mathrm{a}\right)$, presents the following formula $\left[\left(\mathrm{Co}_{4} \mathrm{Cl}_{2}\left(\mathrm{H}_{2} \mathrm{O}\right)_{2}(\boldsymbol{L 1})\right] \mathrm{Cl}(\mathrm{tphta})_{2}\right]$ with tphta $=$ terephtalate ligand (figure 8 ), and is a 2D system, where the wave-like belts are bridged by some chloride anions into 2D layers (figure 9 a) [22]. The second system is based on the use of a tricarboxylate ligand, and a compound of formula $\left\{[\mathrm{Co}+\mathrm{Cl}(\boldsymbol{L 1})]\left[\mathrm{Co} / 4(\boldsymbol{L 1})\left(\mathrm{CH}_{3} \mathrm{OH}\right)_{2}\left(\mathrm{H}_{2} \mathrm{O}\right)_{2}\right]\right\}$ (bphcarb $)_{2}$ with bphcarb = biphenyl-3,40,5-tricarboxylate ligand (figure 8), with a 1D feature and zigzag 1D ladder-like connectivity pattern (figure $9 \mathrm{~b}$ ) is obtained [23]. For this $1 \mathrm{D}$ compound, the $\mathrm{N}_{2}$ adsorption properties have been measured.

Another example arising from the use of the isonicotinate (ina) ancillary ligand, leads to a two dimensional system of formula $\left\{\left[\mathrm{M}_{4}{ }_{4} \mathrm{Cl}(\boldsymbol{L 1})(\text { ina) })_{4}\right]\left(\mathrm{M}^{\mathrm{H}} \mathrm{Cl}_{2}\right)\right\} \mathrm{M}^{\mathrm{n}}=\mathrm{Fe}$ or Co (figure 9 c) [24]. $\mathrm{N}_{2}$ adsorption properties have been reported, since these networks presents pores with 7.5 $\mathrm{x} 13.2 \AA$ size.

Using 4,4'-bipyridyl linkers (bpy) combined with in situ formed methanolate anions, and an oxidised TCA in sulfonyl $\boldsymbol{L 8}$ (figure 8), a 1D compound of formula $\left\{\left[\mathrm{Co}_{3}\left(\mathrm{H}_{2} \mathrm{O}\right)(\boldsymbol{L 8})(\mathrm{HCOO})_{2}\right]_{2}(\right.$ bpy $\left.)\right\}$ was formed with a $\mathrm{Co}(\mathrm{II})$ salt (figure $9 \mathrm{~d}$ ) [25]. The $\mathrm{N}_{2}$ adsorption properties have been measured for this compound together with magnetic properties.

The solvothermal synthesis of phenyl TCA $(\boldsymbol{L 2}$, figure $4 \mathrm{c})$ with $(1 \mathrm{R}, 3 \mathrm{~S})-(+)$-camphoric acid (camph (figure 8)) leads to a two dimensional compound of formula $\left[\mathrm{Co}_{8}(\boldsymbol{L 2})_{2}(\mathrm{Camph})_{3} \boldsymbol{\mu}_{4^{-}}\right.$ $\mathrm{Cl}_{2}$ ] (figure 9 e) [26]. The magnetic properties of these compounds have been briefly analysed, while its sorption properties have been measured and revealed no permanent porosity. The last reported compound based on the presence of $\left[\mathrm{Co}_{4} \mathrm{~L}\right]$ units, presents the following formula $\left[\mathrm{HCo}_{4} \mathrm{Cl}(\boldsymbol{L 1}](\mathrm{DCPB})_{2}\right]$ with $\mathrm{DCPB}=1,3-\mathrm{di}(4$-carboxy- phenyl)benzene (figure 8$)$, is a $1 \mathrm{D}$ system, behaving as a zigzag chain, with long DCPB spacers between the $\left[\mathrm{Co}_{4} \mathrm{~L}\right]$ units (figure 9 f) [27]. The $\mathrm{N}_{2}$ adsorption properties have been measured using this compound.

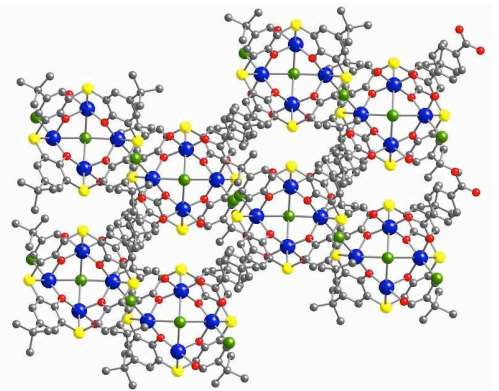

a

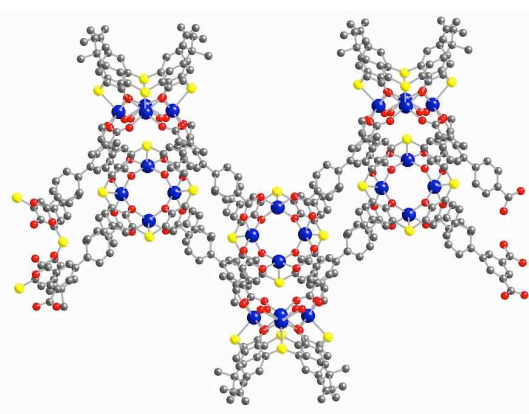

b

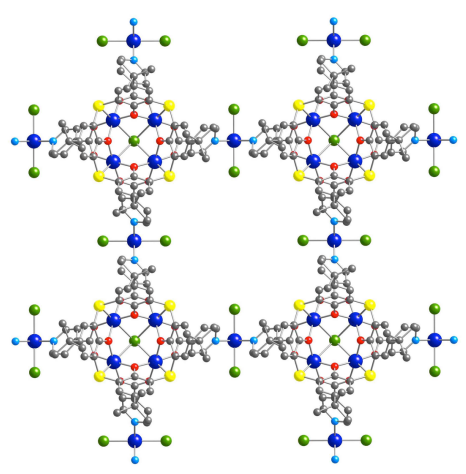

c 


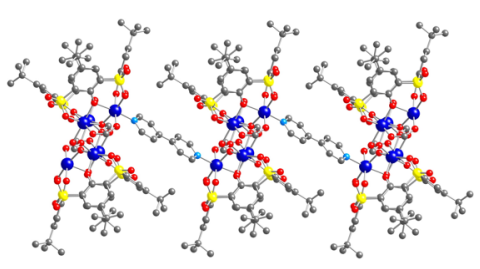

d

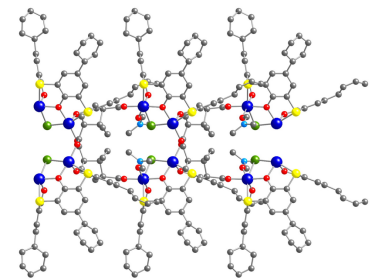

e

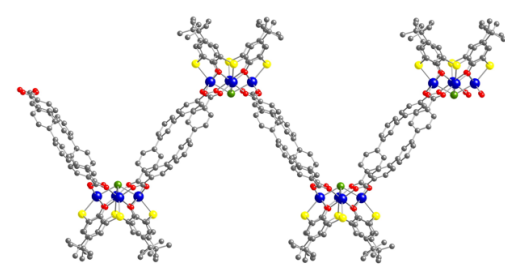

f

Figure 9: A portion of the X-ray structure showing thiacalix[4]arene TCA (L1, figure 4 a), sulfonyl TCA ( $\boldsymbol{L 8}$, figure 8) or phenyl TCA ( $\boldsymbol{L 2}$, figure $4 \mathrm{c}$ ) combined with ancillary ligands leading to a

$\left[\left(\mathrm{Co}_{2} \mathrm{Cl}_{2}\left(\mathrm{H}_{2} \mathrm{O}\right)_{2}(\boldsymbol{L 1})\right] \mathrm{Cl}(\text { tphta })_{2}\right] 2 \mathrm{D}$ system (a), $1 \mathrm{D}$ zigzag chain of formula $\left\{[\mathrm{Co}, \mathrm{Cl}(\boldsymbol{L} \mathbf{1})]\left[\mathrm{Co}{ }_{3} \mathrm{Cl}(\boldsymbol{L} \mathbf{1})\right.\right.$

$\left.\left.\left(\mathrm{CH}_{3} \mathrm{OH}\right)_{2}\left(\mathrm{H}_{2} \mathrm{O}\right)_{2}\right]\right\}(\text { bphcarb })_{2}$ (b), or a $2 \mathrm{D}$ system of formula $\left\{\left[\mathrm{M}_{4} \mathrm{Cl}(\boldsymbol{L 1})(\mathrm{ina})_{4}\right]\left(\mathrm{MCCl}_{2}\right)\right\}(\mathrm{c}), 1 \mathrm{D}$ chain of formula $\left\{\left[\mathrm{Co}_{3}\left(\mathrm{H}_{2} \mathrm{O}\right)(\boldsymbol{L 8})(\mathrm{HCOO})_{2}\right]_{2}\left(4,4^{\prime}\right.\right.$-bpy $\left.)\right\}$ (d) the 2D chiral compound $\left[\mathrm{Co}_{3}\left((\boldsymbol{L 2})_{2}(\mathrm{camph})_{3} \mu_{1}-\mathrm{Cl}_{2}\right]\right.$ (e) and the 1D zigzag $\left[\mathrm{HCo}_{4} \mathrm{Cl}((\boldsymbol{L 1})](\mathrm{DCPB})_{2}\right](\mathrm{f})$. Dark-blue spheres represent $\mathrm{Co}$ atoms. $\mathrm{H}$ atoms, solvent molecules and anions are not presented for sake of clarity. Adapted from Ref. [22-27]

Some of obtained coordination materials, when activated, present some porous properties, but with rather low surface areas.

\subsection{3 $C A[n]$}

Two examples are provided with calix[4]arene substituted at their upper rim with noncoordinating groups.

The first example involves a calix[4]arene substituted at its upper rim with non coordinating tetra-allyl groups, ligand $\boldsymbol{L 9}$, as shown in figure 10 a. When this ligand is combined with different [28] silver salts (perchlorate and nitrate), two Coordination Polymers are observed, resulting from Ag- $\pi$ interaction: a zigzag chain of formula $\left[(\boldsymbol{L 9})\left(\mathrm{AgClO}_{4}\right)_{2}\right]$ $2\left(\mathrm{CH}_{3}\right)_{2} \mathrm{CO} \cdot \mathrm{H}_{2} \mathrm{O}$ (figure $10 \mathrm{~b}$ ) and a 3D system of formula $\left[(\boldsymbol{L 9})\left(\mathrm{AgNO}_{3}\right)_{4}\right]\left(\mathrm{CH}_{3}\right)_{2} \mathrm{CO} \cdot \mathrm{H}_{2} \mathrm{O}$ (figure $10 \mathrm{c})$. The $\mathrm{Ag}-\mathrm{C}$ distances are in the 2.37-2.52 $\AA$ range. The compounds exhibit luminescence properties.
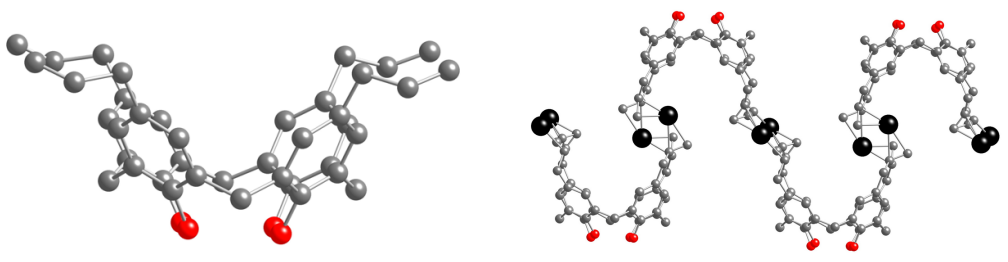

L9 b

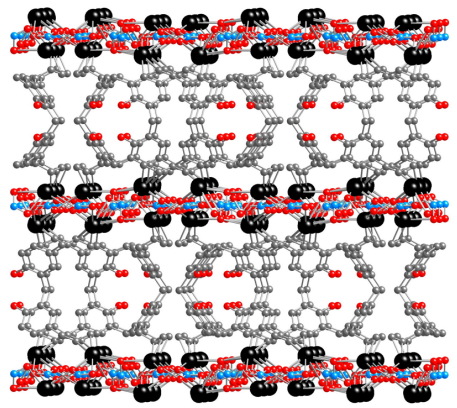

C

Figure 10: A portion of the X-ray structure showing ligand $\boldsymbol{L 9}$ (a), the 1D Coordination Polymer of formula $\left[(\boldsymbol{L 9})\left(\mathrm{AgClO}_{4}\right)_{2}\right] 2\left(\mathrm{CH}_{3}\right)_{2} \mathrm{CO} \mathrm{H}_{2} \mathrm{O}$ (b) and the 3D system of formula $\left[(\boldsymbol{L 9})\left(\mathrm{AgNO}_{3}\right)_{4}\right]\left(\mathrm{CH}_{3}\right)_{2} \mathrm{CO} \mathrm{H}_{2} \mathrm{O}$. Black spheres represent $\mathrm{Ag}$ atoms. $\mathrm{H}$ atoms, solvent molecules and anions are not presented for sake of clarity. Adapted from Ref. [21] 
The combination of the sodium salt of $p$-H-calix[8] arene $\mathbf{L 1 0}$ (figure 11 a) with $\mathbf{U C l}_{4}$ leads to the formation of a $1 \mathrm{D}$ polymer of formula $\left[\mathrm{U}_{2}(\mathrm{acac})_{6}(\boldsymbol{L 1 0})(\mathrm{py})_{4} \mathrm{Na}_{4}\right]$ (figure $11 \mathrm{~b}$ ), where polymeric chains with $\left[\mathrm{Na}_{2}(\mathrm{acac})_{4}\right]$ units are bridging tetranuclear $\left[\mathrm{Na}_{2} \mathrm{U}_{2}(\mathrm{acac})_{2}(\boldsymbol{L 1 0})\right]$ [29]. In this case, the flexible macrocyle is twisted in a propeller fashion, comprising two partial cone conformations. The combination of flexible $p$-tert-butylcalix[6] arene $\boldsymbol{L 1 1}$ (figure 11 c) with $\left[\mathrm{LiVO}(\mathrm{Ot}-\mathrm{Bu})_{4}\right]$ leads to the $1 \mathrm{D}$ bimetallic system of formula $\left[\left(\mathrm{VO}_{2}\right)_{2}\left(\boldsymbol{L} \mathbf{1 1} \mathbf{H}_{2}\right)_{-}\right.$ $\left.\left(\mathrm{Li}(\mathrm{MeCN})_{2}\right)_{2}\right] \cdot 2 \mathrm{MeCN}$ (figure $11 \mathrm{~d}$ ) [30]. This compound presents catalytic properties for ethylene homo-(co-)polymerization.

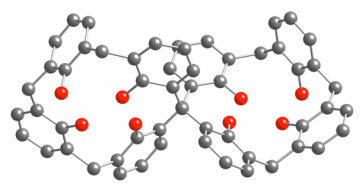

$L 10$

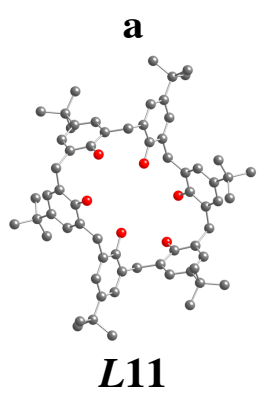

c

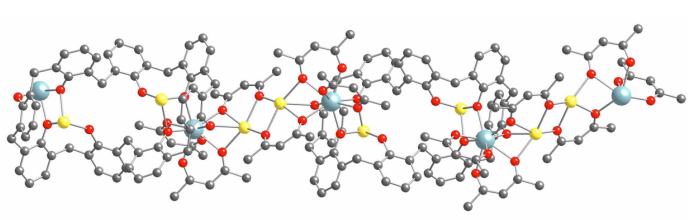

b

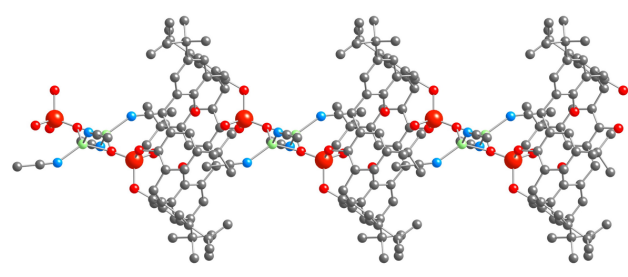

d

Figure 11: A portion of the X-ray structure showing $p$-H-calix[8]arene $\boldsymbol{L 1 0}$ twisted in a propeller fashion (a), the resulting 1D Coordination Polymer $\left[\mathrm{U}_{2}(\mathrm{acac})_{(}(\boldsymbol{L 1 0})(\mathrm{py})_{\mathrm{Na}_{1}}\right](\mathrm{b}), p$-tert-butylcalix[6]arene $\boldsymbol{L 1 1}$ (c) and the resulting 1D Coordination Polymer $\left[\left(\mathrm{VO}_{2}\right)_{2}(\boldsymbol{L 1 1 H})_{2}-\left(\mathrm{Li}(\mathrm{MeCN})_{2}\right)_{2}\right] \cdot 2 \mathrm{MeCN}(\mathrm{d})$. Light-yellow, light-blue, lightgreen and scarlet-red spheres represent $\mathrm{Na}, \mathrm{U}, \mathrm{Li}$ and $\mathrm{V}$ atoms, respectively. $\mathrm{H}$ atoms, solvent molecules and anions are not presented for sake of clarity. Adapted from Ref. [29-30]

In conclusion, very few examples of extended Coordination Polymers are provided, the rigidity of TCA seems to prevent the possibilities of extension. The choice of appropriated metals is also restricted, and when TCA is used, the affinity with sulphur atom is the driving force of the construction of the network. When ancillary ligands are used, much different but still not rational networks are formed presenting porous properties.

\subsection{Calix[n]arenes and thiacalix[n]arenes with Upper Rim appended coordination sites}

In this section, the chemical functionalization of the upper rim of calixarene with coordinating groups will be explored and discussed.

Upper-rim $p$-sulfonated calix[n]arene and thiacalix[4]arene have been mostly used to prepare very different Coordination Polymers (transition metals and also lanthanides) and several examples are provided, together with the use of phosphonatocalixarene and carboxylatocalixarene. 


\subsubsection{Monocarboxylatocalix[4]arene}

Examples of 1D coordination molecular panels obtained by using the upper rim monocarboxyl derivative of $p$-H-propoxycalix[4]arene) in cone conformation have been reported by Dalgarno et al. ( $\mathbf{L 1 2}$, figure 12 a). Reaction of this deprotonated calixarene species with $\mathrm{CoCl}_{2}$ and three different ancillary $\mathrm{N}$ donor bipyridyl ligands (bpy, bpe and bpa, see figure 8), leads to isoreticular 1D Coordination Polymers of formula $\left[\mathrm{Co}_{2}(\boldsymbol{L 1 2})_{4}(\mathrm{bpy})_{2}\right](\mathrm{DMF})_{6} \quad$ (figure $\left.12 \mathrm{~b}\right), \quad\left[\mathrm{Co}_{2}(\boldsymbol{L 1 2})_{4}(\mathrm{bpa})_{2}\right](\mathrm{DMF})_{8} \quad$ (figure 12 c) and $\left[\mathrm{Co}_{2}(\boldsymbol{L 1 2})_{4}(\text { bpe })_{2}\right](\mathrm{DMF})_{8}$ (figure $12 \mathrm{~d}$ ), presenting dimeric Co units bridged by carboxylate moieties $\left(\mathrm{d}_{\text {co. } 0 \mathrm{c}} c a .4 \AA\right)[31]$.

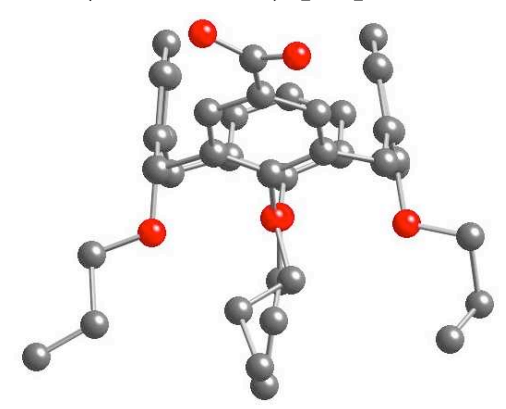

$L 12$

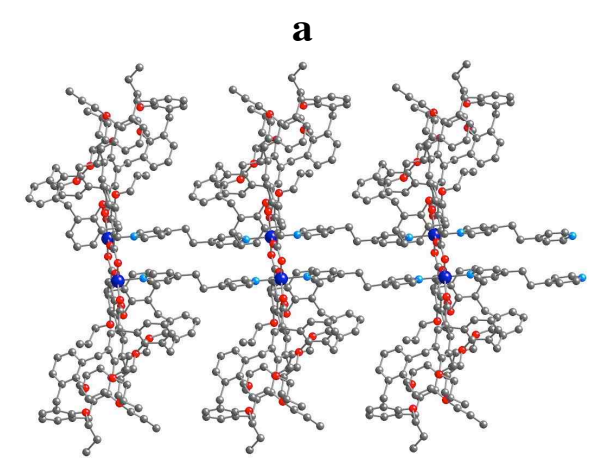

c

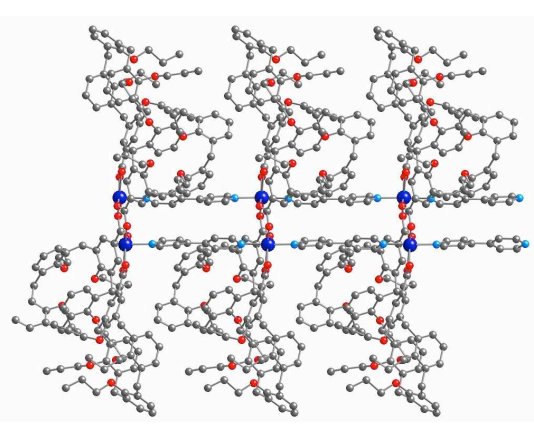

b

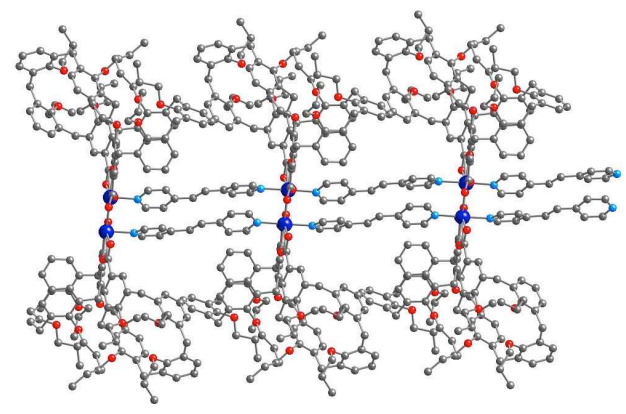

d

Figure 12: A portion of the X-ray structure showing the monosubstituted $p$-H-butoxycalix[4]arene $\boldsymbol{L 1 2}$ (a) in cone conformation, together with their corresponding isoreticular 1D Coordination Polymers

$\left[\mathrm{Co}_{2}(\boldsymbol{L 1 2})_{s}(\mathrm{bpy})_{2}\right](\mathrm{DMF})_{s}(\mathrm{~b}),\left[\mathrm{Co}_{2}(\boldsymbol{L 1 2})_{*}(\mathrm{bpa})_{2}\right](\mathrm{DMF})_{s}(\mathrm{c})$ and $\left[\mathrm{Co}_{2}(\boldsymbol{L 1 2})_{*}(\mathrm{bpe})_{2}\right](\mathrm{DMF})_{s}(\mathrm{~d})$. Dark-blue spheres represent Co atoms. $\mathrm{H}$ atoms and solvent molecules are not presented for sake of clarity. Adapted from Ref. [31]

\subsection{2 p-dicarboxylatocalixarene}

Several examples of supramolecular structures involving disubstituted calixarene held by non covalent bonds have been recently reported [32]. Here we focus only on the pure Coordination Polymers.

The reported examples are related to the disubstitution of the upper rim of classical tetrapropoxy $p$-H-calix[4]arene by very coordinating dicarboxylic acids ( $\boldsymbol{L 1 3}$ in cone conformation, figure 13 a), presented by Burrows et al. [33], leading, in solvothermal conditions, to new examples of MOFs, when combined with $\mathrm{Cu}$ (II), $\mathrm{Zn}$ (II), $\mathrm{Co}$ (II) or $\mathrm{Cd}$ (II) salts. Based on macrocyclic calixarenes that was obtained from oxidation of di-aldehyde with ozone, two or three dimensional porous, some of them being isostructural, systems were obtained with the following formula $\left[\mathrm{Co}_{5}(\boldsymbol{L 1 3})_{4}(\mathrm{OH})_{2}\left(\mathrm{H}_{2} \mathrm{O}\right)_{4}\right](\mathrm{DMF})_{8}(2 \mathrm{D}$, figure $13 \mathrm{~b})$ and 
$\left[\mathrm{M}_{2}(\boldsymbol{L 1 3})_{2}(\mathrm{DMF})_{2}\right](\mathrm{M}=\mathrm{Cu}$ or $\mathrm{Zn})(2 \mathrm{D}$, figure $13 \mathrm{c})$ and a $3 \mathrm{D}$ compound $\left[\mathrm{Cd}_{2}(\boldsymbol{L 1 3})_{2}(\mathrm{DMF})_{2}\right]$ $(\mathrm{DMF})_{3}$ (figure $13 \mathrm{~d}$ ). Porosity measurement of these systems were performed and analysed.

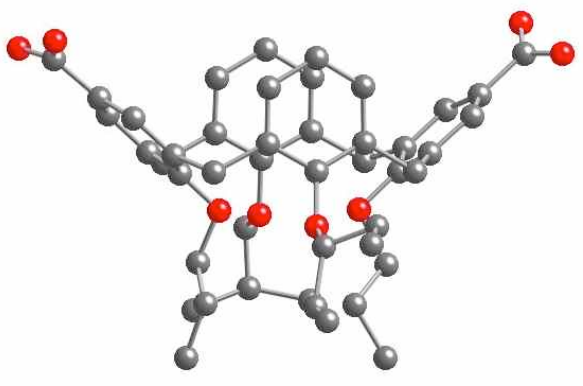

$L 13$

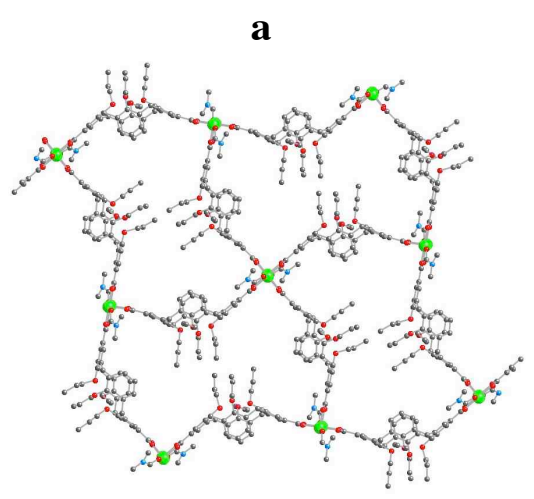

c

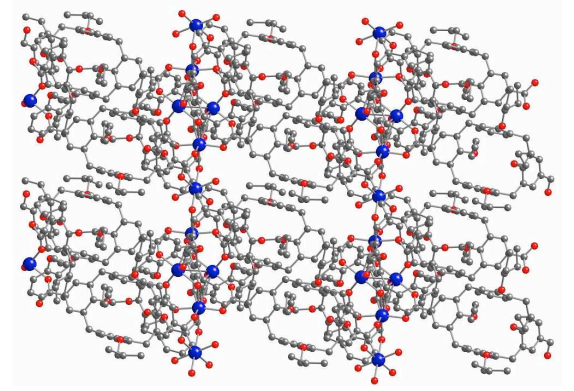

b

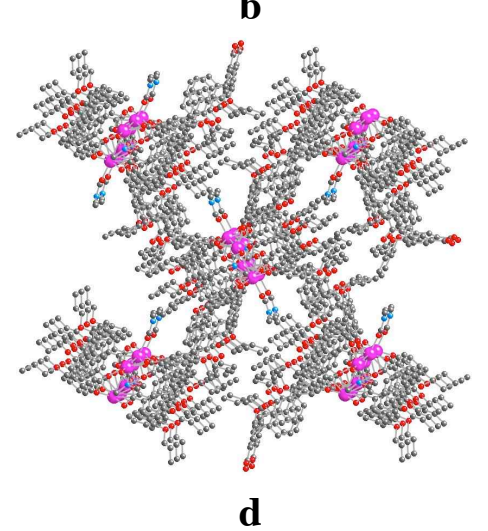

Figure 13: A portion of the X-ray structure showing the acid disubstituted tetrapropoxycalix[4]arene in cone conformation $\boldsymbol{L 1 3}$ (a) a 2D compound $\left[\mathrm{Co}_{s}(\boldsymbol{L 1 3})_{i}(\mathrm{OH})_{2}\left(\mathrm{H}_{2} \mathrm{O}\right)_{4}\right](\mathrm{DMF})_{\mathrm{s}}(\mathrm{b})$, a porous $2 \mathrm{D}$ compound $\left[\mathrm{M}_{2}(\boldsymbol{L 1 3})_{2}(\mathrm{DMF})_{2}\right](\mathrm{M}=\mathrm{Cu}$ or $\mathrm{Zn})(\mathrm{c})$ and a $3 \mathrm{D}$ compound $\left[\mathrm{Cd}_{2}(\boldsymbol{L 1 3})_{2}(\mathrm{DMF})_{2}\right](\mathrm{DMF}(\mathrm{d})$. Dark-blue, green and purplish-red spheres represent $\mathrm{Co}, \mathrm{Zn}(\mathrm{Cu})$ and $\mathrm{Cd}$ atoms, respectively. $\mathrm{H}$ atoms and solvent molecules are not presented for sake of clarity. Adapted from Ref. [33]

Using the phen ancillary ligand (see figure 8) and a disubstituted alkylated pdicarboxylatocalixarene L14, a 1D (double ribbon) compound of formula $\left[\mathrm{Cd}(\boldsymbol{L 1 4})(\right.$ phen $\left.)\left(\mathrm{H}_{2} \mathrm{O}\right)_{0.5}(\mathrm{DMF})_{0 .}\right]\left(\mathrm{H}_{2} \mathrm{O}\right)_{05}(\mathrm{DMF})_{0.5}$ (figure 14) was prepared by Dalgarno et al. [34].

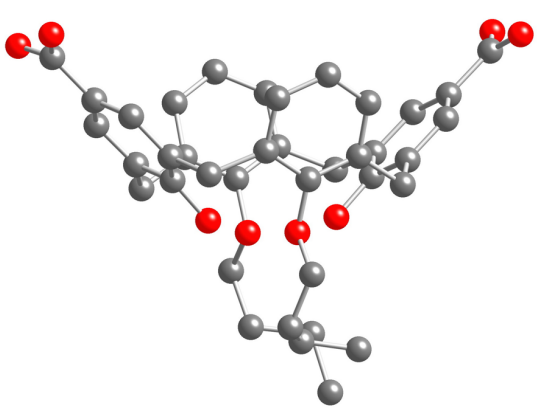

$L 14$

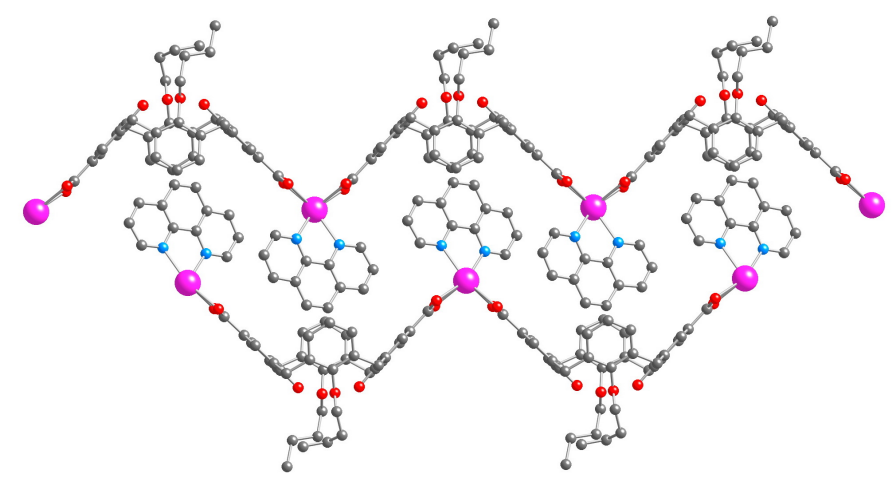

b

Figure 14: A portion of the X-ray structure showing (a) the used disubstituted alkylated pdicarboxylatocalixarene $\mathbf{L 1 4}$ in cone conformation and (b) the disubstituted alkylated p-dicarboxylatocalixarene

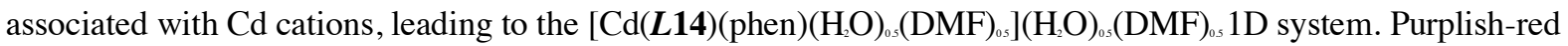
spheres represent $\mathrm{Cd}$ atoms. $\mathrm{H}$ atoms and solvent molecules are not presented for sake of clarity. Adapted from Ref. [34] 


\subsection{3 p-tetracarboxylato-Calix[4]arene}

A tetrasubstituted derivative ( $\mathbf{L 1 5}$, figure 15 a), blocked in 1,3-Alternate conformation was combined with $\mathrm{a} \mathrm{Rb}^{+}$salt which led to $1 \mathrm{D}$ Coordination Polymers (figure $15 \mathrm{~b}$ ). Supramolecular interaction in this compound leads to a porous complex 3D networks of formula $\left[\mathrm{Rb}_{5}\left(\mathrm{H}_{2} \mathrm{O}\right)_{16}(\boldsymbol{L 1 5})_{2}\right]\left(\mathrm{H}_{2} \mathrm{O}\right)_{4}[35]$.

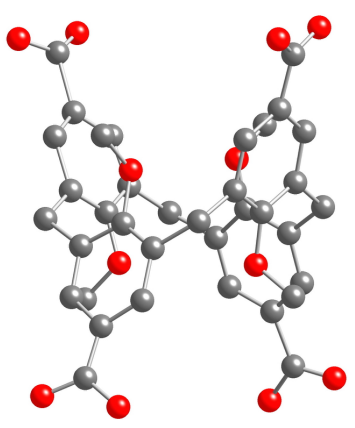

$L 15$

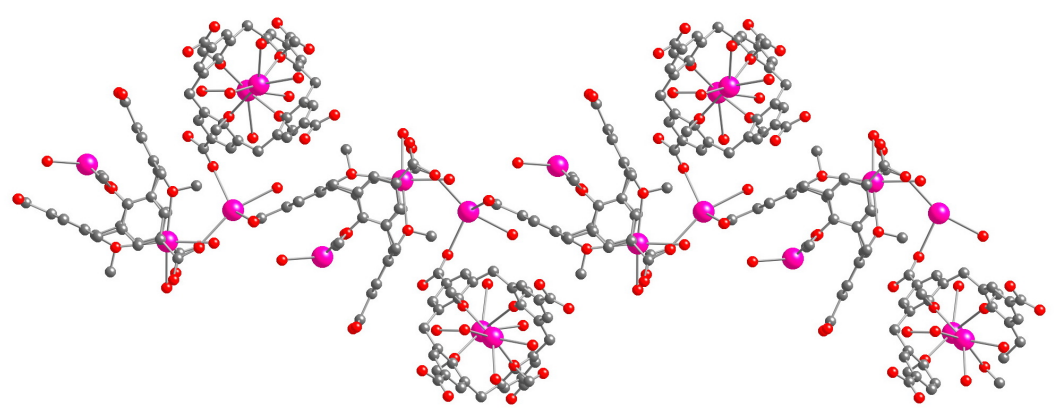

b

Figure 15: A portion of the X-ray structure showing the $p$-tetracarboxylato-calix[4]arene $\boldsymbol{L 1 5}$ in 1,3-Alternate conformation (a) and the resulting 1D Coordination Polymer of formula $\left[\mathrm{Rb}_{3}\left(\mathrm{H}_{2} \mathrm{O}\right)_{i s}(\boldsymbol{L 1 5})_{2}\right]\left(\mathrm{H}_{2} \mathrm{O}\right)_{4}$. (b). Pink spheres represent $\mathrm{Rb}$ atoms. $\mathrm{H}$ atoms and solvent molecules are not presented for sake of clarity. Adapted from Ref. [35]

\subsection{4 p-tetra m-(carboxyphenyl)-azocalix[4]arene}

Another examples of series of tetrasubstituted upper rim modification of the calixarene platform were given by Lang et al., with a tetrasubstituted carboxylate calix[4]arene ligand, in meta position of the azobenzene spacer, in cone conformation (L16 figure 16 a). The combination of this ligand with several lanthanides in the presence of acetic acid give rises to series of isomorphous 2D compounds of formula $\left[\mathrm{M}_{2} \mathrm{Cl}(\boldsymbol{L 1 6})(\mathrm{HCOO})(\mathrm{DMF})\right]_{3}(\mathrm{MeCN})_{0.5}$ $\left(\mathrm{H}_{2} \mathrm{O}\right)_{15}(\mathrm{M}=\mathrm{Nd}, \mathrm{Eu}$ and $\mathrm{Yb})$ (figure 16 b). $\left\{\left[\mathrm{H}_{3} \mathrm{O}\right]\left[\mathrm{M}(\boldsymbol{L 1 6})\left(\mathrm{H}_{2} \mathrm{O}\right)\right]_{3}(\mathrm{DMF})_{3}(\mathrm{MeCN})_{3} \mathrm{H}_{2} \mathrm{O}\right\}(\mathrm{M}=$ $\mathrm{Yb}, \mathrm{Eu}$ and $\mathrm{Y}$ ) (figure $16 \mathrm{c}$ ) [36]. When the same ligand is combined with $\mathrm{CdNO}_{3}$, it gives rise to a $3 \mathrm{D}$ polymer of formula $\left\{\left[\mathrm{H}_{3} \mathrm{O}\right]_{2}\left[\mathrm{Cd}(\boldsymbol{L 1 6})_{4}(\mathrm{DMF})_{4}(\mathrm{EtOH})_{2}\left(\mathrm{H}_{2} \mathrm{O}\right)_{2}\right](\mathrm{DMF})_{5}(\mathrm{EtOH})_{115} \mathrm{H}_{2} \mathrm{O}\right\}$ (figure $16 \mathrm{~d}$ ) [37].

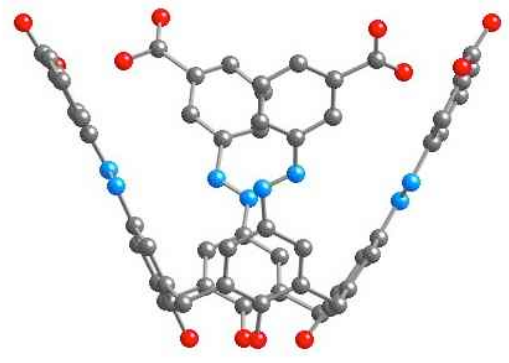

L16

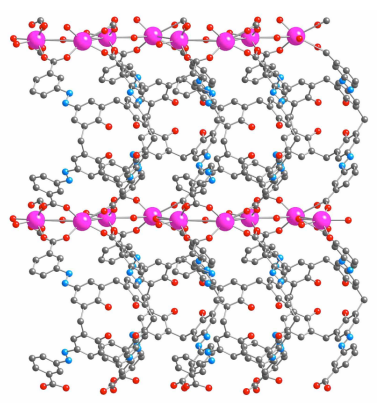

b 


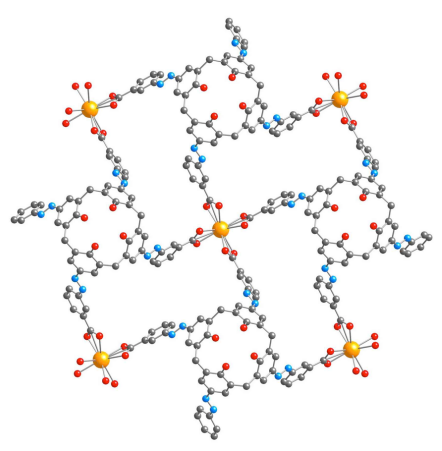

c

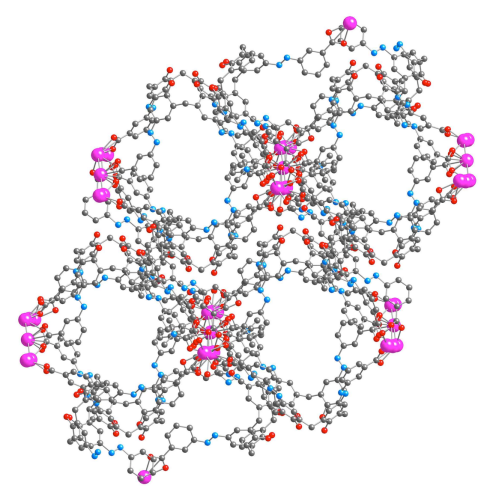

d

Figure 16: A portion of the X-ray structure showing the tetra ( $p$-carboxyphenyl)-azocalix[4]arene (L16) in cone conformation (a), the resulting 2D Coordination Polymer of formula $\left[\mathrm{M}_{2} \mathrm{Cl}(\boldsymbol{L 1 6})(\mathrm{HCOO})(\mathrm{DMF})\right]_{3}(\mathrm{MeCN})_{0.5}$ $\left(\mathrm{H}_{2} \mathrm{O}\right)_{15}(\mathrm{M}=\mathrm{Nd}, \mathrm{Eu}$ and $\mathrm{Yb})(\mathrm{b}),\left\{\left[\mathrm{H}_{3} \mathrm{O}\right]\left[\mathrm{M}(\boldsymbol{L 1 6})\left(\mathrm{H}_{2} \mathrm{O}\right)\right]_{3}(\mathrm{DMF})_{3}(\mathrm{MeCN})_{3} \mathrm{H}_{2} \mathrm{O}\right\}(\mathrm{M}=\mathrm{Yb}$, Eu and $\mathrm{Y})(\mathrm{c})$ and also a $3 \mathrm{D}$ Coordination Polymer of formula $\left\{\left[\mathrm{H}_{3} \mathrm{O}\right]_{2}\left[\mathrm{Cd}_{7}(\boldsymbol{L 1 6})_{4}(\mathrm{DMF})_{4}(\mathrm{EtOH})_{2}\left(\mathrm{H}_{2} \mathrm{O}\right)_{2}\right](\mathrm{DMF}) 5(\mathrm{EtOH})_{115} \mathrm{H}_{2} \mathrm{O}\right\}(\mathrm{d})$. Purplishred (or goldish yellow) spheres represent $\mathrm{Cd}$ (or Ln atoms) atoms. $\mathrm{H}$ atoms, solvent molecules and anions are not presented for sake of clarity. Adapted from Ref. [36-37]

\subsection{5 p-tetracyano-Calix[4]arene}

Another example of tetrasubstituted upper rim of classical calix[4]arene was also provided by Hosseini et al. [38], where the macrocycle in 1,3-Alternate conformation was decorated with coordinating cyano ( $\boldsymbol{L 1 7}$, figure 17 a), and, when combined with $\mathrm{Ag}^{+}$cations, it affords a linear non tubular Coordination Polymer with stoichiometry M/L equal to $1 / 1$, of formula $\left[\mathrm{AgAsF}_{6}(\boldsymbol{L 1 7})\right]\left(\mathrm{H}_{2} \mathrm{O}\right)_{2} \mathrm{C}_{2} \mathrm{H}_{5} \mathrm{OH}$ (figure 17 b). In this case, all the cyano groups appended at the upper rim of the 1,3-Alternate ligand are involved in the coordination with $\mathrm{Ag}^{+}$cations.

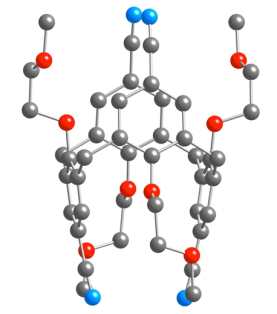

L17

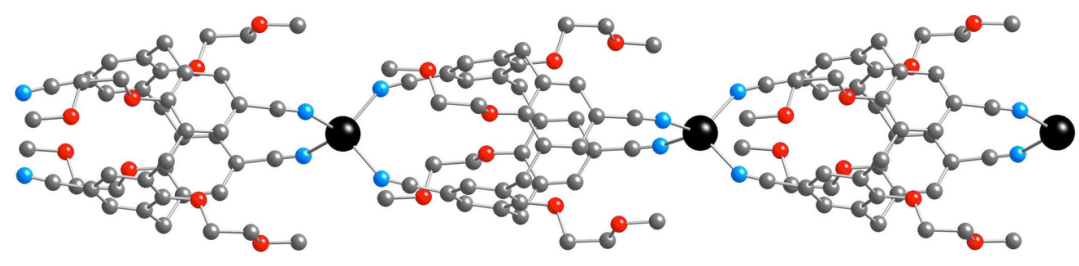

b

Figure 17: A portion of the X-ray structure showing the tetra- $p$-cyanocalix[4]arene $\mathbf{L 1 7}$ in 1,3-Alternate conformation (a) and the resulting 1D Coordination Polymer of formula $\left[\mathrm{AgAsF}_{6}(\boldsymbol{L 1 7})\right]\left(\mathrm{H}_{2} \mathrm{O}_{2} \mathrm{C}_{2} \mathrm{H}_{5} \mathrm{OH}\right.$ (b). Black spheres represent $\mathrm{Ag}$ atoms. $\mathrm{H}$ atoms, solvent molecules and anions are not presented for sake of clarity. Adapted from Ref. [38]

Up to now only the Coordination Polymers based on cyano or carboxylate calix[4]arene derivatives have been discussed.

The Coordination Polymers obtained using the highly coordinating $p$ sulfonatocalix[n]arene or $p$-phosphonatocalix[4]arene will be presented below.

\subsubsection{Sulfonatocalix[n]arene}


The upper rim functionalised $p$-sulfonatocalix[n]arene was used as ligand for the formation of extended structures. It is interesting to note that lots of networks using $p$ sulfonatocalix[4]arene $\mathbf{L 1 8}$ (figure 18, always in cone conformation), $p$ sulfonatocalix $[n]$ arene ( $\mathrm{n} \geq 5$, observed in different conformations) were reported.

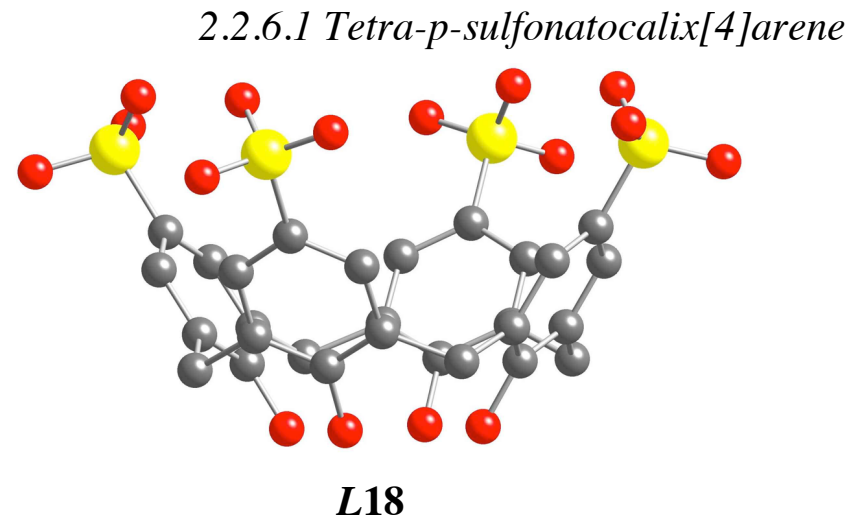

Figure 18: A portion of the X-ray structure of coordinating Tetra-p-sulfonatocalix[4]arene in cone conformation L18.

Tetra-p-sulfonatocalix[4]arene (L18), in cone conformation (figure 18), synthetically accessible due to reaction of direct sulfonation of p-Hcalix[4]arene or TCA, acts as a fourconnected node, and, as already said, is used very often to form Coordination Polymers, due to the multisite coordination groups, when combined with metals, lanthanides sometimes together with ancillary ligands. Different Coordination Polymers of various dimensionalities are shown below.

Raston et al. provided one of the first examples in 2001. This compound of formula $\left\{\left[\mathrm{Sc}_{2}(\mu-\mathrm{OH})_{2}\left(\mathrm{H}_{2} \mathrm{O}\right)_{8}\right]\left[\mathrm{Sc}\left(\mathrm{H}_{2} \mathrm{O}\right)_{4}\right]_{2}(\boldsymbol{L 1 8})_{2}\left([18] \text { crown-6)( } \mathrm{H}_{2} \mathrm{O}\right)_{16}\right\}$ (figure 19 a) presents a $2 \mathrm{D}$ structure encapsulating guest [18]crown-6 [39].

Several examples involving the well-known 2D grid of general formula $\left[\mathrm{M}^{\mathrm{m}}\left(\mathrm{H}_{2} \mathrm{O}\right)_{\mathrm{m}}(\boldsymbol{L 1 8})\right][40](\mathrm{M}=\mathrm{Gd}, \mathrm{Tb}, \mathrm{Tm})$ and lanthanide cations appeared in the literature, due to the $\mathrm{C} 4$ symmetry of the tetra- $p$-sulfonatocalix[4]arene, reporting the supramolecular encapsulation of different guests : $\left\{[2.2 .2]\right.$ cryptand $\subset\left[(\boldsymbol{L 1 8})_{2}\left(\mathrm{M}\left(\mathrm{H}_{2} \mathrm{O}\right)_{4}\right)_{3}\right\} \mathrm{M}=\mathrm{Ce}, \mathrm{Nd}, \mathrm{Sm}$ or Eu (figure 19 b), [41] (1,4-Diazabicyclo-[2.2.2] octane) $\subset\left[(\boldsymbol{L 1 8})_{4}\left(\mathrm{Nd}\left(\mathrm{H}_{2} \mathrm{O}\right)_{5}\right)\right]\left(\mathrm{H}_{2} \mathrm{O}\right)_{4}[42]$ or $\left(\mathrm{C}_{24} \mathrm{H}_{20} \mathrm{P}\right) \subset\left[(\boldsymbol{L 1 8}) \mathrm{Na}\left(\mathrm{H}_{2} \mathrm{O}\right)_{3} \mathrm{Yb}\left(\mathrm{H}_{2} \mathrm{O}\right)_{7}\right]\left(\mathrm{H}_{2} \mathrm{O}\right)_{4}[43]$. The use of uranyl nitrate in the presence of an ammonium or $\mathrm{Ce}$ salt also leads to the well-known 2D grid with the following formula $\left[\mathrm{NMe}_{4}\right]_{2} \subset\left[\mathrm{UO}_{2}(\boldsymbol{L 1 8})\right]\left(\mathrm{H}_{2} \mathrm{O}\right)_{0.5}$ (figure $19 \mathrm{~b}$ ), a similar arrangement was observed in the reported compound $\left[\mathrm{Ln}_{6}(\mathrm{OH})_{9}(\boldsymbol{L 1 8})_{2}\left(\mathrm{H}_{2} \mathrm{O}\right)\right](\mathrm{Ln}=\mathrm{La}, \mathrm{Pr}$ or $\mathrm{Nd}$ ) (figure $16 \mathrm{c})$ [44], for which the $\mathrm{Nd}$ compound presents an interesting selectivity towards $\mathrm{H}_{2}$ adsorption, as well as catalytic properties, and to a double layered compound of formula $\left[\mathrm{Ce}_{2}(\boldsymbol{L 1 8})\left(\mathrm{H}_{2} \mathrm{O}\right)_{15}\right]\left[\mathrm{UO}_{2}(\boldsymbol{L 1 8})\right]\left(\mathrm{H}_{2} \mathrm{O}\right)_{15}$ (figure $19 \mathrm{~d}$ ) [45].

Using the same ligand and different metal salt, a 3D compound of formula $\left[\left(\mathrm{M}\left(\mathrm{H}_{2} \mathrm{O}\right)_{4}\left(\mathrm{NO}_{3}\right)\right)\left(\mathrm{M}\left(\mathrm{H}_{2} \mathrm{O}\right)_{5}(\boldsymbol{L 1 8})\right]\left(\mathrm{H}_{2} \mathrm{O}\right)_{7}\right.$ with $\mathrm{M}=\mathrm{Pr}, \mathrm{Nd}$ and $\mathrm{Sm}$ was formed (figure $19 \mathrm{e}$ ) [46]. 


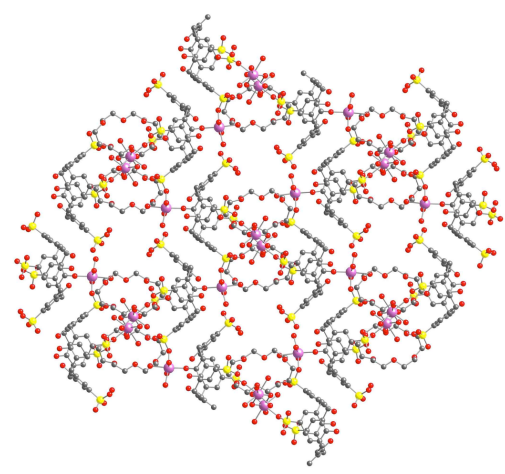

$\mathbf{a}$

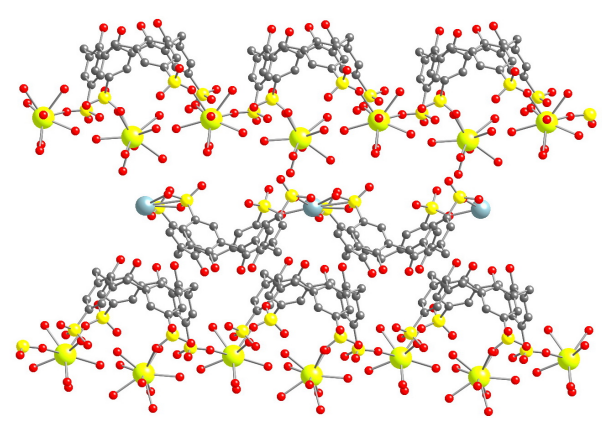

d

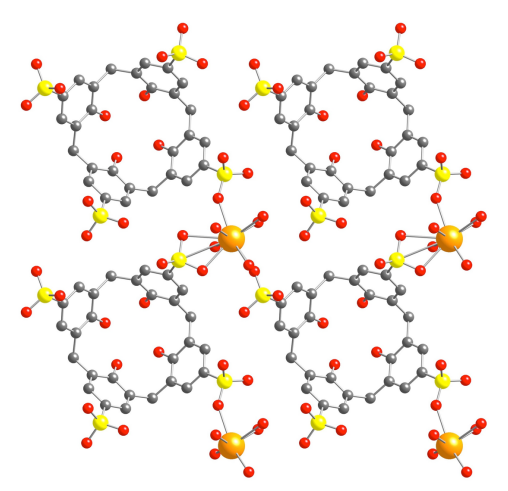

b

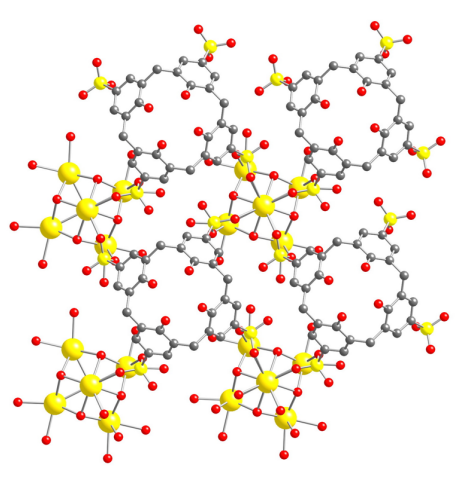

C

Figure 19: A portion of the X-ray structure showing Coordination Polymers based on tetra-psulfonatocalix[4]arene (L18, figure 18): the 2D Coordination Polymer $\left\{\left[\mathrm{Sc}_{2}(\mu\right.\right.$ -

$\left.\left.\mathrm{OH})_{2}\left(\mathrm{H}_{2} \mathrm{O}\right)_{8}\right]\left[\mathrm{Sc}\left(\mathrm{H}_{2} \mathrm{O}\right)_{4}\right]_{2}(\boldsymbol{L 1 8})_{2}\left([18] \text { crown-6)( } \mathrm{H}_{2} \mathrm{O}\right)_{16}\right\}$ (a), the well- known 2D system of formula $\left[\mathrm{M}^{\mathrm{m}}\left(\mathrm{H}_{2} \mathrm{O}\right)_{\mathrm{m}}(\boldsymbol{L 1 8})\right]$ $(\mathrm{M}=\mathrm{Ce}, \mathrm{Nd}, \mathrm{Sm}, \mathrm{Eu})(\mathrm{b})$, its analogues $\left[\mathrm{Ln}_{\odot}(\mathrm{OH})_{,}(\mathbf{L 1 8})_{2}\left(\mathrm{H}_{2} \mathrm{O}\right)_{v}\right](\mathrm{Ln}=\mathrm{La}, \mathrm{Pr}$ or Nd) (c)

$\left[\mathrm{Ce}_{2}(\boldsymbol{L 1 8})\left(\mathrm{H}_{2} \mathrm{O}\right)_{15}\right]\left[\mathrm{UO}_{2}(\boldsymbol{L 1 8})\right]\left(\mathrm{H}_{2} \mathrm{O}\right)_{15}(\mathrm{~d})$ and the $3 \mathrm{D}$ compound $\left[\left(\mathrm{M}\left(\mathrm{H}_{2} \mathrm{O}\right)_{4}\left(\mathrm{NO}_{3}\right)\right)\left(\mathrm{M}_{(}\left(\mathrm{H}_{2} \mathrm{O}\right)_{s}(\boldsymbol{L 1 8})\right]\left(\mathrm{H}_{2} \mathrm{O}\right)_{7}(\mathrm{M}=\mathrm{Pr}, \mathrm{Nd}\right.$ and Sm) (e). Light violet, goldish yellow (or yellow) and light blue spheres represent Sc, Ln (all kind) and U atoms, respectively. $\mathrm{H}$ atoms, solvent molecules and guest molecules are not presented for sake of clarity.

Adapted from Ref. [39-46]

Other examples of Coordination Polymers involving ancillary ligands and lanthanides cations were given more recently by Liu et al. Two 3D porous compounds, based on the use of bistriazolyl ligands were reported, with respective formula $\left[\mathrm{Cu}_{2}(\mathrm{btb})_{35}(\boldsymbol{L 1 8})\left(\mathrm{H}_{2} \mathrm{O}\right)\right]_{3}\left(\mathrm{H}_{2} \mathrm{O}\right)_{25}$ (btb=1,4-bis(1,2,4-triazol-1-yl)butane and $\mathrm{htz}=1,3,4$-triazolate) (figure 20 a) and $\left[\mathrm{Cu}_{25}(\text { btp })_{2}(\boldsymbol{L 1 8})(\mathrm{htz})\left(\mathrm{H}_{2} \mathrm{O}\right)_{3}\right]_{3}\left(\mathrm{H}_{2} \mathrm{O}\right)_{475}$ (btp= 1,4-bis $(1,2,4$-triazol-1-yl)pentane and htz $=1,3,4-$ triazolate) (figure $20 \mathrm{~b}$ ) [47].

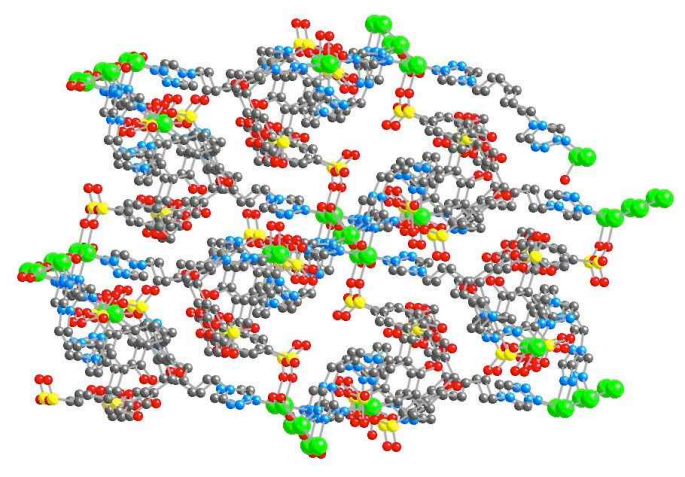

$\mathbf{a}$

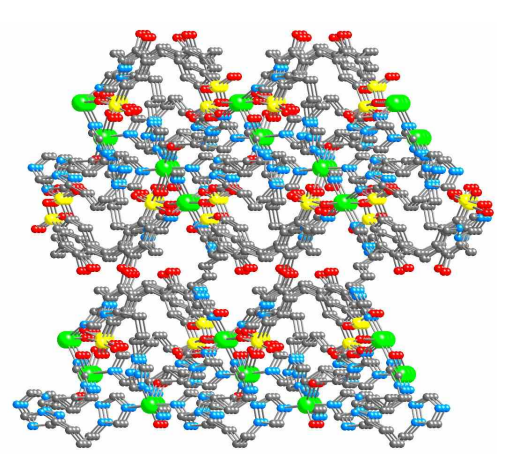

b 
Figure 20: A portion of the X-ray structure showing the initial system based on tetra- $p$-sulfonatocalix[4]arene (L17, figure 18), the 3D Coordination Polymers: $\left[\mathrm{Cu}_{2}(\mathrm{btb})_{3 s}(\boldsymbol{L 1 7})\left(\mathrm{H}_{2} \mathrm{O}\right)\right]_{3}\left(\mathrm{H}_{2} \mathrm{O}\right)_{25}(\mathrm{btb}=1,4-\mathrm{bis}(1,2,4$-triazol-1yl)butane and htz $=1,3,4-$ triazolate) (a) and $\left[\mathrm{Cu}_{25}(\mathrm{btp})_{2}(\boldsymbol{L 1 7})(\mathrm{htz})\left(\mathrm{H}_{2} \mathrm{O}\right)_{3}\right]_{3}\left(\mathrm{H}_{2} \mathrm{O}\right)_{475}(\mathrm{btp}=1,4-$ bis $(1,2,4$-triazol-1yl)pentane) (b). Green spheres represent $\mathrm{Cu}$ atoms. H atoms and solvent molecules are not presented for sake of clarity. Adapted from Ref. [47]

Zhang et al. also reported a perfect 2D system based on the use of the pillar ligand 1,10-phenanthroline (phen, see figure 8), presenting in the coordination sphere of the metal embedded in the Coordination Polymer giving rise to formula $\left[\mathrm{MLn}(\mathrm{phen})_{2}(\boldsymbol{L 1 8}) \mathrm{H}_{2} \mathrm{O}\right]$ where $\mathrm{Ln}=\mathrm{Nd}$ or $\mathrm{Eu}, \mathrm{M}=\left(\mathrm{CH}_{3}\right)_{4} \mathrm{~N}^{+}$or $\left(\mathrm{C}_{2} \mathrm{H}_{5}\right)_{4} \mathrm{~N}^{+}$(figure 21 a) [48]. This cationic Coordination Polymer contains also encapsulating tetra-alkylated amines. Using also 4,4'-bipyridine-N,N'dioxide as ancillary (bpy-N-ox) ligands, a 1D Coordination Polymer of formula $\left[\mathrm{Nd}_{2}(\mathrm{bpy}-\mathrm{N}-\right.$ ox $)_{2}(\boldsymbol{L 1 8})\left(\mathrm{NO}_{3}\right)\left(\mathrm{H}_{2} \mathrm{O}\right)_{9}$ ] was also reported (figure 21 b) [49]. Using ethylenediamine (en), a 1D system of formula (en $)_{05}\left[\left\{\mathrm{Ag}_{2}(\mathrm{en})_{2}\right\}\left\{\mathrm{Ag}_{4}(\mathrm{en})_{4}\right\}_{2}(\boldsymbol{L 1 8})_{2}\right]\left(\mathrm{H}_{2} \mathrm{O}\right)_{17}$ including a 20 membered macrocycle, was reported (figure $21 \mathrm{c}$ ) [50].

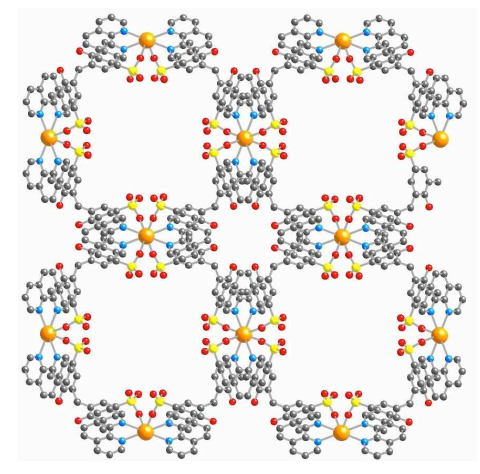

a

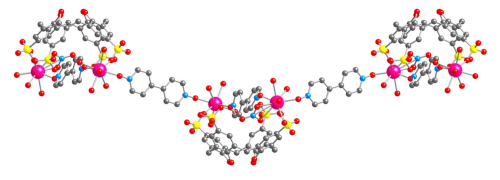

b

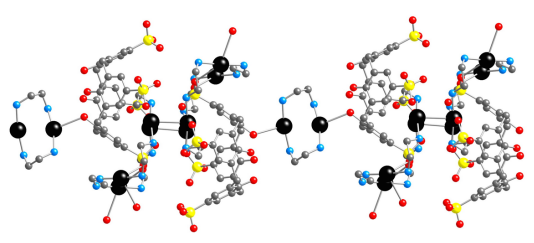

c

Figure 21: A portion of the X-ray structure showing the initial system based on tetra-p-sulfonatocalix [4]arene (L18, figure 17) and $\mathrm{N}$ donor ancillary ligands: the $2 \mathrm{D}\left[\mathrm{MLn}(\text { phen })_{2}(\boldsymbol{L 1 8}) \mathrm{H}_{2} \mathrm{O}\right]\left(\mathrm{Ln}=\mathrm{Nd}\right.$ or Eu, $\mathrm{M}=\left(\mathrm{CH}_{3}\right)_{4} \mathrm{~N}^{*}$ or

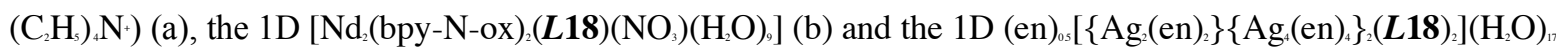

(c). Goldish yellow, purplish-red and black spheres represent $\mathrm{Eu}, \mathrm{Nd}$ and $\mathrm{Ag}$ atoms, respectively. $\mathrm{H}$ atoms, solvent molecules and cations are not presented for sake of clarity. Adapted from Ref. [48-50]

\subsubsection{Tetra-p-sulfonatothiacalix[4]arene}

The upper rim of thiacalixarene was also sulfonated as its calixarene analogue to give the $p$-sulfonatothiacalix[4]arene (L19, figure 22 a). In that case, the sulphur atoms present in the ring of the macrocyle may also participate in coordination with soft metals. Then it was combined with metals (and sometimes other ligands) in order to obtain Coordination Polymers.

Hong et al. reported two analogous 2D systems based on tetranuclear copper(II) clusters and L19, including organic and inorganic guests through supramolecular interactions : $\left\{\left[\mathrm{M}(2,2-\mathrm{bpz})\left(\mathrm{H}_{2} \mathrm{O}\right)_{4}\right]\left[\mathrm{M}_{4}(\boldsymbol{L 1 9})\left(\mu_{4}-\mathrm{SO}_{4}\right)\left(\mathrm{H}_{2} \mathrm{O}\right)_{4}\right]\left(\mathrm{H}_{2} \mathrm{O}\right)_{\mathrm{m}}\right\} \quad(\mathrm{M}=\mathrm{Co}$ or $\mathrm{Cu}, 2,2-$ bpz=2,2'-bipyrazine) [51] (figure $22 \mathrm{~b}$ ) and $\left\{\left[\mathrm{PhCH}_{2} \mathrm{~N}\left(\mathrm{CH}_{3}\right)_{3}\right]\left[\mathrm{M}_{4}(\boldsymbol{L 1 9})\left(\mu_{4}-\mathrm{SO}_{4}\right)\left(\mathrm{H}_{2} \mathrm{O}\right)_{4}\right]\left(\mathrm{H}_{2} \mathrm{O}\right)_{\mathrm{m}}\right\}$ $(\mathrm{M}=\mathrm{Co}$ or $\mathrm{Cu}$ ) (figure $22 \mathrm{c}$ ) [52]. The same connectivity of $p$-sulfonatothiacalix[4]arene including pyridinium cation has also been described [53].

Hamada et al. also reported a 3D Coordination Polymers of formulas 
$\left[\mathrm{Na}_{2} \mathrm{~K}_{4}\left(\boldsymbol{L}\right.\right.$ 19) $\left.(\text { pyNO})_{7}\left(\mathrm{H}_{2} \mathrm{O}\right)\right] \quad[54]$ (pyNO $=$ pyridine $\mathrm{N}$-oxide) (figure 21 d) and $\left.\left[\mathrm{Na}_{2} \mathrm{~K}_{4}(\boldsymbol{L 1 9})\right]\left(\mathrm{H}_{2} \mathrm{O}\right)_{7}\right]$ (figure $\left.22 \mathrm{e}\right)$ [55]. It was shown that the latest presents some affinities for $\mathrm{CO}_{2}$ adsorption.

A 1D compound of formula $\left[\mathrm{Cu}\left(\mathrm{H}_{2} \mathrm{O}\right)_{6}\right]\left[\mathrm{Cu}_{2}(\boldsymbol{L 1 9})\left(\mu-2,2^{\prime}\right.\right.$-bpno $\left.)\left(\mathrm{H}_{2} \mathrm{O}\right)_{3}\right]\left(\mathrm{H}_{2} \mathrm{O}\right)_{10} \quad\left(2,2^{\prime}-\right.$ bpno = 2,2' -bipyridine-1,10 dioxide) (figure $22 \mathrm{f}$ ) was also reported, together with its magnetic and luminescent properties, that was caused by the presence of $\mathrm{Cu}$ (II) cations [56].

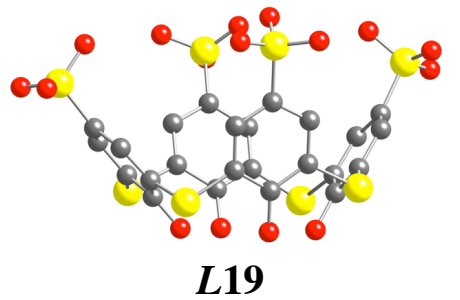

$\mathbf{a}$

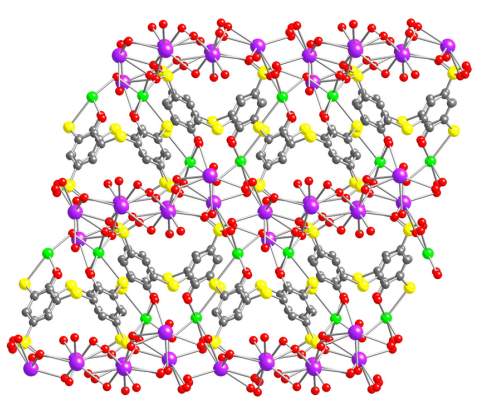

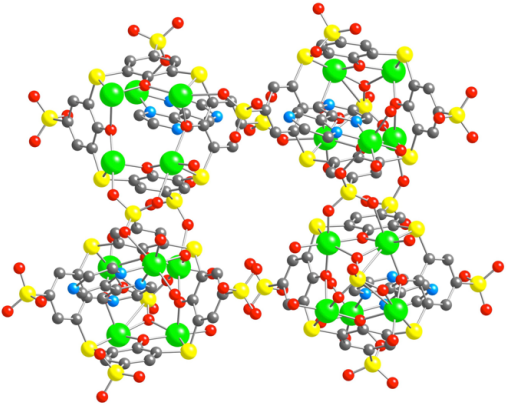

b

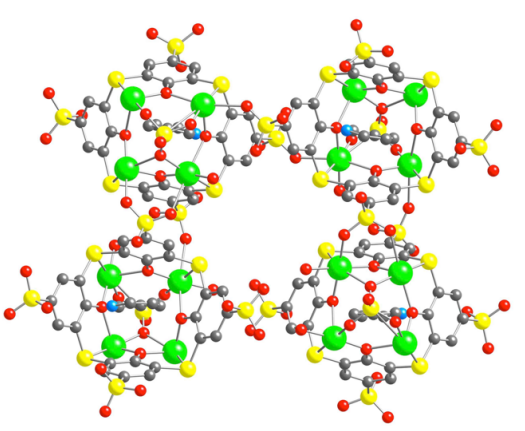

c

d

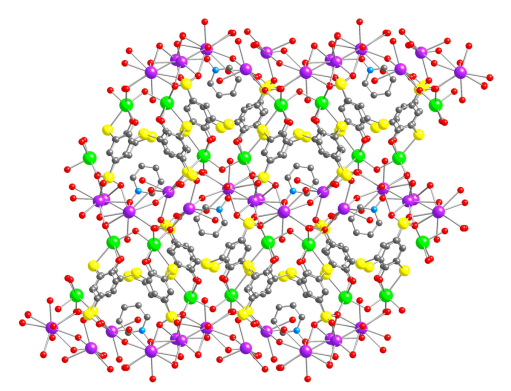
e

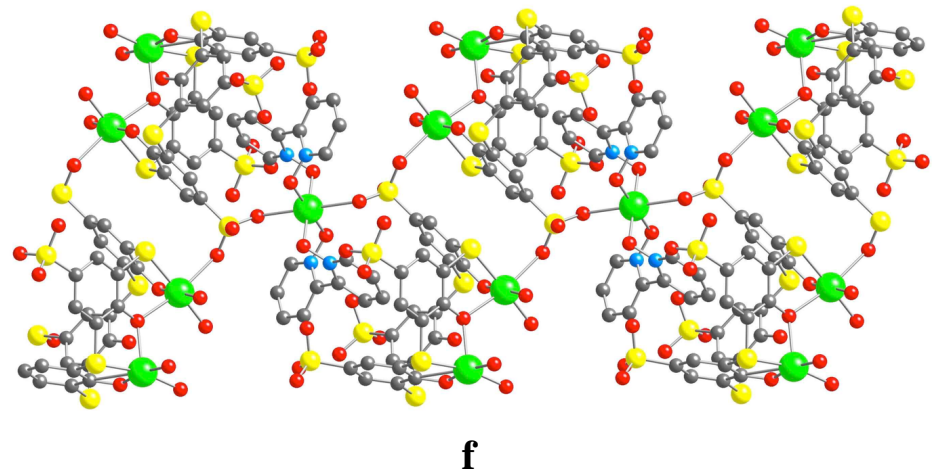

Figure 22: A portion of the X-ray structure showing the initial system based on tetra- $p$-sulfonatothiacalix[4]arene $\boldsymbol{L 1 9}$ (a), 2D Coordination Polymers $\left\{\left[\mathrm{M}(2,2-\mathrm{bpz})\left(\mathrm{H}_{2} \mathrm{O}\right)_{4}\right]\left[\mathrm{M}(\boldsymbol{L 1 9})\left(\mu_{-}-\mathrm{SO}_{4}\right)\left(\mathrm{H}_{2} \mathrm{O}\right)_{4}\right]\left(\mathrm{H}_{2} \mathrm{O}\right)_{\mathrm{m}}\right\}(\mathrm{M}=\mathrm{Co}$ or $\mathrm{Cu}, 2,2-$ bpz=2,2'-bipyrazine) (b) and $\left\{\left[\mathrm{PhCH}_{2} \mathrm{~N}\left(\mathrm{CH}_{3}\right)_{3}\right]\left[\mathrm{M}_{4}(\boldsymbol{L 1 9})\left(\mu_{-}-\mathrm{SO}_{*}\right)\left(\mathrm{H}_{2} \mathrm{O}\right)_{4}\right]\left(\mathrm{H}_{2} \mathrm{O}\right)_{\mathrm{m}}\right\}(\mathrm{M}=\mathrm{Co}$ or $\mathrm{Cu})(\mathrm{c})$, the 3D $\left[\mathrm{Na}_{2} \mathrm{~K}_{4}(\boldsymbol{L 1 9}) \mathrm{H}_{2} \mathrm{O}\right](\mathrm{d})$, the $3 \mathrm{D}$ Coordination Polymer $\left[\mathrm{Na}_{2} \mathrm{~K}_{(}(\boldsymbol{L 1 9})(\mathrm{pyNO})\left(\mathrm{H}_{2} \mathrm{O}\right)\right]($ pyNO $=$ pyridine $\mathrm{N}$-oxide $)($ e) and the 1D compound of formula $\left[\mathrm{Cu}\left(\mathrm{H}_{2} \mathrm{O}\right)_{6}\right]\left[\mathrm{Cu}_{2}(\boldsymbol{L 1 9})\left(\mu-2,2^{\prime}-\right.\right.$ bpno $\left.)\left(\mathrm{H}_{2} \mathrm{O}\right)_{3}\right]\left(\mathrm{H}_{2} \mathrm{O}\right)_{1}\left(2,2^{\prime}\right.$-bpno $=2,2^{\prime}$ '-bipyridine1,10 dioxide) (f). Green, purplish-red and light-green spheres represent $\mathrm{Cu}$ (or $\mathrm{Co}$ ), $\mathrm{K}$ and $\mathrm{Na}$ atoms, respectively. $\mathrm{H}$ atoms and solvent molecules are not presented for sake of clarity. Adapted from Ref. [51-55] 
Calix[5] arene and in particular even penta- $p$-sulfonatocalix[5] arene (L20, figure 23 a) is a relative rare building block for the formation of high dimensional molecular networks. The ligand usually exhibits a cone conformation.

The first example was reported by Raston et al., with the formation of a 1D system of

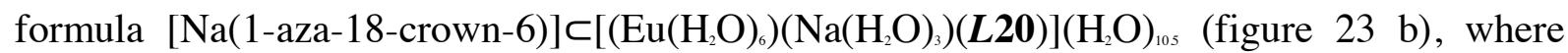
the 1D anionic Coordination Polymer is hosting the [(Na(1-aza-18-crown-6) $)]^{+}$units, through supramolecular interactions [57]. A similar Gd(III) based 1D Coordination Polymer has been recently reported, including [3-(2-hydroxyethyl)-1-methylimidazolium] cation, as shown in figure $23 \mathrm{c}$ [58].

The first 2D compound with $p$-sulfonatocalix[5]arene was reported by Makha et al., involving the coordination of ytterbium/sodium atoms, with the formula $\left[\mathrm{Na}\left(\mathrm{H}_{2} \mathrm{O}\right)_{4}(\boldsymbol{L 2 0}) \mathrm{Yb}\right.$ $\left.\left(\mathrm{H}_{2} \mathrm{O}\right)_{7}\right]_{2}\left(\mathrm{H}_{2} \mathrm{O}\right)_{11}$ consisting in a compact and discrete bilayer arrangement formed through bridging of the sulfonate groups by ytterbium and sodium cations with increased bilayer thickness (figure $23 \mathrm{~d}$ ) [59].

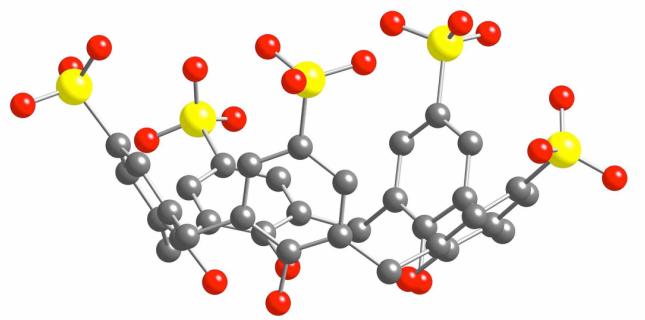

L20

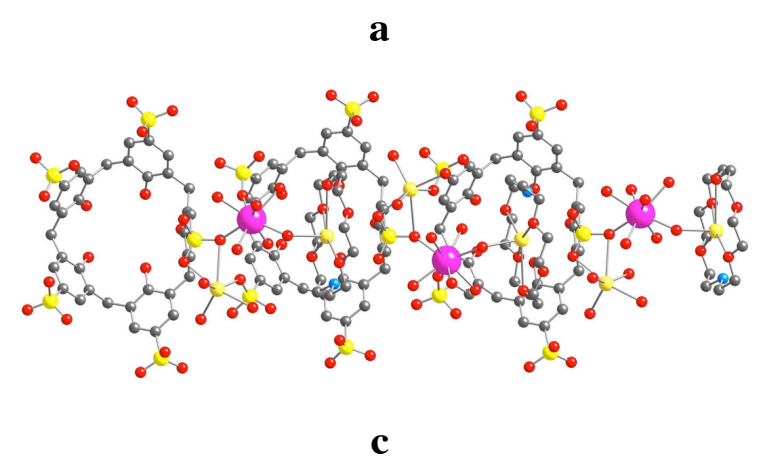

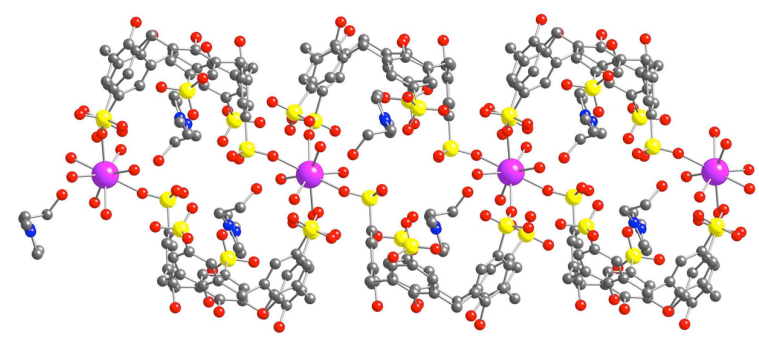

b

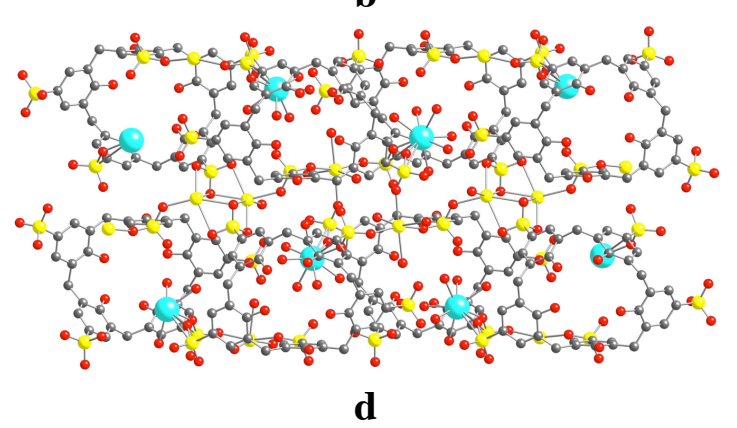

Figure 23: A portion of the X-ray structure showing $p$-sulfonatothiacalix[5]arene $\boldsymbol{L 2 0}$ (a), 1D Coordination Polymer [3-(2-hydroxyethyl)-1-methylimidazolium] $\subset\left[\left(\mathrm{Gd}\left(\mathrm{H}_{2} \mathrm{O}\right)_{6}\right)\left(\mathrm{Na}\left(\mathrm{H}_{2} \mathrm{O}\right)_{3}\right)(\boldsymbol{L 2 0})\right]$ (b), [Na(1-aza-18-crown-

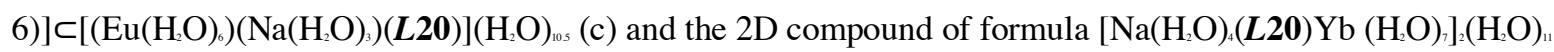
(d). Purplish-red and light-blue spheres represent $\mathrm{Gd}$, and $\mathrm{Yb}$ atoms, respectively. $\mathrm{H}$ and $\mathrm{Na}$ atoms and solvent molecules are not presented for sake of clarity. Adapted from Ref. [57-59]

By increasing phenolic fragments in calixarene backbone, this leads to an increase of the flexibility of the macrocyclic ligand.

\subsubsection{Hexa-p-sulfonatocalix[6]arene}

In contrast to $p$-sulfonatocalix[4]arene, $p$-sulfonatocalix[6]arene (L21, figure 24 a), when deprotonated, is a more highly charged (-6) and conformationally flexible molecule, which strongly influences solid-state complex formation and for those reasons very few Coordination Polymers based on $p$-sulfonatocalix[6]arene are reported till now. The first example was reported by Raston et al., where $p$-sulfonatocalix[6]arene adopts a partial cone 
conformation, is a 1D zigzag Coordination Polymer of formula $\left[\left(\mathrm{Eu}\left(\mathrm{H}_{2} \mathrm{O}\right)_{6}\right)_{2}(\mathrm{bpy}-\mathrm{N}-\right.$ ox $)(\boldsymbol{L 2 1})]\left(\mathrm{H}_{2} \mathrm{O}\right)_{8}($ bpy-N-ox=4,4'-bipyridine-N,N'-dioxide) containing also an ancillary ligand (figure 24 b) [60]. In the latter case, the macrocycle adopts a double partial cone conformation.

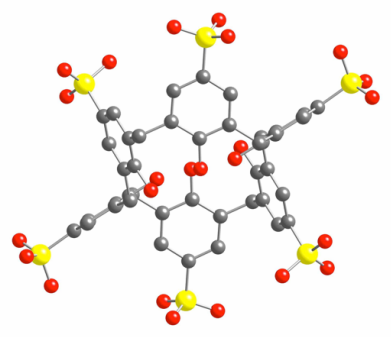

L21

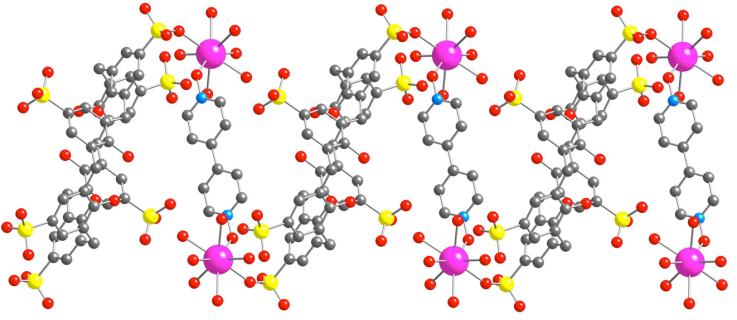

b

Figure 24: A portion of the X-ray structure showing $p$-sulfonatocalix[6]arene $\mathbf{L 2 1}$ in double partial cone conformation (a) and the resulting 1D Coordination Polymer $\left[\left(\mathrm{Eu}\left(\mathrm{H}_{2} \mathrm{O}_{6}\right)_{2}(\mathrm{bpy}-\mathrm{N}-\mathrm{ox})(\boldsymbol{L 2 1})\right]\left(\mathrm{H}_{2} \mathrm{O}\right)_{s}\right.$ (b). Purplishred spheres represent $\mathrm{Eu}$ atoms. $\mathrm{H}$ atoms, solvent molecules and anions are not presented for sake of clarity.

Adapted from Ref. [60]

More recently, series of Coordination Polymers were reported by Zhang et al. [61], involving the use of the $p$-sulfonatocalix[6] arene $\mathbf{L 2 2}$ in partial cone conformation (figure 25 a) and the use of ancillary $\mathrm{N}$ donor ligands like imidazole (Imz) and 1,10-phenanthroline (phen, figure 8). The combination with transition metal ions leads to the formation of Coordination Polymers of different dimensionalities: 1D of formula $\left\{\left[\mathrm{Cu}(\mathrm{Imz})_{2}(\text { phen })\right]_{2}\left[\mathrm{Cu}(\mathrm{Imz})(\text { phen })\left(\mathrm{H}_{2} \mathrm{O}\right)_{2}\right]_{2}(\boldsymbol{L 2 2})_{3}\left(\mathrm{H}_{2} \mathrm{O}\right)_{133}\right\}$ (figure $25 \mathrm{~b}$ ) or two isostructural 1D of general formula $\left\{\left[\mathrm{M}(\mathrm{phen})_{2}\left(\mathrm{H}_{2} \mathrm{O}\right)\right]\left[\mathrm{M}(\mathrm{phen})_{2}\right]_{2}(\boldsymbol{L 2 2})\right\}_{3}\left(\mathrm{H}_{2} \mathrm{O}\right)_{\mathrm{n}}(\mathrm{M}=\mathrm{Co}$ or $\mathrm{Zn})$ (figure $25 \mathrm{c}$ ) and a 2D compound of formula $\left\{\left[\mathrm{Cu}(\mathrm{Imz})(\text { phen })\left(\mathrm{H}_{2} \mathrm{O}\right)\right]_{4}(\boldsymbol{L 2 2})_{3}\left(\mathrm{H}_{2} \mathrm{O}\right)_{10}\right\}$ (figure $25 \mathrm{~d}$ ). In all the cases, the macrocycle adopts a 1,2,3-alternate conformation (partial cone).

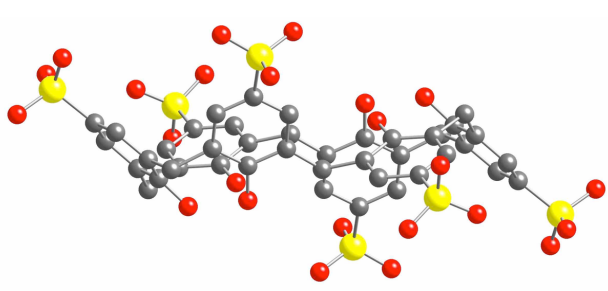

L22

a

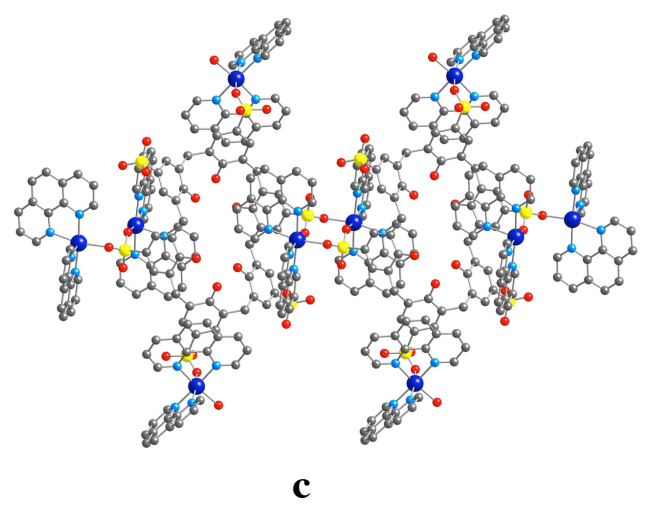

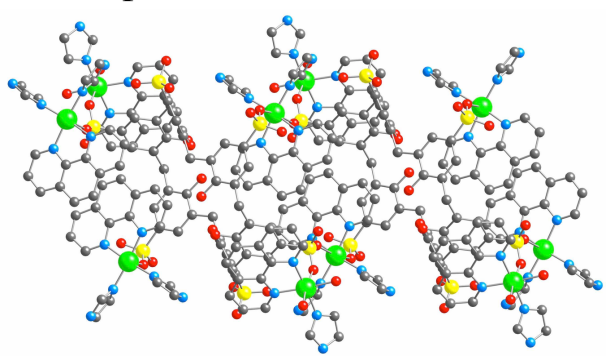

b

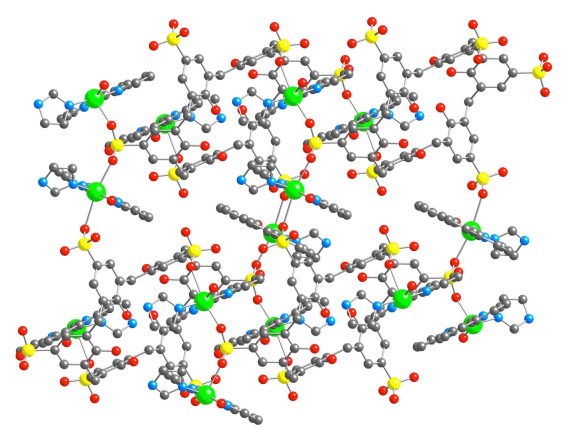

d

Figure 25: A portion of the X-ray structure showing $p$-sulfonatocalix[6]arene $\boldsymbol{L 2 2}$ in 1,2,3-alternate conformation (a), the resulting 1D Coordination Polymer 
$\left\{\left[\mathrm{Cu}(\operatorname{Imz})_{2}(\mathrm{phen})\right]_{2}\left[\mathrm{Cu}(\operatorname{Imz})(\text { phen })\left(\mathrm{H}_{2} \mathrm{O}\right)_{2}\right]_{2}(\boldsymbol{L 2 2 2})_{2}\left(\mathrm{H}_{2} \mathrm{O}\right)_{\mathrm{B} 3}\right\}(\mathrm{b})$, one of the two isomorphous $\left\{\left[\mathrm{M}(\mathrm{phen})_{2}\left(\mathrm{H}_{2} \mathrm{O}\right)\right]\left[\mathrm{M}(\mathrm{phen})_{2_{2}}\right]_{2}(\boldsymbol{L 2 2})\right\}_{3}\left(\mathrm{H}_{2} \mathrm{O}\right)_{n}(\mathrm{M}=\mathrm{Co}$ or $\mathrm{Zn})(\mathrm{c})$ and the $2 \mathrm{D}$ system $\left\{\left[\mathrm{Cu}(\mathrm{Imz})(\text { phen })\left(\mathrm{H}_{2} \mathrm{O}\right)\right]_{(}(\boldsymbol{L 2 2})_{3}\left(\mathrm{H}_{2} \mathrm{O}\right)_{10}\right\}$ (d). Green and dark-blue spheres represent $\mathrm{Cu}$, and $\mathrm{Co}$ (or $\left.\mathrm{Zn}\right)$ atoms, respectively. $\mathrm{H}$ atoms and solvent molecules are not presented for sake of clarity. Adapted from Ref. [61]

\subsubsection{Hexa-p-sulfonatothiacalix[6]arene}

The 1,2,3-alternate conformation of $p$-sulfonatothiacalix[6] arene ( $\mathbf{L 2 3}$, figure 26 a) has also been observed in a series of 1D «ladder-type» compounds of general formula: $\left[\left\{\mathrm{Ln}\left(\mathrm{H}_{2} \mathrm{O}\right)_{7}\right\}_{2}(\boldsymbol{L 2 6})\right]\left(\mathrm{H}_{2} \mathrm{O}\right)_{13}$, where $\mathrm{Ln}=\mathrm{La}$ or $\mathrm{Ce}$ (figure 26 b) [62]. In that case no participation of the $\mathrm{S}$ atom of the macrocyclic ring of the TCA is observed.

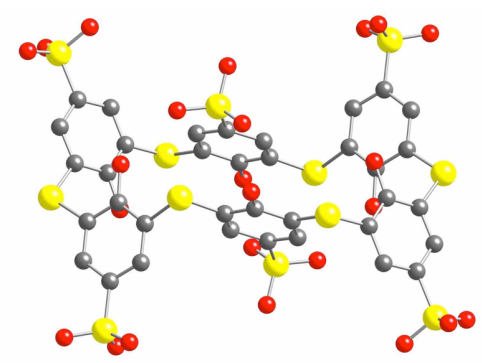

$L 23$

a

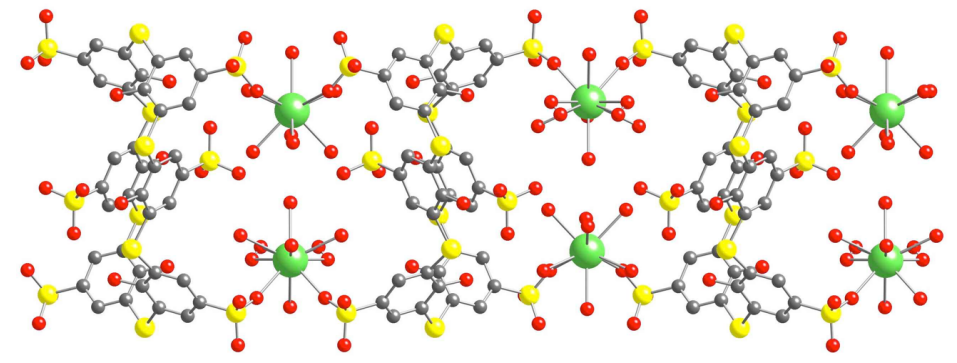

b

Figure 26: A portion of the X-ray structure showing $p$-sulfonatothiacalix[6]arene $\boldsymbol{L 2 3}$ in 1,2,3-alternate conformation (a) and the resulting 1D Coordination Polymer $\left[\left\{\mathrm{Ln}\left(\mathrm{H}_{2} \mathrm{O}\right)_{)_{2}}\right\}_{2}(\boldsymbol{L 2 3})\right]\left(\mathrm{H}_{2} \mathrm{O}\right)_{\mathrm{s}}(\mathrm{M}=\mathrm{La}$ or Ce) (b). $\mathrm{H}$ atoms, solvent molecules and anions are not presented for sake of clarity. Green spheres represent Ln atoms. Adapted from Ref. [62]

\subsubsection{Hepta-p-sulfonatocalix[7]arene}

The first solid state extended coordination structure of even $p$-sulfonatocalix[7]arene ( $\boldsymbol{L 2 4}$, figure 27 a), which is a very flexible entity, was reported by Gaeta et al. with a polymer of formula $\left[\mathrm{Ba}_{3}(\boldsymbol{L 2 4})_{2}\left(\mathrm{C}_{12} \mathrm{H}_{12} \mathrm{~N}_{2}\right)_{5}\right]\left(\mathrm{H}_{2} \mathrm{O}\right)_{31}$. It is composed of a $2 \mathrm{D}$ arrays (figure $27 \mathrm{~b}$ ) made from $\mathrm{Ba}^{2+}$ cations connected with $p$-sulfonatocalix[7] arene (through the sulfonate bridges), adopting a distorted pinched double-cone conformation, encapsulating bipyridinium cations [63].

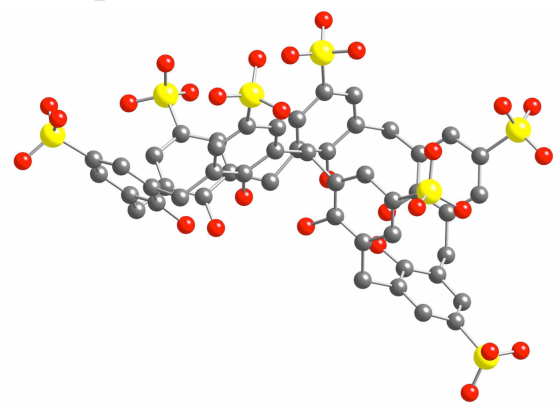

$L 24$

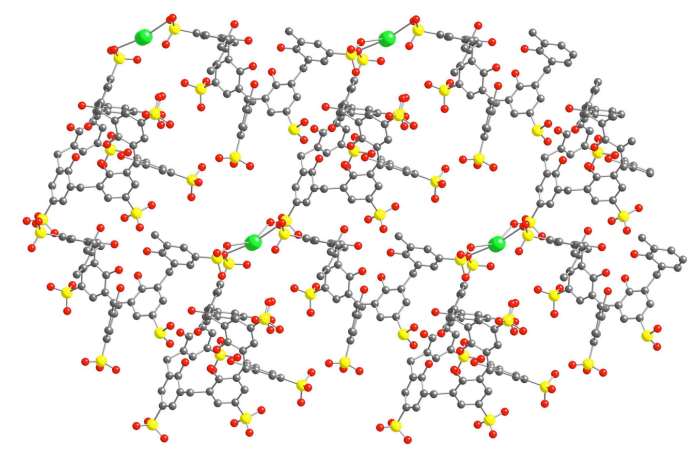

b

Figure 27: A portion of the X-ray structure showing $p$-sulfonatocalix[7]arene $\mathbf{L 2 4}$ in a pinched double-cone conformation (a) and the resulting 2D Coordination Polymer $\left[\mathrm{Ba}_{3}(\boldsymbol{L} 24)_{2}\left(\mathrm{C}_{12} \mathrm{H}_{12} \mathrm{~N}_{2}\right)_{5}\right]\left(\mathrm{H}_{2} \mathrm{O}\right)_{31}(\mathrm{~b})$. Green spheres represent $\mathrm{Ba}$ atoms. $\mathrm{H}$ atoms, solvent molecules and cations are not presented for sake of clarity. Adapted from Ref. [63]

\subsubsection{Octa-p-sulfonatocalix[8]arene}

A solid state extended structure involving odd $p$-sulfonatocalix[8]arene $(\boldsymbol{L 2 5}$, figure 
28 a) have also been reported. The conformation of the ligands is not predictable and is highly tuneable. When involved in Coordination Polymers, different conformation have been reported; the first was reported by Raston at al., who showed the assembly with Eu(III) together with 4,4'-bipyridine-N,N'-dioxide (bpy-N-ox), leading to a 3D Coordination Polymer of formula $\left\{\left[\mathrm{Eu}\left(\mathrm{H}_{2} \mathrm{O}\right)_{7}\right]_{033}\left[\mathrm{Eu}\left(\mathrm{H}_{2} \mathrm{O}\right)_{4}\right]_{2}\left[\mathrm{Eu}\left(\mathrm{H}_{2} \mathrm{O}\right)_{6}\right](\text { bpy-N-ox })_{45}(\boldsymbol{L 2 5})\right\}(\text { bpy-N-ox })_{15}\left(\mathrm{H}_{2} \mathrm{O}\right)_{8}$ (figure 28 b), where $\boldsymbol{L 2 5}$ presents a pleated loop conformation [64].

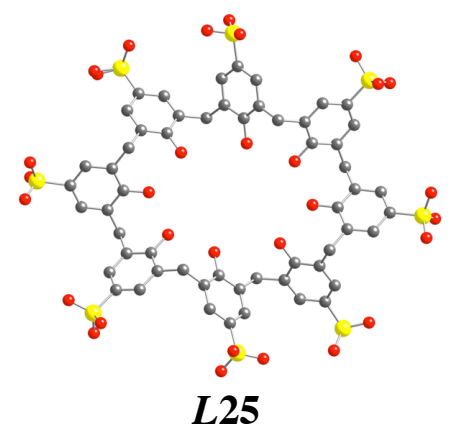

a

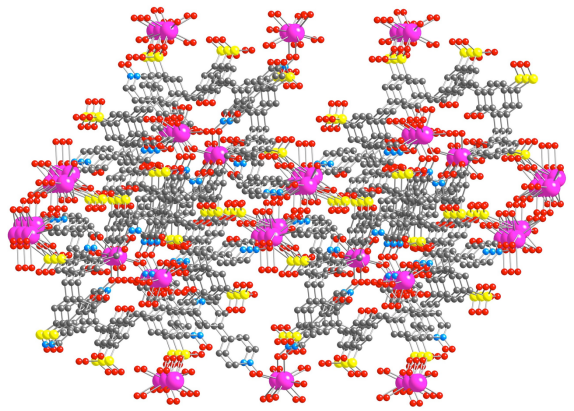

b

Figure 28: A portion of the X-ray structure showing $p$-sulfonatocalix[8]arene $\boldsymbol{L 2 5}$ in pleated loop conformation (a) and the resulting 3D Coordination Polymer $\left\{\left[\mathrm{Eu}\left(\mathrm{H}_{2} \mathrm{O}\right)_{]_{0 x}}\left[\mathrm{Eu}\left(\mathrm{H}_{2} \mathrm{O}\right)_{4}\right]_{[}\left[\mathrm{Eu}\left(\mathrm{H}_{2} \mathrm{O}\right)_{6}\right](\text { bpy-N-ox })_{s}(\boldsymbol{L} 25)\right\}\right.$ (bpy-Nox $)_{i s}\left(\mathrm{H}_{2} \mathrm{O}\right)_{s}(\mathrm{~b}) . \mathrm{H}$ atoms and solvent molecules are not presented for sake of clarity. Purplish-red spheres represent Eu atoms. Adapted from Ref. [64]

The decoration of calixarene platform with other coordinating hetero-elements was also performed, through the obtention of some phosphonato derivatives.

\subsection{7 p-phosphonatocalix[4]arene}

The upper rim of calix[4]arene has also been modified using the well-known phosphonato coordinating group.

Several Coordination Polymers have been reported, among them, the first one, based on a disubstituted species di-p-phosphonatocalix[4]arene (L26, figure 29 a) in cone conformation, was reported by Lukes et al., while the disubstituted compound was combined with $\mathrm{Ca}^{2+}$ and $\mathrm{Nd}^{3+}$ metallic salts leading to respectively $2 \mathrm{D}$ and $3 \mathrm{D}$ porous systems of formula $\left[\mathrm{Ca}(\boldsymbol{L 2 6})(\mathrm{MeOH})_{2}\right](\mathrm{MeOH})_{4}$ (figure 29 b) and $\left[\mathrm{Ln}(\boldsymbol{L 2 6})\left(\mathrm{NO}_{3}\right)\left(\mathrm{H}_{2} \mathrm{O}\right)_{4}\right]\left(\mathrm{Ln}=\mathrm{La}^{\mathrm{m}}, \mathrm{Pr}^{\mathrm{m}}\right.$ and $\left.\mathrm{Nd}^{\mathrm{m}}\right)$ (figure 29 c) respectively [65].

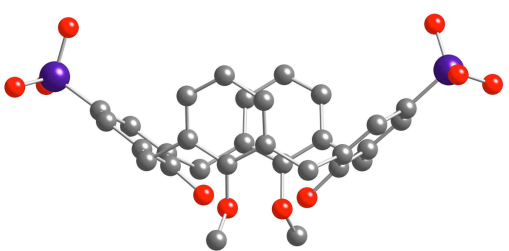

$L 26$

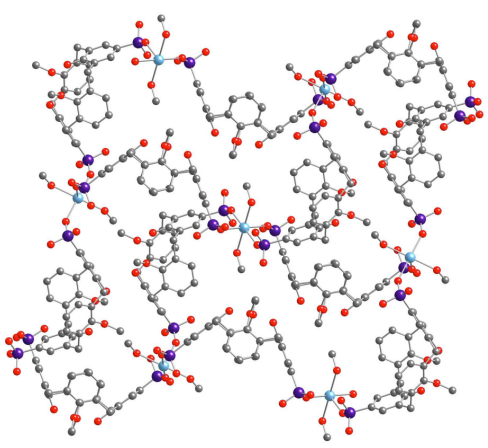

b

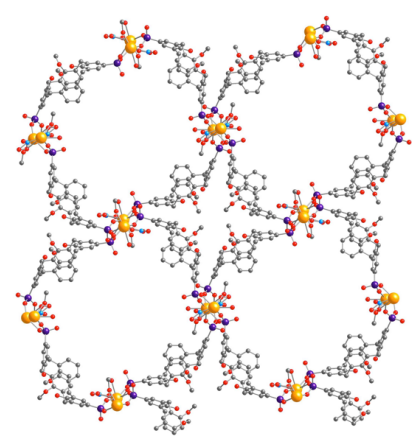

c

Figure 29: A portion of the X-ray structure showing the di-p-phosphonatocalix[4]arene $\mathbf{L 2 6}$ in cone conformation (a), the resulting 2D Coordination Polymer $\left[\mathrm{Ca}(\boldsymbol{L 2 6})(\mathrm{MeOH})_{2}\right](\mathrm{MeOH})_{4}(\mathrm{~b})$ and the $3 \mathrm{D}$ Coordination Polymer of formula $\left[\mathrm{Ln}(\boldsymbol{L 2 6})\left(\mathrm{NO}_{3}\right)\left(\mathrm{H}_{2} \mathrm{O}\right)_{4}\right]\left(\mathrm{Ln}=\mathrm{La}^{\mathrm{m}}, \mathrm{Pr}^{\mathrm{m}}\right.$ and $\left.\mathrm{Nd}^{\mathrm{m}}\right)(\mathrm{c})$. Violet, blue and goldish 
yellow spheres represent $\mathrm{P}, \mathrm{Ca}$, and $\mathrm{Ln}$ atoms, respectively. $\mathrm{H}$ atoms and solvent molecules are not presented for sake of clarity. Adapted from Ref. [65]

The tetrasubstituted corresponding species tetra-p-phosphonatocalix[4]arene in cone conformation ( $\boldsymbol{L 2 7}$, figure 30 a) has been reported by Raston et al. [66], leading to Coordination Polymers in the presence of $\mathrm{Ca}^{2+}$ metallic cations. The respective $1 \mathrm{D}$ and 2D Coordination Polymers present the following formula $\left[\mathrm{Ca}_{5}(\boldsymbol{L 2 7})_{2}\left(\mathrm{H}_{2} \mathrm{O}\right)_{22}\right]$ (figure $30 \mathrm{~b}$ ) and $\left[\mathrm{Ca}(\boldsymbol{L 2 7})\left(\mathrm{H}_{2} \mathrm{O}\right)_{3}\right] \mathrm{MeOH}$ (figure $30 \mathrm{c}$ ).

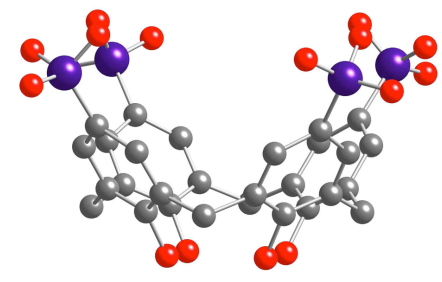

L27

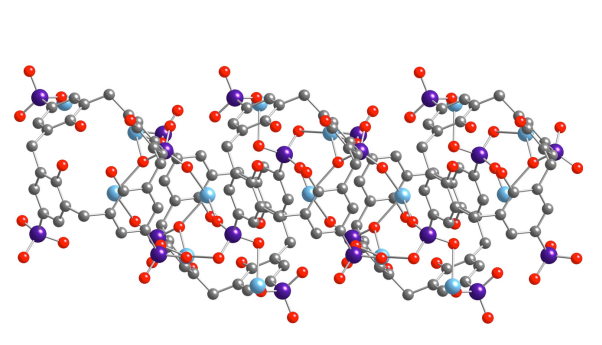

b

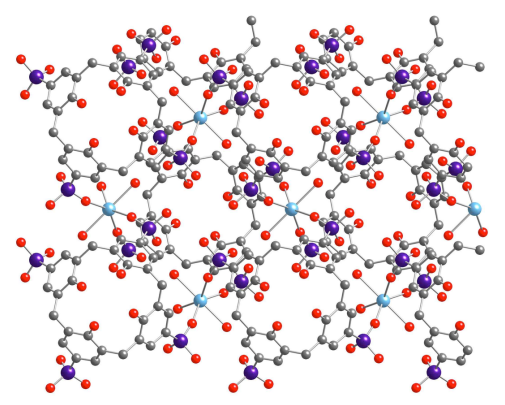

c

Figure 30: A portion of the X-ray structure showing the tetra- $p$-phosphonatocalix[4]arene $\boldsymbol{L 2 7}$ in cone conformation (a), the resulting 1D $\left[\mathrm{Ca}_{s}(\boldsymbol{L 2 7})_{2}\left(\mathrm{H}_{2} \mathrm{O}\right)_{2}\right]$ Coordination Polymer (b) and the 2D $\left[\mathrm{Ca}(\boldsymbol{L 2 7})\left(\mathrm{H}_{2} \mathrm{O}\right)_{3}\right]$ $\mathrm{MeOH}$ Coordination Polymer (c). Violet and blue spheres represent $\mathrm{P}$ and $\mathrm{Ca}$ atoms. $\mathrm{H}$ atoms and solvent molecules are not presented for sake of clarity. Adapted from Ref. [66]

\subsection{8 p-phosphineoxide-Calix[4]arene}

The upper rim of calix[4]arene has been also modified in order to obtain tetraphosphineoxide-tretrapropoxycalix[4] arene, ligand (L28, cone conformation, figure 31 a) that is coordinating through the $\mathrm{O}$ atoms. A $1 \mathrm{D}$ Coordination Polymer of formula $\left[\mathrm{Ni}_{2}(\boldsymbol{L 2 8})\left(\mathrm{NO}_{3}\right)_{4}\right]$ (figure 31 b) have been obtained by reaction with $\mathrm{Ni}\left(\mathrm{NO}_{3}\right)_{2}$, where the coordinating $\mathrm{NO}_{3}$ anions enter into the coordination sphere of the $\mathrm{Ni}^{2+}$ atoms [67].

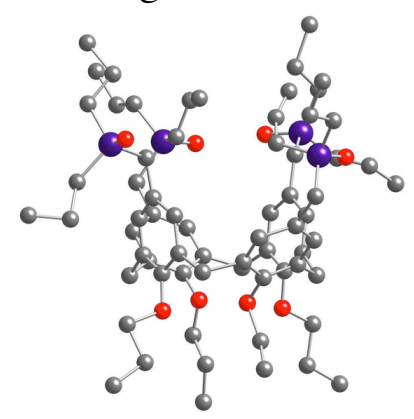

$L 28$

$\mathbf{a}$

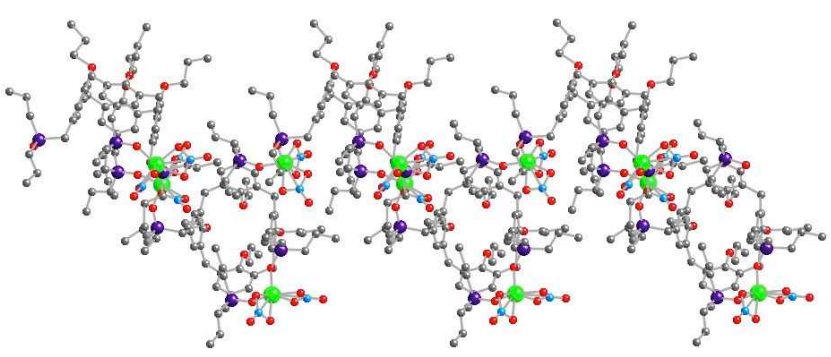

b

Figure 31: A portion of the X-ray structure showing the tetraphosphineoxide-tretrapropoxycalix[4]arene $\boldsymbol{L 2 8}$ in cone conformation (a) and the resulting 1D Coordination Polymer of formula $\left[\mathrm{Ni}_{2}(\boldsymbol{L 2 8})\left(\mathrm{NO}_{3}\right)_{4}\right]$ (b). Violet and green spheres represent $\mathrm{P}$ and $\mathrm{Ni}$ atoms. $\mathrm{H}$ atoms and solvent molecules are not presented for sake of clarity.

Adapted from Ref. [67] 
Thus, the functionalised upper rim calixarene platform has provided a large variety of Coordination Polymers with carboxylate and cyano coordinating groups, as well as sulfonate and phosphonato derivatives.

\subsection{Calix[4]arenes, thiacalix[4]arenes and tetramercaptothiacalix[4]rene with Lower Rim appended coordination sites}

\subsubsection{CA based Coordination Polymers}

Different type of chemical functionalizations have been performed on the calix[4]arenes platforms for enhancing of their abilities to bind metal cations. In this part the lower rim functionalization using coordination ether (or thia)crown together with diquinone has to be distinguished from the di or tetrasubstitution at the lower rim using an usual monodentate ligand.

\subsubsection{Calix[4](thiacrown)}

Calix-crowns, as the fusion of calix[4]arene and crown ether units, enable the divergent orientation of cavities sufficient to accommodate a variety of guests and to built new supramolecular Coordination Polymers.

The first example was provided by Lee et al., while assembling the symmetrical $p-\mathrm{H}$ calix[4]arene ligand with two different appended crowns, in 1,3-Alternate conformation calix[4](thiacrown) (L29, figure 32 a (Calix[4]bis(thiacrown-5) and $\mathbf{L 3 0}$ (calix[4]-bismonothiacrown), figure $32 \mathrm{~b}$ ), with $\mathrm{Cu}(\mathrm{I})$ halides, giving rise to two 3D compounds of formula $\left[\mathrm{Cu}_{2} \mathrm{I}_{2}(\boldsymbol{L 2 9})\right]$ (rhomboidic $\mathrm{Cu}-\mathrm{I}_{2}-\mathrm{Cu}$, figure $32 \mathrm{c}$ ) and $\left[\mathrm{Cu}_{4} \mathrm{I}_{4}(\boldsymbol{L 2 9})\right]$ (cubane-type $\mathrm{Cu}_{4} \mathrm{I}_{4}$, figure $32 \mathrm{~d}$ ), with strong $\mathrm{Cu}-\mathrm{Cu}$ interactions (2.607-2.995 $\AA$ ), leading to solid state luminescence $\left[\begin{array}{lllll}6 & 6\end{array}\right]$ Analogues $3 \mathrm{D}$ compounds of formula $\left[\left(\mathrm{Cu}_{3} \mathrm{I}_{3}\right)(\boldsymbol{L 2 9})\left(\mathrm{CH}_{3} \mathrm{CN}\right)\right]\left(\mathrm{CH}_{2} \mathrm{Cl}_{2}\right)\left(\mathrm{H}_{2} \mathrm{O}\right)_{2}$ (figure 32 e) or $\left[\left(\mathrm{Cu}_{2} \mathrm{I}_{2}\right)(\boldsymbol{L 2 9})_{2}\left(\mathrm{Cu}_{4} \mathrm{I}_{4}\right)\right]\left(\mathrm{CH}_{2} \mathrm{Cl}_{2}\right)\left(\mathrm{CH}_{3} \mathrm{CN}\right.$ ) (figure $32 \mathrm{f}$ ) presenting luminescent dependence on the solvatation are also reported [69], together with a $1 \mathrm{D}$ compound $\left[\left(\mathrm{Cu}_{4} \mathrm{~L}_{4}\right)(\mathbf{L 3 0})\left(\mathrm{CH}_{3} \mathrm{CN}\right)_{2}\right]$ (figure $32 \mathrm{~h}$ ) and also the inclusion of potassium cation in the crown ether cavity, leading to a compound of formula $\left[\mathrm{K}_{2}\left(\mathrm{Cu}_{4} \mathrm{I}_{6}\right)(\boldsymbol{L 3 0})\right]$ (figure $32 \mathrm{i}$ ) that presents "opening" of opposite aromatic rings in the host calixarene unit [70]. All the presented compounds present interesting luminescent properties. A $2 \mathrm{D}$ compound based on $\boldsymbol{L 3 0}$ and $\mathrm{Hg}(\mathrm{II})$, of formula $\left[\mathrm{K}_{2}(\boldsymbol{L 3 0}) \mathrm{Hg}_{4} \mathrm{I}_{10}\right]$ (figure $32 \mathrm{~g}$ ) was reported by the same group [71].

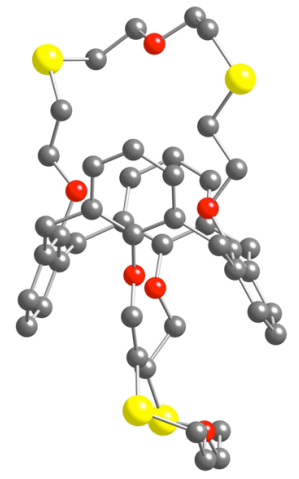

L29

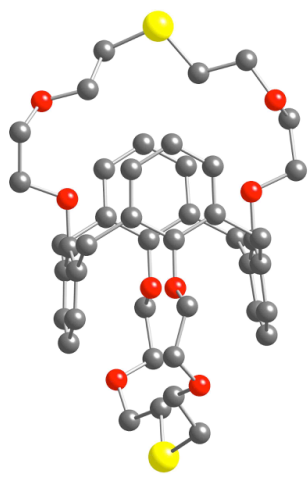

L30 
$\mathbf{a}$

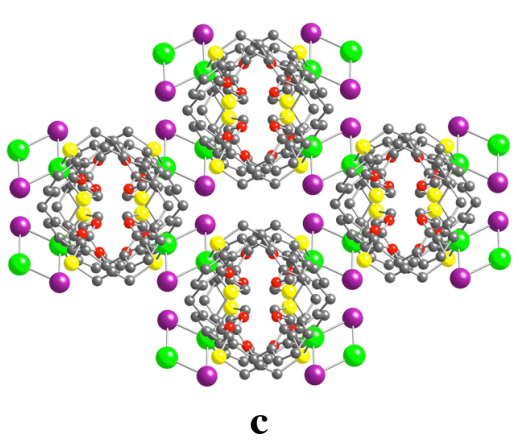

b

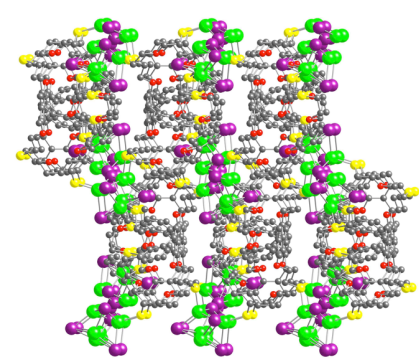

d

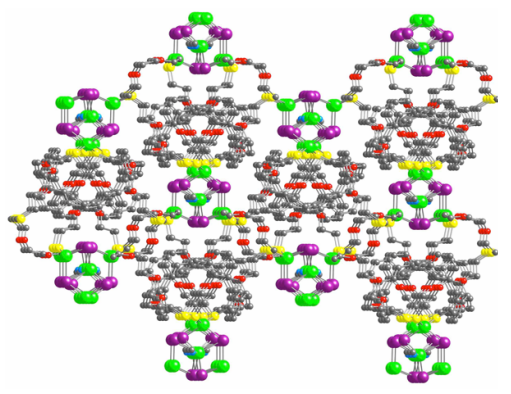

e
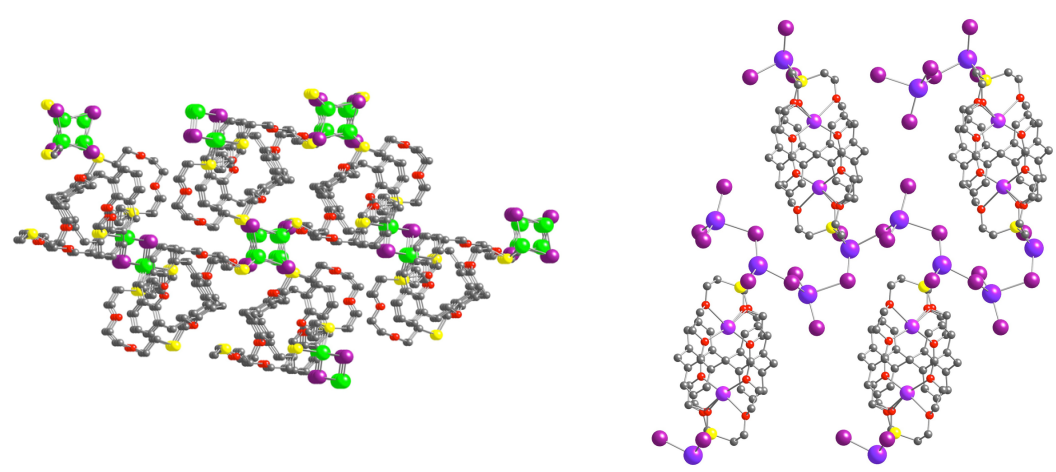

$\mathbf{f}$

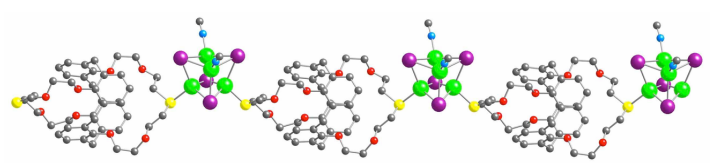

h

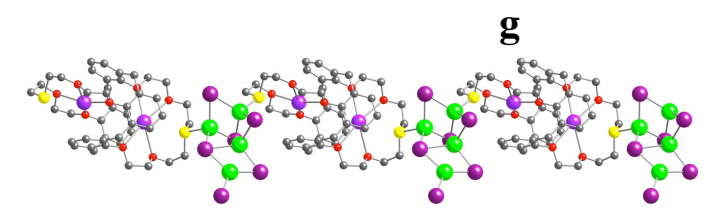

i

Figure 32: A portion of the X-ray structure showing the calix[4]bis(thiacrown-5) $\mathbf{L 2 9}$ (a) and calix[4]-bismonothiacrown $\boldsymbol{L 3 0}$ (b), the resulting 3D networks when $\boldsymbol{L 2 9}$ is combined with $\mathrm{CuI}_{\text {: }}\left[\mathrm{Cu}_{\mathrm{I}_{2}}(\boldsymbol{L 2 9})\right]$ (c),

$\left[\mathrm{Cu}_{4} \mathrm{~L}_{(}(\boldsymbol{L 2 9})\right](\mathrm{d})$, or $\left[\left(\mathrm{Cu}_{3} \mathrm{I}_{3}\right)(\boldsymbol{L 2 9})\left(\mathrm{CH}_{3} \mathrm{CN}\right)\right]\left(\mathrm{CH}_{2} \mathrm{Cl}_{2}\right)\left(\mathrm{H}_{2} \mathrm{O}\right)_{2}(\mathrm{e}),\left[\left(\mathrm{Cu}_{2} \mathrm{I}_{2}\right)(\boldsymbol{L 2 9})_{2}\left(\mathrm{Cu}_{1} \mathrm{I}_{1}\right)\right]\left(\mathrm{CH}_{2} \mathrm{Cl}_{2}\right)\left(\mathrm{CH}_{3} \mathrm{CN}\right)(\mathrm{f})$ or when $\boldsymbol{L 3 0}$ is combined $\mathrm{Hg}(\mathrm{II}),\left[\mathrm{K}_{2}(\boldsymbol{L 3 0}) \mathrm{Hg}_{i} \mathrm{I}_{i}\right](\mathrm{g})$, the $1 \mathrm{D}$ compounds $\left[\left(\mathrm{Cu}_{i} \mathrm{~L}_{i}\right)(\boldsymbol{L 3 0})\left(\mathrm{CH}_{2} \mathrm{CN}\right)_{2}\right](\mathrm{h})$ and $\left[\mathrm{K}_{2}\left(\mathrm{Cu}_{i} \mathrm{I}_{2}\right)(\boldsymbol{L 3 0})\right](\mathrm{i})$.

Green and violet spheres represent $\mathrm{Cu}$ and $\mathrm{Hg}$ atoms, respectively. $\mathrm{H}$ atoms and solvent molecules are not presented for sake of clarity. Adapted from Ref. [68-71]

The same authors also developed the coordination chemistry of unsymmetrical calix[4]crowns, with the formation of two new ligands $\mathbf{L 3 1}$ and $\mathbf{L 3 2}$ (monothiacrown-5calix[4]arene, figures $33 \mathrm{a}$ and $\mathrm{b}$ respectively). Their reaction with $\mathrm{KI}$ and $\mathrm{CuI}$ lead to two $\mathrm{DD}$ polymers of formula $\left[\mathrm{K}_{2}(\boldsymbol{L 3 1})\left(\mathrm{Cu}_{7} \mathrm{I}_{9}\right)\right]$ (figure $33 \mathrm{c}$ ) and $\left.\left[\mathrm{K}(\boldsymbol{L 3 2}) \mu_{2}-\mathrm{Cu}_{3} \mathrm{I}_{4}\right)\right]$ (figure $33 \mathrm{~d}$ ), while the reaction with $\mathrm{KPF}_{6}, \mathrm{CuI}$ and $\mathrm{HgI}_{2}$ leads to a $1 \mathrm{D}$ bimetallic Coordination Polymer of formula $\left[\mathrm{K}(\mathbf{L 3 2})\left(\mathrm{CuHgI}_{4}\right)\right]$ (figure $33 \mathrm{e}$ ) [72].
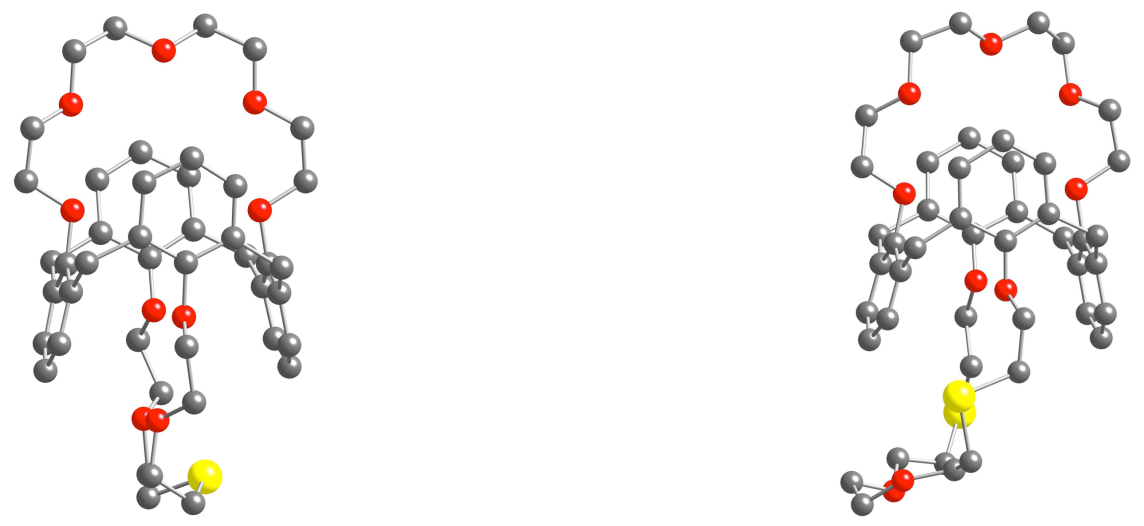


\section{L31}

a

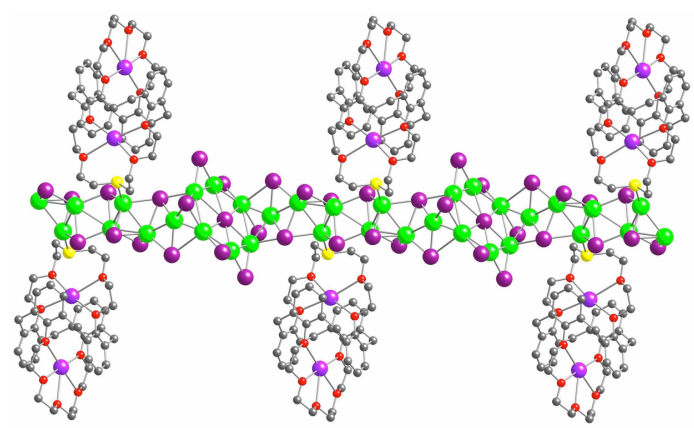

c
L32

b

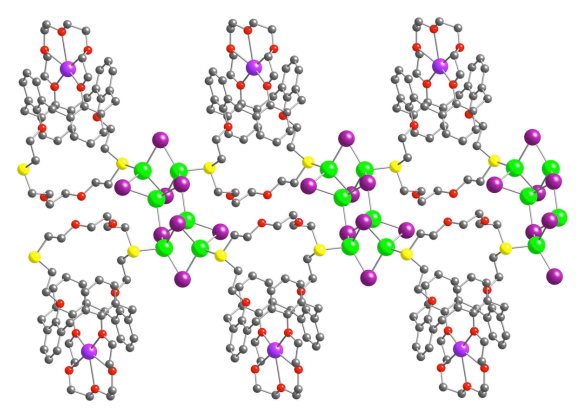

d

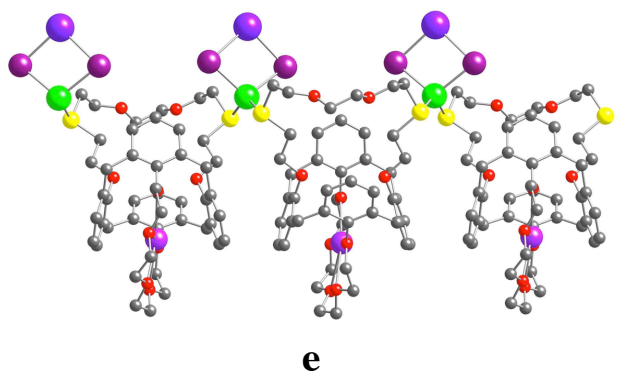

Figure 33: A portion of the X-ray structure showing the unsymmetrical bisthiacrown-5-calix[4]arene $\mathbf{L 3 1}$ (a), bisthiacrown-5-calix[4]arene $\boldsymbol{L 3 2}$ (b), the resulting 1D network when combined with $\mathrm{CuI}_{[}\left[\mathrm{K}_{2}(\boldsymbol{L 3 1})\left(\mathrm{Cu}_{7} \mathrm{I}_{9}\right)\right](\mathrm{c})$, the 1D network $\left.\left[\mathrm{K}(\boldsymbol{L 3 2}) \mu_{2}-\mathrm{Cu}_{\mathbf{I}_{4}}\right)\right](\mathrm{d})$ and the bimetallic 1D network $\left[\mathrm{K}(\boldsymbol{L 3 2})\left(\mathrm{CuHgI}_{4}\right)\right](\mathrm{e})$. Violet, purplish-red and green spheres represent $\mathrm{Hg}, \mathrm{K}$ and $\mathrm{Cu}$ atoms, respectively. $\mathrm{H}$ atoms and solvent molecules are not presented for sake of clarity. Adapted from Ref. [72]

\subsubsection{Disubstituted Calix[4]diquinone}

Examples arising from the family of disubstituted calix[4]diquinone are provided by Beer et al., with an amide and an acid disubstituted p-tert-butylcalix[4]diquinone ( $\boldsymbol{L 3 3}$ and $\boldsymbol{L 3 4}$, figure 34 a and c, respectively) derivatives, where the involvement of upper rim oxygen atoms, together with the substituted lower rim, combined in solution with $\mathrm{Na}$ (I) [73] or $\mathrm{Pb}$ (II) [74] leads to 1D systems and 3D porous systems respectively, with the respective formulas : $\left[\mathrm{Na}(\boldsymbol{L 3 3})_{2} \mathrm{ClO}_{4}\right]$ (figure $34 \mathrm{~b}$ and c) and the resulting $3 \mathrm{D}\left[\mathrm{Pb}_{9}(\boldsymbol{L 3 4})_{3}\left(\mathrm{ClO}_{4}\right)_{6}(\mathrm{OH})_{6}\right]\left(\mathrm{H}_{2} \mathrm{O}\right)_{16}$ (figure $34 \mathrm{~d})$. In both cases, the disubstituted calix[4]diquinone adopts the usual distorted cone conformation with aromatic rings pseudo-perpendicular and quinone rings pseudo-parallel to the plane of the four methylene atoms.

In both systems, the network is formed by the simultaneous coordination of the oxygen atoms of both the upper and lower rim, leading to a 1D sodium based Coordination Polymer (figure $33 \mathrm{~b}$ ) and a $3 \mathrm{D}$ porous $\mathrm{Pb}(\mathrm{II})$ based polymer (figure $34 \mathrm{~d}$ ) containing channels of $c a .14 \AA$ in diameter. 


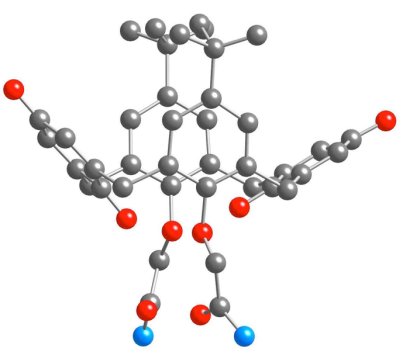

L33

a

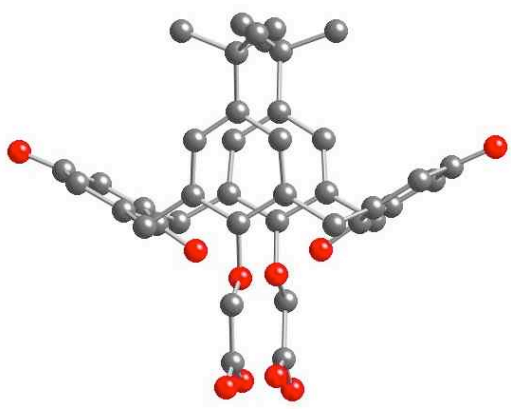

L34

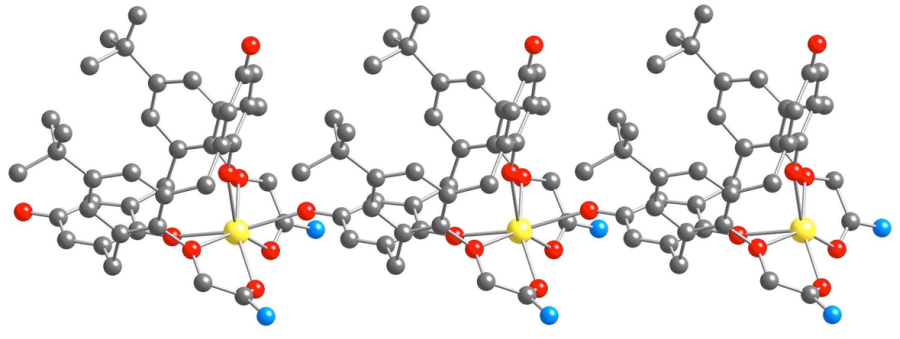

b

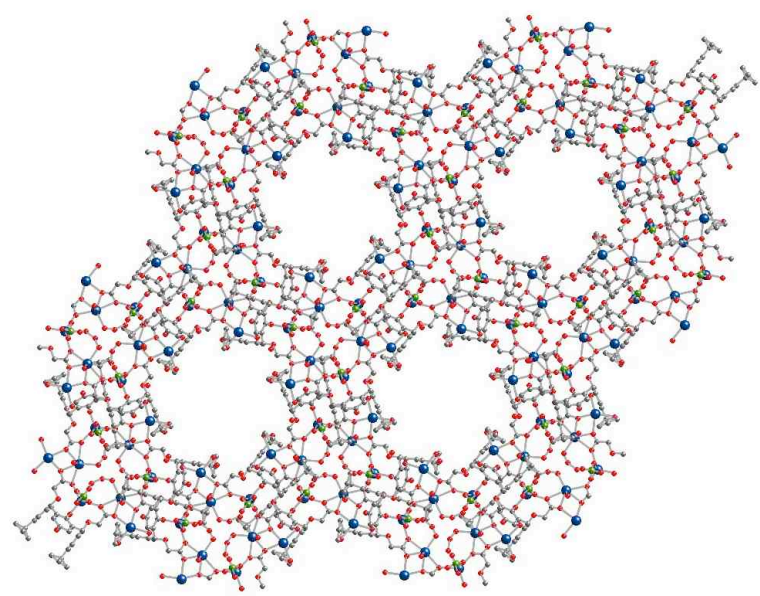

d

Figure 34: A portion of the X-ray structure showing the amide (L33) and the acid (L34) disubstituted $p$-tertbutylcalix[4]diquinone in cone conformation(a) and (c), together with their corresponding 1D Coordination Polymer obtained with $\mathrm{NaClO}_{4}\left[\mathrm{Na}(\boldsymbol{L 3 3})_{2} \mathrm{ClO}_{4}\right](\mathrm{b})$, and the $3 \mathrm{D}$ porous network

$\mathrm{Pb}\left(\mathrm{ClO}_{4}\right)_{2}\left[\mathrm{~Pb}_{9}(\boldsymbol{L 3 4})_{3}\left(\mathrm{ClO}_{4}\right)_{6}(\mathrm{OH})_{6}\right]\left(\mathrm{H}_{2} \mathrm{O}\right)_{16}(\mathrm{~d})$. Yellow and dark-blue spheres represent $\mathrm{Na}$ and $\mathrm{Pb}$ atoms, respectively. $\mathrm{H}$ atoms and solvent molecules are not presented for sake of clarity. Adapted from Ref. [73-74]

\subsubsection{Disubstituted calix[4]arene}

\subsection{Pyridine functionalization}

One of the first example of Coordination Polymers based on pyridyl derivatives of CA was given by Castillo et al. [75], where two $\gamma$-pyridyl coordinating groups have been appended to a calixarene in cone conformation, leading to a bis-monodentate ligand, bispicolyl-p-tert-butylcalix[4]arene (L35, figure 35 a), that, when combined with Copper(II) acetate lead to in a 1D system, displaying the formation of paddle-wheel dimeric unit connected of formula $\left[\mathrm{Cu}_{2}(\mu-\mathrm{OAc})_{4}(\mu-\mathbf{L 3 5})\right] \mathrm{S}$, where $\mathrm{S}$ are solvent molecules (figure $35 \mathrm{~b}$ ). In the compound, the copper(II) atoms display the well known paddle wheel feature, and the exchange coupling between the paramagnetic centres have been estimated from ESR measurements. The same ligand, when combined with $\mathrm{CuCl}_{2}$, afforded an analogous coordination pattern, leading to a $1 \mathrm{D}$ compound of formula $\left[\mathrm{Cu}(\boldsymbol{L 3 5}) \mathrm{Cl}_{2}\right]$ (figure $35 \mathrm{c}$ ) [76]. 


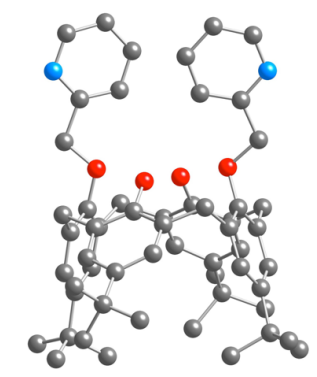

\section{L35}

a

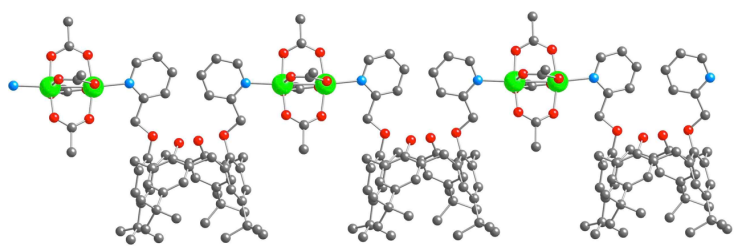

b

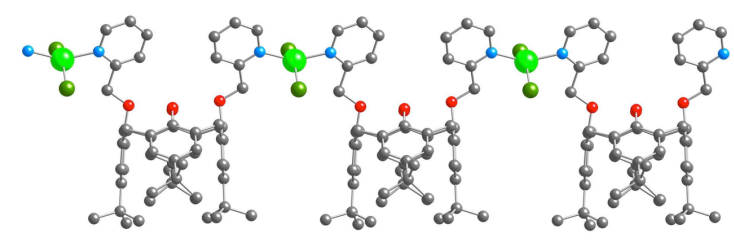

c

Figure 35: A portion of the X-ray structure showing bispicolyl-p-tert-butylcalix[4]arene $\mathbf{L 3 5}$ in cone conformation (a), the resulting $1 \mathrm{D}$ networks when combined with $\mathrm{Cu}(\mathrm{OAc})_{2}:\left[\mathrm{Cu}_{2}(\mu-\mathrm{OAc})_{4}(\mu-\boldsymbol{L 3 5})\right] \mathrm{S}(\mathrm{b})$ and $\left[\mathrm{Cu}(\boldsymbol{L 3 5}) \mathrm{Cl}_{2}\right]$, obtained when combined with $\mathrm{CuCl}_{2}$ (c). Green spheres represent $\mathrm{Cu}$ atoms. $\mathrm{H}$ atoms and solvent molecules are not presented for sake of clarity. Adapted from Ref. [75-76]

When the tetrasubstituted calix[4]arene derivative with four appended meta pyridyl moieties adopted in cone conformation (L36, figure 36 a) was combined with silver cations, the $2 \mathrm{D}$ Coordination Polymer formation of formula $\left[\mathrm{Ag}_{4}(\boldsymbol{L 3 6})\left(\mathrm{NO}_{3}\right)_{4}\right]$ have been observed (figure $36 \mathrm{~b}$ ) [77]. It was shown that the obtained compound displays photocatalytic activity for degradation of nitrobenzene in aqueous solutions under UV-light.

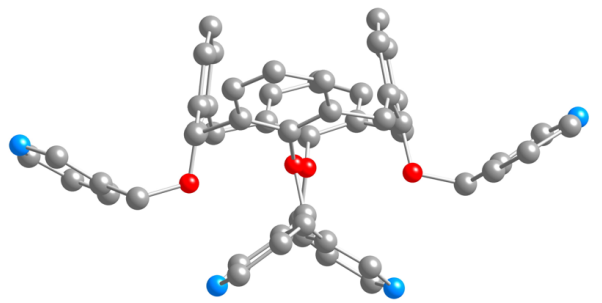

L36

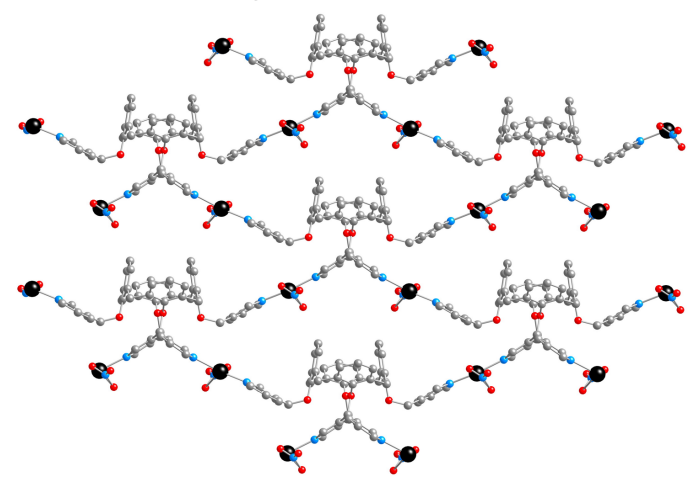

b

Figure 36: A portion of the X-ray structure showing tetrapyridyl calix[4]arene $\boldsymbol{L 3 6}$ in cone conformation (a) and the resulting 2D networks when combined with $\mathrm{AgNO}_{3}:\left[\mathrm{Ag}(\boldsymbol{L 3 6})\left(\mathrm{NO}_{3}\right)\right](\mathrm{b})$. Black spheres represent $\mathrm{Ag}$ atoms.

$\mathrm{H}$ atoms, solvent molecules and anions are not presented for sake of clarity. Adapted from Ref. [77]

\subsection{Carboxylate functionalization}

The first example was provided by Che et al., where a disubtitued calixarene bis(hydroxycarbonylmethoxy)-26-dimethoxy-p-tert-butylcalix[4]arene in 1,3-Alternate conformation (L37, figure 37 a) with carboxylate coordinating groups, was combined with 
$\mathrm{Co}(\mathrm{II})$ salt to lead to a cationic $3 \mathrm{D}$ compound (10,3 network) of formula $\left[\mathrm{K}_{3} \mathrm{Co}_{2}(\mathbf{L 3 7})_{3}(\mathrm{EtOH})_{6}\right] \mathrm{Cl}$ (figure $37 \mathrm{~b}$ ) [78]. This compound presents some NLO properties.

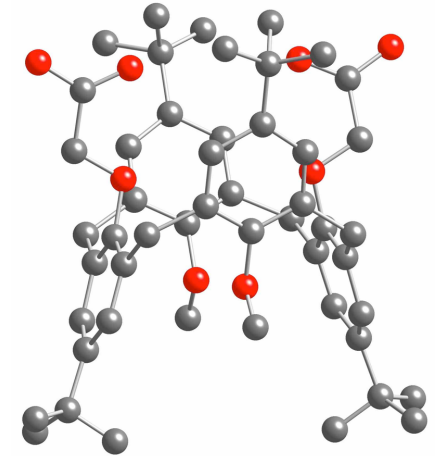

L37

a

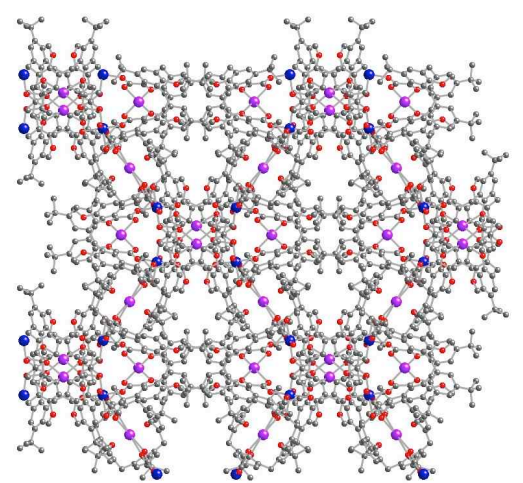

b

Figure 37: A portion of the X-ray structure showing the bis(hydroxycarbonylmethoxy)-26-dimethoxy-p-tertbutylcalix[4]arene $\boldsymbol{L 3 7}$ in 1,3-Alternate conformation (a) and the resulting 3D network obtained through combination with $\mathrm{CoCl}_{2} \cdot 6 \mathrm{H}_{2} \mathrm{O}:\left[\mathrm{K}_{3} \mathrm{Co}_{2}(\boldsymbol{L 3 7})_{(},(\mathrm{EtOH})_{6}\right] \mathrm{Cl}(\mathrm{b})$. Blue and purplish-red spheres represent $\mathrm{Co}$ and $\mathrm{K}$ atoms, respectively. $\mathrm{H}$ atoms and solvent molecules are not presented for sake of clarity. Adapted from Ref. [78]

The second example of disubstituted coordinating calix[4]arene was provided by Humphrey et al., starting from the $p$-H-calix[4]arene (bis(methoxycarboxylic acid)dihydroxycalix[4]arene (L38, figure 38 a) parent compound, in cone conformation. When combined with $\mathrm{Zn}^{2+}$ cations, it leads to an infinite chain of formula $\left[\mathrm{Zn}(\boldsymbol{L 3 8})_{2}(\mathrm{DMF})\left(\mathrm{H}_{2} \mathrm{O}\right)\right]$ (figure 38 b) [79]. Preliminarily sorption analysis of these compounds revealed a very low uptake of gas for these compounds.

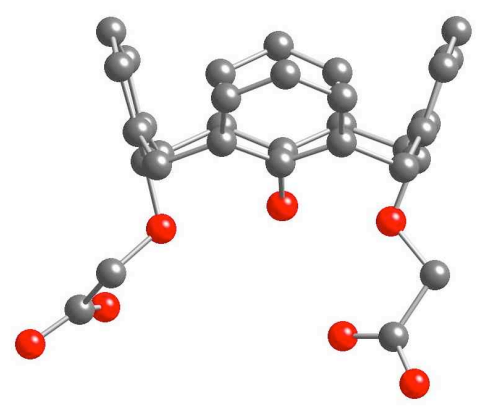

L38

a

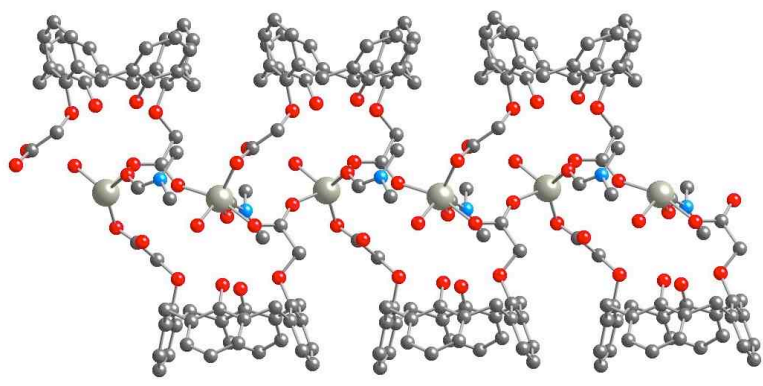

b

Figure 38: A portion of the X-ray structure showing the bis(methoxycarboxylic acid)-dihydroxycalix[4]arene $\boldsymbol{L 3 8}$ in cone conformation (a) and the resulting 1D network of formula $\left[\mathrm{Zn}(\boldsymbol{L 3 8})_{2}(\mathrm{DMF})\left(\mathrm{H}_{2} \mathrm{O}\right)\right]$ when combined with $\mathrm{Zn}(\mathrm{OAc})_{2}$ (b). Light-grey spheres represent $\mathrm{Zn}$ atoms. $\mathrm{H}$ atoms and solvent molecules are not presented for sake of clarity. Adapted from Ref. [79]

All these examples evidenced that the conformation of the rigid calix[4]arene together with the nature of the other non coordinating groups present at the lower rim of the macrocyclic platform is crucial for the control of the final dimensionality of the formed networks.

Using tetrasubstituted species may lead to more symmetrical Coordination Polymers. 


\subsubsection{Tetrasubstituted calix[4]arene}

\subsection{Carboxylate functionalization}

As already mentioned, few tetrasubstituted calixarene are involved in Coordination Polymers.

One example was given by Lee at al., that presented two tetrasubstituted carboxylate based ligands in 1,3-Alternate conformation (tetraacetate $p$-H-calix[4]arene $\mathbf{L 3 9}$, figure 39 a tetrabenzeoate $p$-H-calix[4]arene $\mathbf{L 4 0}$, figure 39 b). Both were combined with silver salts and lead to the well-known non tubular 1D coordination pattern, with the differences that some argentophilic interaction increased the number of silver atoms, and that the formula of the Coordination Polymers are $\left[\left(\mu_{2}-\mathrm{Ag}\right)_{2}(\mathrm{Ag})_{2}(\boldsymbol{L 3 9})\right]\left(\mathrm{H}_{2} \mathrm{O}\right)_{4} \quad$ (figure $\left.39 \quad \mathrm{c}\right)$ and $\left[\left(\mu_{2}-\right.\right.$ $\left.\mathrm{Ag})_{4}(\boldsymbol{L 4 0})\left(\mathrm{H}_{2} \mathrm{O}\right)\left(\mathrm{CH}_{3} \mathrm{OH}\right)_{3}\right]\left(\mathrm{H}_{2} \mathrm{O}\right)_{2}$ (figure 39 d) [80]. In both cases the stoichiometry $\mathrm{M} / \mathrm{L}$ is equal to $4 / 1$.

The combination of ligand $\mathbf{L 3 9}$ with $\mathrm{Pb}\left(\mathrm{NO}_{3}\right)_{2}$ leads to the formation of a 3D Coordination Polymer of formula $\left[\mathrm{Pb}_{2}(\boldsymbol{L 3 3})\right] \cdot 2 \mathrm{DMF}$ presenting a ths topology (figure $39 \mathrm{e}$ ) [81]. Interestingly, the 3D system exhibits reversible solvation and desolvation process, together with interesting $\mathrm{CO}_{2}$ adsorption behaviour and luminescent properties.

The use of $\boldsymbol{L 3 9}$ led to formation of 3D Coordination Polymers when combined with Cd (II) cations. In the compound of formula $\left[\mathrm{Cd}_{4}(\boldsymbol{L 3 9})_{2}(\mathrm{DMF})_{6}\right]$ (figure $39 \mathrm{f}$ ), the calixarene based molecular building blocks are connected by tetranuclear Cd (II) cluster core. The obtained compound displays intense blue emission, implying that this tetranuclear $\mathrm{Cd}$ (II) Coordination Polymer could be a suitable material in the area of luminescence research [82].

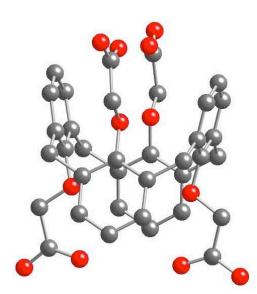

L39

a

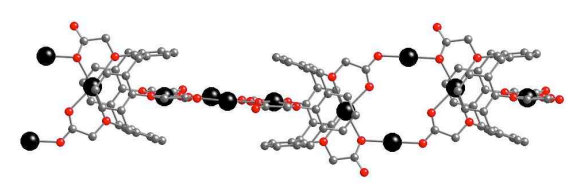

c

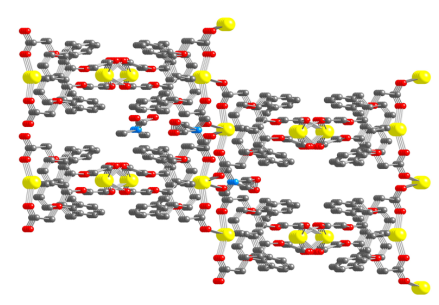

e

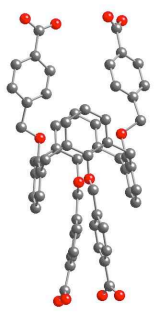

$L 40$

b

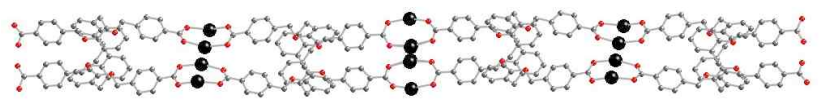

d

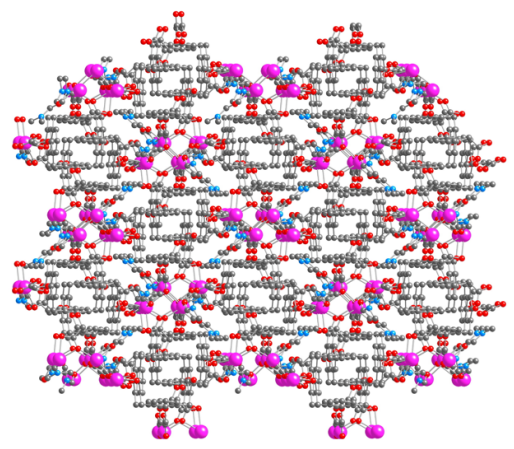

f

Figure 39: A portion of the X-ray structure showing the tetraacetate calix[4]arene $\boldsymbol{L 3 9}$ (a) and the tetrabenzoate $p$-H-calix[4]arene $\boldsymbol{L} \mathbf{4 0}$ (b) in 1,3-Alternate conformation, and the resulting 1D corresponding networks when 
combined with $\mathrm{Ag}:\left[\left(\mu_{2}-\mathrm{Ag}\right)_{2}(\mathrm{Ag})_{2}(\mathrm{L3} 8)\right]\left(\mathrm{H}_{2} \mathrm{O}\right)_{4}(\mathrm{c})$, the tubular $\left[\left(\mu_{2}-\mathrm{Ag}\right)_{{ }_{(}}(\boldsymbol{L 4 0})\left(\mathrm{H}_{2} \mathrm{O}\right)\left(\mathrm{CH}_{3} \mathrm{OH}\right)_{3}\right]\left(\mathrm{H}_{2} \mathrm{O}\right)_{2}(\mathrm{~d}), 3 \mathrm{D}$ $\left[\mathrm{Pb}_{2}(\boldsymbol{L 3 9})\right](\mathrm{DMF})_{2}(\mathrm{e})$ and $3 \mathrm{D}\left[\mathrm{Cd}(\boldsymbol{L 3 9})_{2}(\mathrm{DMF})_{6}\right]$ (f). Black, yellow and purplish-red spheres represent $\mathrm{Ag}, \mathrm{Pb}$ and $\mathrm{Cd}$ atoms, respectively. $\mathrm{H}$ atoms and solvent molecules are not presented for sake of clarity. Adapted from Ref. [80-82]

Other examples arising from tetraacetate $p$-H-calix[4]arene ( $\mathbf{L 4 1}$ figure 40 a) and tetraacetate p-tert-butylcalix[4]arene ( $\mathbf{L 4 2}$ figure 40 b) derivatives, blocked in cone conformation were provided by Yang et al., with bimetallic Coordination Polymers when these tetrasubstituted ligands are combined with transition metals together with alkali cation [83]. Using also an ancillary $\mathrm{N}$ donor several Coordination Polymers were obtained, for example ligand 1,4bis(1H-imidazol-1-yl)butane (imi-4) or 1,4-bis(1,2,4-triazole-1-yl)butane (tria-4), two isomorphous 2D compounds of formula $\left[\mathrm{Zn}_{6} \mathrm{Na}_{6}(\boldsymbol{L 4 1})_{4}(\mathrm{OH})_{2}(\mathrm{imi}-4)\left(\mathrm{H}_{2} \mathrm{O}\right)_{4}\right]\left(\mathrm{H}_{2} \mathrm{O}\right)_{5}$ (figure $40 \mathrm{c}$ ) and $\left[\mathrm{Zn}_{6} \mathrm{Na}_{6}(\boldsymbol{L 4 1})_{4}(\mathrm{OH})_{2}\left(\right.\right.$ tria-4) $\left.\left(\mathrm{H}_{2} \mathrm{O}\right)_{4}\right]\left(\mathrm{H}_{2} \mathrm{O}\right)_{5}$ (figure 40 d) were obtained. $\left[\mathrm{Zn}_{6} \mathrm{Na}_{6}(\boldsymbol{L 4 1})_{4}(\mathrm{OH})_{2}(\mathrm{imi}-4)\left(\mathrm{H}_{2} \mathrm{O}\right)_{4}\right]\left(\mathrm{H}_{2} \mathrm{O}\right)_{5}$ present luminescent properties in the solid state.

Using the same ligand, two other simple 1D Coordination Polymers of formula $\left[\mathrm{Co}_{4} \mathrm{Na}_{2}(\boldsymbol{L 4 1})_{2}(\mathrm{OH})_{2}\left(\mathrm{H}_{2} \mathrm{O}\right)_{6}\right]\left(\mathrm{H}_{2} \mathrm{O}\right)_{7}$ (figure 40 e) and $\left[\mathrm{Cu}_{3} \mathrm{Na}_{2}(\boldsymbol{L 4 0})_{2}\right]$ (figure $40 \mathrm{f}$ ) were obtained. Using the more bulky ligand $\mathbf{L 4 2}$, two 1D ribbon like Coordination Polymers of formula $\left[\mathrm{Cu}_{7} \mathrm{Na}_{4}(\boldsymbol{L 4 2})_{4}(\mathrm{OH})_{2}\left(\mathrm{H}_{2} \mathrm{O}\right)_{5}\right]\left(\mathrm{H}_{2} \mathrm{O}\right)_{6}$ (figure $40 \mathrm{~g}$ ) and $\left[\mathrm{Zn}_{2} \mathrm{Na}(\boldsymbol{L 4 2})(\mathrm{OH})\left(\mathrm{H}_{2} \mathrm{O}\right)\right]\left(\mathrm{H}_{2} \mathrm{O}\right)_{2}$ (figure $40 \mathrm{~h}$ ) were also obtained. Using a nickel(II) hexaazamacrocyclic complex (Ni-hexaza), a ladder like 1D Coordination Polymer of formula $\left[(\mathrm{Ni} \text {-hexaza) })_{3}(\boldsymbol{L 4 2})_{2}\right](\mathrm{DMF})_{3} \mathrm{H}_{2} \mathrm{O}$ (figure 40 i) was reported [84].

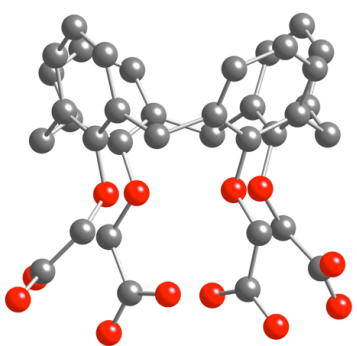

$L 41$

a

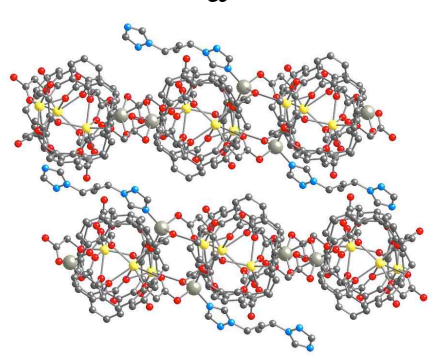

d

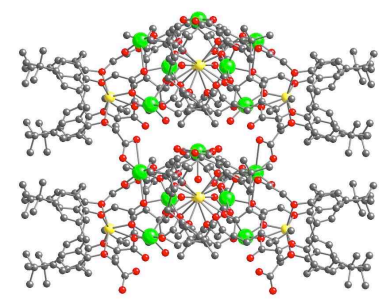

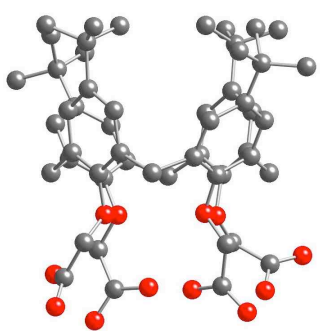

$L 42$

b

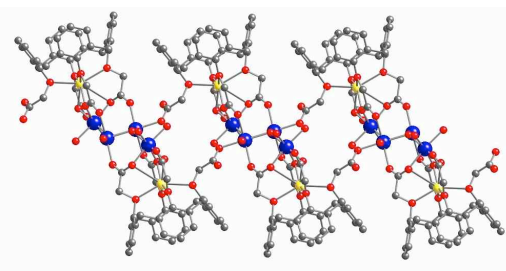

e

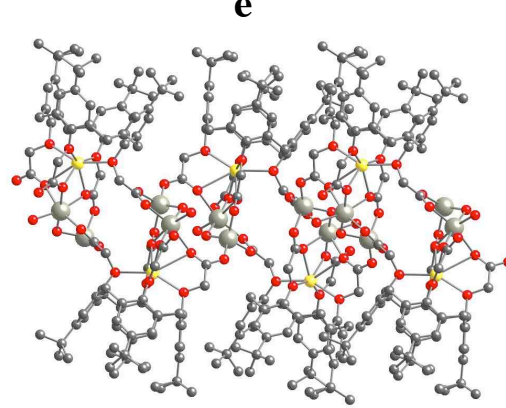

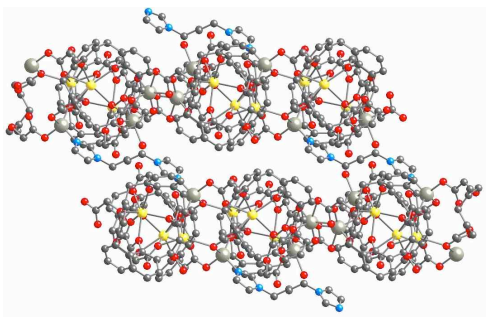

c

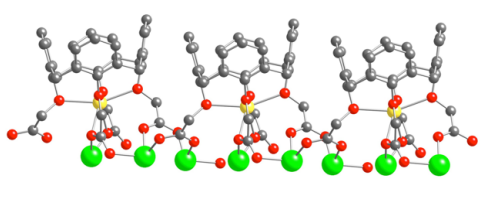

f

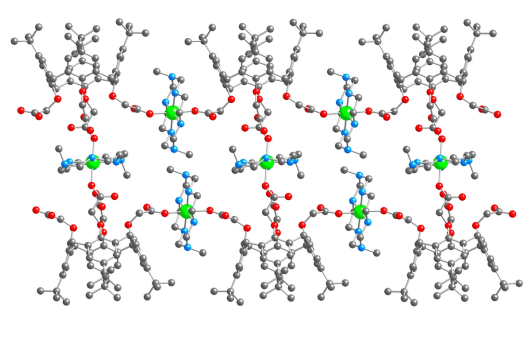


Figure 40: A portion of the X-ray structure showing the tetrabenzoate of $p$-H-calix[4]arene $\boldsymbol{L 4 1}$ (a) and the tetraacetate of $p$-tert-butylcalix [4] arene $\boldsymbol{L 4 2}$ (b) in cone conformation and the resulting 2D isomorphous

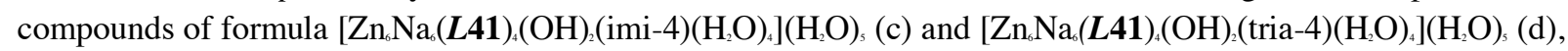
together with the 1D compounds of formula $\left[\mathrm{Co}_{4} \mathrm{Na}_{2}(\boldsymbol{L 4 1})_{2}(\mathrm{OH})_{2}\left(\mathrm{H}_{2} \mathrm{O}\right)_{6}\right]\left(\mathrm{H}_{2} \mathrm{O}\right)_{7}(\mathrm{e})$, the 1D compound

$\left[\mathrm{Cu}_{3} \mathrm{Na}_{2}(\boldsymbol{L 4 1})_{2}\right]$ (f) and also the 1D ribbon-like Coordination Polymers $\left[\mathrm{Cu}_{1} \mathrm{Na}_{4}(\boldsymbol{L 4 2})_{4}(\mathrm{OH})_{2}\left(\mathrm{H}_{2} \mathrm{O}\right)_{3}\right]\left(\mathrm{H}_{2} \mathrm{O}\right)_{6}(\mathrm{~g})$, $\left[\mathrm{Zn} n_{2} \mathrm{Na}(\boldsymbol{L 4 2})(\mathrm{OH})\left(\mathrm{H}_{2} \mathrm{O}\right)\right]\left(\mathrm{H}_{2} \mathrm{O}\right)_{2}(\mathrm{~h})$ and the 1D Coordination Polymer [(Ni-hexaza) $\left.)_{(}(\boldsymbol{L 4 2})_{2}\right](\mathrm{DMF})_{,} \mathrm{H}_{2} \mathrm{O}$ (i). Darkblue, yellow, green and light-grey spheres represent $\mathrm{Co}, \mathrm{Na}, \mathrm{Cu}$ (or $\mathrm{Ni}$ ), and $\mathrm{Zn}$ atoms, respectively. $\mathrm{H}$ atoms and solvent molecules are not presented for sake of clarity. Adapted from Ref. [83-84]

Through these examples we may conclude that the nature of the formed Coordination Polymers is totally dependant on the conformation of the used functionalised calixarene as well as form the different combinations of used metals.

\subsubsection{TCA based Coordination Polymers}

Different functionalization have been performed on the lower rim of thiaxalix[4]arene and all the reported ligands are tetrasubstituted, contrary to the previous case, no disubstituted TCA have been reported. The approach, initiated by Hosseini et al., to graft coordinating groups on TCA in 1,3-Alternate conformation, leading to tetrasubstituted TCA, was then intensively developed.

\subsubsection{Cyano functionalization}

Series of tetradentate ligands in 1,3-Alternate conformation were obtained. The first series was a weak coordinating cyano derivative, with propyl spacer between the phenoxy and the cyano (tetracyano $p$-tert-butyl-thiacalix[4]arene ligand ( $\mathbf{L 4 3}$, figure 41 a), leading, independently on the nature of the used silver anion $\left(\mathrm{X}=\mathrm{BF}_{4}, \mathrm{PF}_{6}\right.$ or $\left.\mathrm{SbF}_{6}\right)$ to a non tubular 1D system with a $1 / 1$ ratio of formula ; with a tetrahedral environment of the $\mathrm{Ag}^{+}$cation and a formula of $[\operatorname{Ag}(\boldsymbol{L 4 3}) \mathrm{X}] . S$, (S=solvent molecules) (figure $41 \mathrm{~b}$ ) [85].

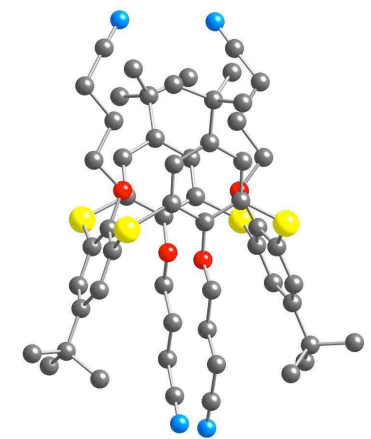

$L 43$

a

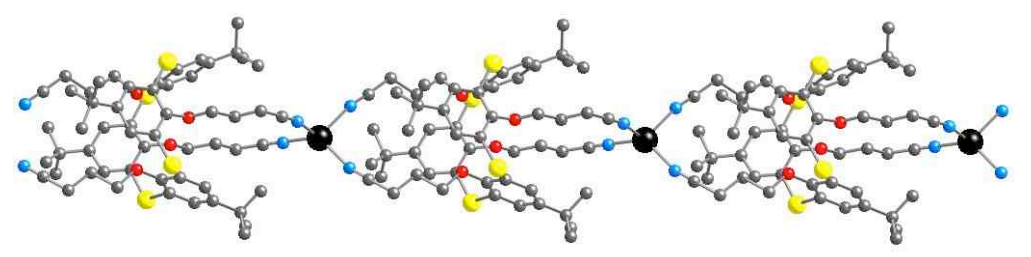

b

Figure 41: A portion of the X-ray structure showing the tetracyano $p$-tert-butyl-thiacalix[4]arene $\boldsymbol{L 4 3}$ (a) and the resulting 1D Coordination Polymer when combined with $\mathrm{Ag} *[\mathrm{Ag}(\boldsymbol{L 4 3}) \mathrm{X}] \mathrm{S}$ where $\mathrm{X}=\mathrm{SbF}_{6}, \mathrm{BF}_{4}$ and $\mathrm{PF}_{6}(\mathrm{~b})$. Black spheres represent $\mathrm{Ag}$ atoms. $\mathrm{H}$ atoms, solvent molecules and anions are not presented for sake of clarity. Adapted from Ref. [85]

Another used ligand was the tetrasubstituted benzonitrile TCA, tetrabenzonitrile $p$-tertbutyl-thiacalix[4]arene, (ligand $\mathbf{L 4 4}$, figure 42 a) in 1,3-Alternate conformation. Its combination with silver nitrate leads, in the crystalline phase to the formation of a $3 \mathrm{D}$ 
Coordination Polymer (figure 42 b) in which the organic ligands are connected by decanuclear silver nanoclusters, with a formula of $\left[\left(\mathrm{AgNO}_{3}\right)_{10}(\boldsymbol{L 4 4})\right]$ (figure $\left.42 \mathrm{c}\right)$ [86].

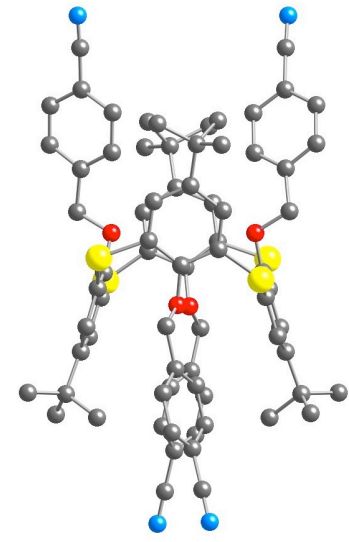

$L 44$

a

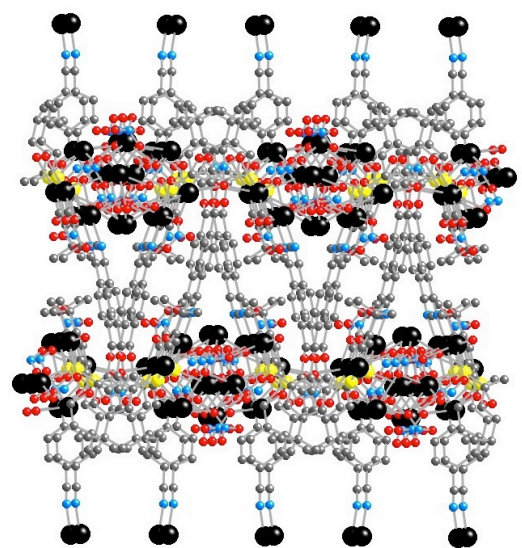

b

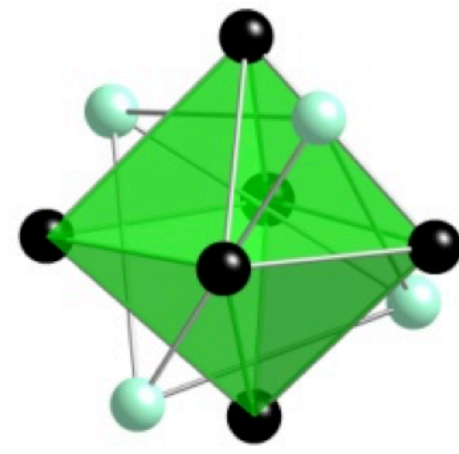

c

Figure 42: A portion of the X-ray structure showing the tetrabenzonitrile $p$-tert-butyl-thiacalix[4]arene $\mathbf{L 4 4}$ (a) and the resulting 3D network when combined with $\mathrm{AgNO}_{3}(\mathrm{~b})$ including dodecanuclear silver units $\left[\left(\mathrm{AgNO}_{3}\right)_{10}\right.$ (L44)] (c). Black (or pastel-green) spheres represent Ag atoms. H atoms and solvent molecules are not presented for sake of clarity. Adapted from Ref. [86]

\subsubsection{Carboxylate functionalization}

The first example of Coordination Polymer using TCA functionalised by carboxylate ligands was provided by Hosseini at al., using a tetraacetate $p$-H-thiacalixarene ( $\mathbf{L 4 5}$, figure 43 a), in 1,3-Alternate conformation where four appended carboxylate groups have been appended, when combined with a silver salt, it leads to a neutral 2D polymeric unit, with M/L ratio of 4/1, of formula $\left[\mathrm{Ag}_{4}(\boldsymbol{L 4 5})\left(\mathrm{CH}_{3} \mathrm{OH}\right)\left(\mathrm{H}_{2} \mathrm{O}\right)_{4}\right]$ (figure $43 \mathrm{~b}$ ) where the $\mathrm{Ag}^{+}$cations are acting as linear connectors [87]. The combination in the solid state of tetraacetate of potassium of the ligand $\mathbf{L 4 5}$ with $\mathrm{Ni}(\mathrm{II}), \mathrm{Co}(\mathrm{II})$ and $\mathrm{Zn}(\mathrm{II})$ cations afforded heteronuclear isostructural 1D Coordination Polymers of formula $\left[\mathrm{K}_{2} \mathrm{M}^{\mathrm{n}}(\boldsymbol{L 4 5})\left(\mathrm{H}_{2} \mathrm{O}\right)_{4}\left(\mathrm{CH}_{3} \mathrm{OH}\right)_{2}\right] \mathrm{S}$ (S-solvent molecules, $\mathrm{M}=\mathrm{Ni}, \mathrm{Co}, \mathrm{Zn}$ ) figure $43 \mathrm{c}$ ) [88].

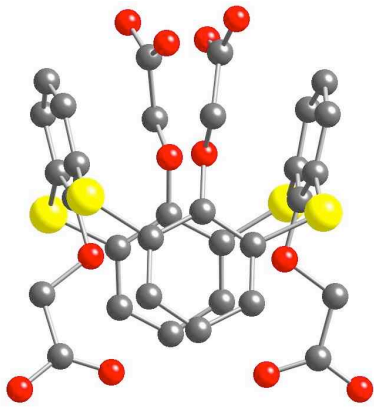

$L 45$

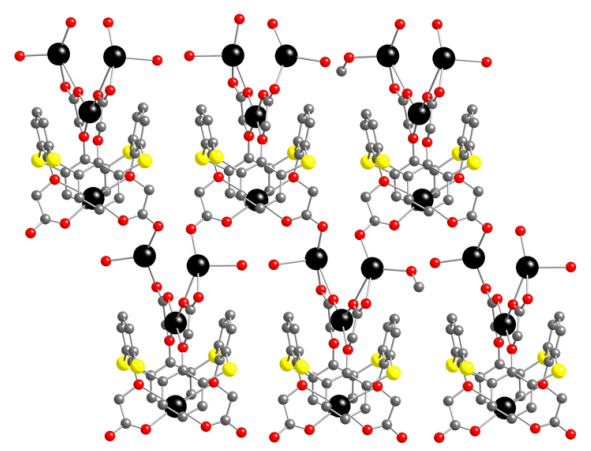

b 


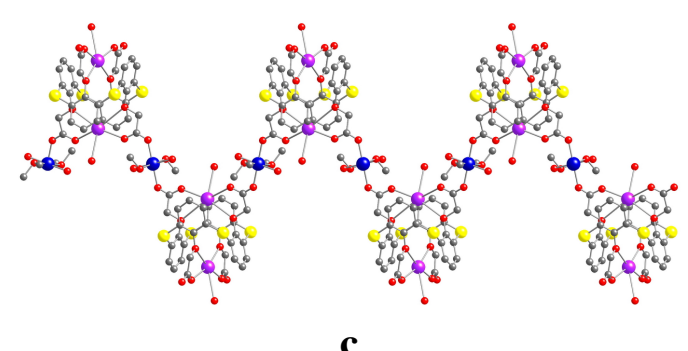

Figure 43: A portion of the X-ray structure showing the tetraacetate $p$-H-thiacalixarene in 1,3-Alternate conformation $\boldsymbol{L 4 5}$ (a), the resulting 2D network when combined with $\mathrm{Ag}_{+} \cdot\left[\mathrm{Ag}_{4}(\boldsymbol{L 4 5})\left(\mathrm{CH}_{3} \mathrm{OH}\right)\left(\mathrm{H}_{2} \mathrm{O}\right)_{4}\right]$ (b) and the

1D Coordination Polymers $\left[\mathrm{K}_{2} \mathrm{M}^{\mathrm{n}}(\boldsymbol{L 4 5})\left(\mathrm{H}_{2} \mathrm{O}\right)_{4}\left(\mathrm{CH}_{3} \mathrm{OH}\right)_{2}\right] \mathrm{S}$ (S-solvent molecules, M=Ni, Co, Zn) (c). Black, purplish-red and blue spheres represent $\mathrm{Ag}, \mathrm{K}$ and $\mathrm{Ni}$ (or $\mathrm{Co}, \mathrm{Zn}$ ) atoms, respectively. $\mathrm{H}$ atoms and solvent molecules are not presented for sake of clarity. Adapted from Ref. [87-88]

The analogous tetraacetate tert-butyl-thiacalixarene ligand $\mathbf{L 4 6}$ in 1,3-Alternate conformation (figure 44 a) has been used with ancillary ligands like 4,4'-bipyridine (bpy, figure 8), N,N'-bis(pyridine-4-yl)-isophthalamine (bppa) or diaminohexane (dah) leading, in presence of $\mathrm{Co}\left(\mathrm{NO}_{3}\right)_{2}$ or $\mathrm{Cd}\left(\mathrm{NO}_{3}\right)_{2}$ and sodium ions, to three high dimensional 3D systems of formula $\left[\mathrm{Co}_{2}(\boldsymbol{L} \mathbf{H 6})(\mathrm{bpy})\right] \quad$ (figure 4 b), $\left[\mathrm{Co}_{2}(\boldsymbol{L} \mathbf{4 6})(\mathrm{bpy})_{2}\left(\mathrm{H}_{2} \mathrm{O}\right)_{4}\right] \quad$ (figure $44 \quad$ c), $\left[\mathrm{Co}_{3} \mathrm{Na}_{2}(\boldsymbol{L 4 6})_{2}(\mathrm{bppa})_{2}\left(\mathrm{H}_{2} \mathrm{O}\right)_{2}\right](\mathrm{DMF})_{4}\left(\mathrm{H}_{2} \mathrm{O}\right)_{4} \quad$ (figure $4 \quad$ d) and $\left[\mathrm{Cd}_{2}(\boldsymbol{L 4 6})(\right.$ dah $\left.)(\mathrm{DMF})_{2}\right](\mathrm{DMF})_{2}\left(\mathrm{H}_{2} \mathrm{O}\right)_{2}[89]$. The high thermal stability of the compounds (up to $300^{\circ} \mathrm{C}$ ) has been evidenced.

Another 3D MOF, presenting gas adsorption properties, was reported by Matvieiev\& Zaworotko et al. [90]: two compounds presenting the same connectivity, of formula $\left[\mathrm{Mn}_{16}(\boldsymbol{L 4 6})_{12}\left(\left(\mathrm{CH}_{3}\right)_{2} \mathrm{NH}_{2}\right)_{16}\right] . \mathrm{S}$ (figure $44 \mathrm{e}$ ) and $\left[\mathrm{K}_{16} \mathrm{Mn}_{16}(\boldsymbol{L 4 6})_{12}\left(\left(\mathrm{CH}_{3}\right)_{2} \mathrm{NH}_{2}\right)_{16}\right] . \mathrm{S}$ (figure $44 \mathrm{f}$ ) present channels that are able to host $\mathrm{CO}_{2}$ molecules. NLO properties are also mentioned for these compounds.

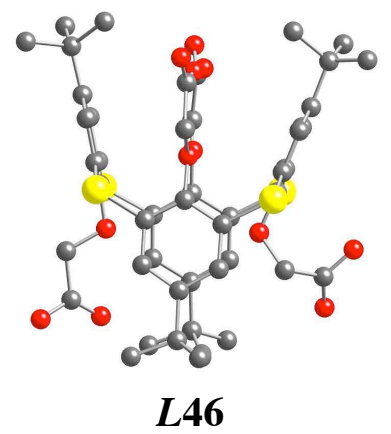

a

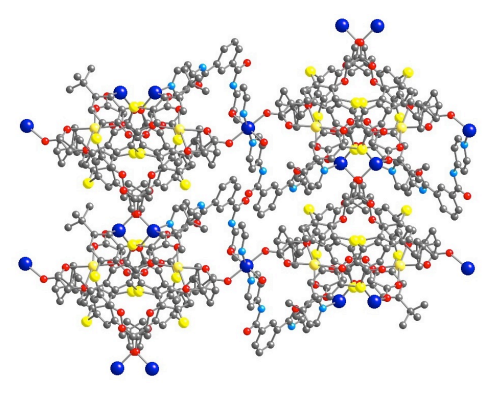

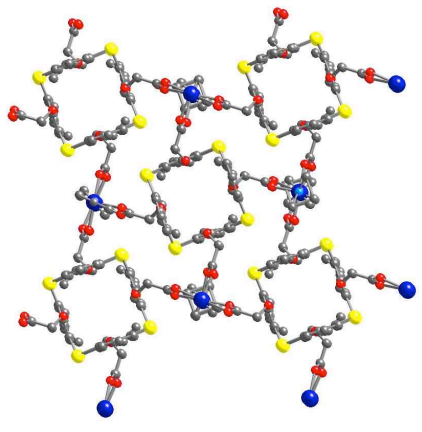

b

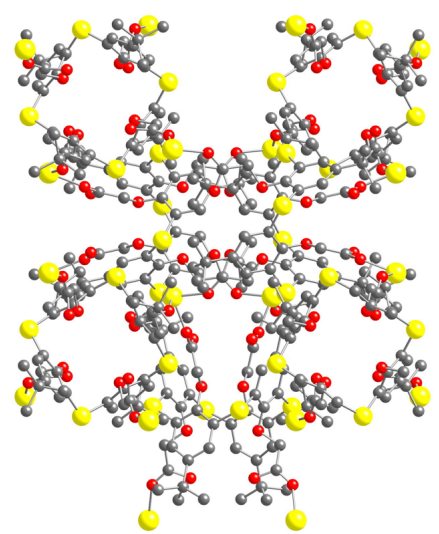

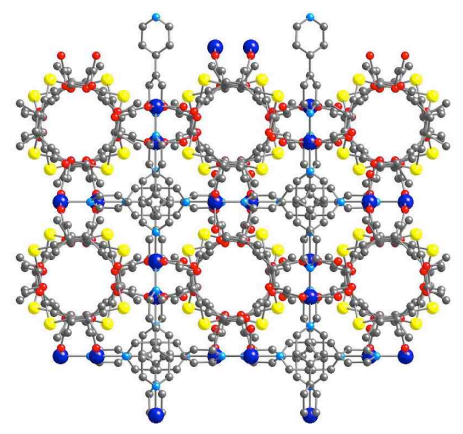

c

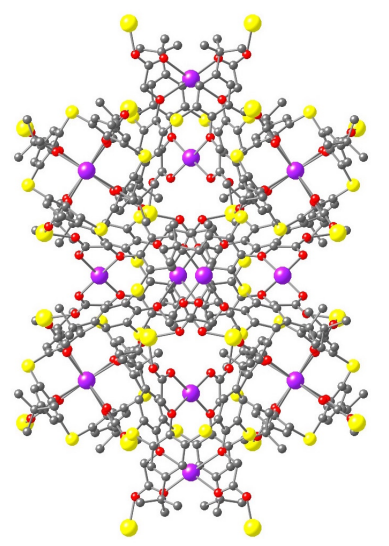


Figure 44: A portion of the X-ray structure showing the tetraacetate $p$-tert-butyl-thiacalixarene in 1,3-Alternate conformation $\boldsymbol{L 4 6}$ (a), the resulting 3D Coordination Polymers of formula $\left[\mathrm{Co}_{2}(\boldsymbol{L 4 6})(\mathrm{bpy})\right]$ (b),

$\left[\mathrm{Co}_{2}(\boldsymbol{L 4 6})(\mathrm{bpy})_{2}\left(\mathrm{H}_{2} \mathrm{O}\right)_{4}\right](\mathrm{c}),\left[\mathrm{Co}_{3} \mathrm{Na}_{2}(\boldsymbol{L} 46)_{2}(\mathrm{bppa})_{2}\left(\mathrm{H}_{2} \mathrm{O}\right)_{2}\right](\mathrm{DMF})_{(}\left(\mathrm{H}_{2} \mathrm{O}\right)_{4}(\mathrm{~d})$ a $3 \mathrm{D}$ porous Coordination Polymer

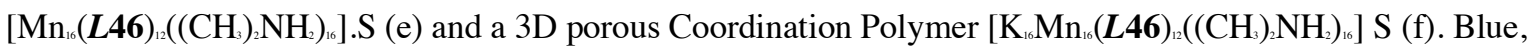
goldish, yellow and purplish-red spheres represent $\mathrm{Co}, \mathrm{Na}, \mathrm{Mn}$ and $\mathrm{K}$ atoms, respectively. $\mathrm{H}$ atoms, solvent molecules and cations are not presented for sake of clarity. Adapted from Ref. [89-90]

\subsubsection{Pyridine functionalization}

Series of pyridyl appended TCA based ligands in 1,3-Alternate conformation, that act as macrocyclic tetradentate tetrahedral ligands, were developed by Hosseini et al. .

The first series, based on the use of TCA, and playing on the different position of $\mathrm{N}$ atom on the pyridyl ring atoms (tetrapyridyl, $p$-tert-butyl-thiacalix[4]arene, ligands (L47-L49, figures 45 a-c), lead, when combined with silver cations, 2- and 3-D infinite silver Coordination Polymers. Independent of the nature of the anion, the combination of the ligand bearing $\alpha$-pyridyl appended moieties, with the $\mathrm{Ag}^{+}$cation affords an unprecedented diamond type 3D network of formula $\left[(\mathrm{AgX})_{2}(\boldsymbol{L 4 7})\right] \mathrm{S}\left(\mathrm{X}=\mathrm{SbF}_{6}, \mathrm{BF}_{4}\right.$ and $\mathrm{PF}_{6}, \mathrm{~S}=$ solvent molecules $)$ (figure 45 d). Both other ligands with $\beta$ - and $\gamma$-pyridyl ( $\boldsymbol{L} 48$ and $\boldsymbol{L} 49$, respectively) behaving as tetrakis monodentate ligands, lead to the formation of 2-D architectures of formula respectively $\left[(\mathrm{AgX})_{2}(\boldsymbol{L 4 8})\right] \mathrm{S}\left(\mathrm{X}=\mathrm{SbF}_{6}, \mathrm{BF}_{4}\right.$ and $\left.\mathrm{PF}_{6}\right)$ (figure 45 e) and $\left[\mathrm{AgPF}_{6}(\boldsymbol{L 4 9}) \mathrm{DMF}\right]$ $\mathrm{CHCl}_{3} \mathrm{DMF} \mathrm{MeOH}$ (figure $45 \mathrm{f}$ ) [91].

Tetrahedral $\mathbf{L 4 7}$ was also combined with octahedral $\mathrm{CdX}_{2}(\mathrm{X}=\mathrm{Cl}$ or $\mathrm{Br})$ [92] or $\mathrm{Fe}(\mathrm{NCS})_{2}$ [93] metal nodes, that behave like square planar connectors, leading to pseudo diamond Coordination Polymers of formula $\left[\mathrm{CdBr}_{2}(\boldsymbol{L 4 7})\right]\left(\mathrm{CHCl}_{3}\right)_{4} \quad$ (figure $45 \mathrm{~g}$ ) or $\left[\mathrm{Fe}(\mathrm{NCS})_{2}(\boldsymbol{L 4 8})\right]\left(\mathrm{CHCl}_{3}\right)_{5}($ figure $44 \mathrm{~h})$.

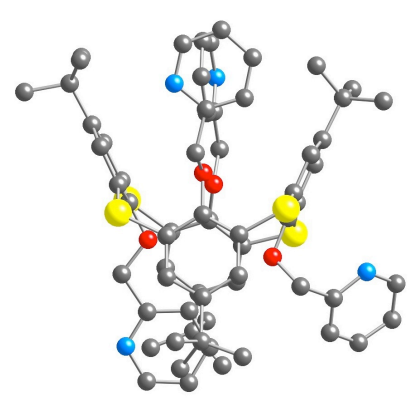

L47

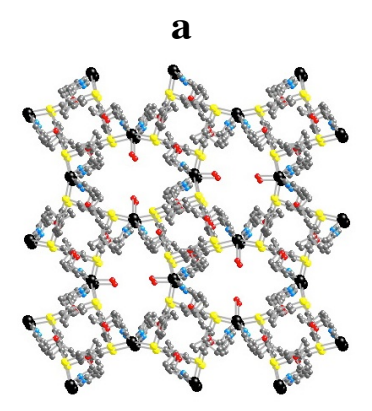

d

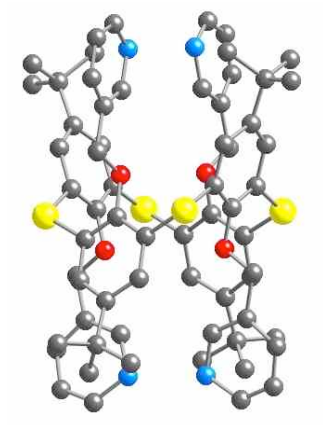

$L 48$

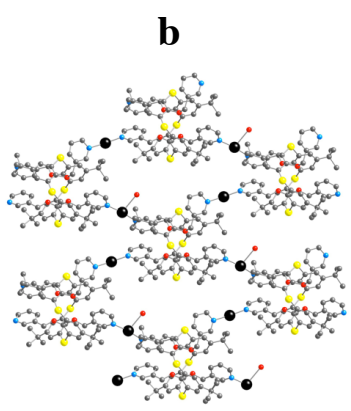

e

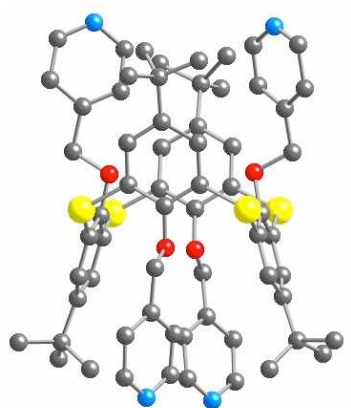

L49

c

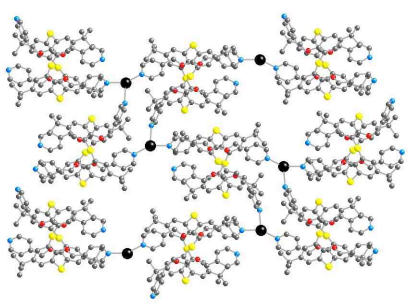

f 


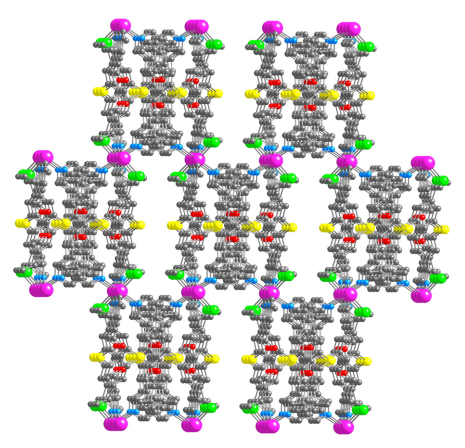

g

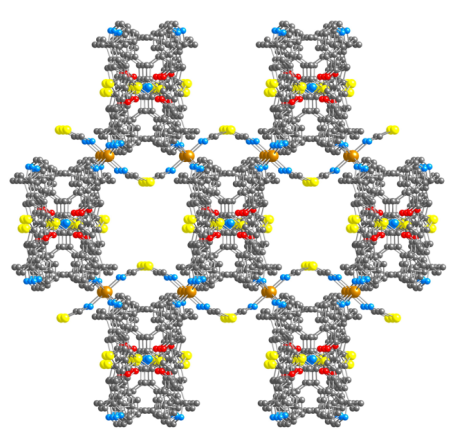

h

Figure 45: A portion of the X-ray structure showing the pyridyl appended p-tert-butylthiacalix[4]arenes $\mathbf{L 4 7 - \boldsymbol { L } 4 9}$ (a-c) in 1,3-Alternate conformation, together with their corresponding Coordination Polymers when combined with $\mathrm{AgX}$ : A diamond-like Coordination Polymer of formula $\left[(\mathrm{AgX})_{2}(\boldsymbol{L 4 7})\right] \mathrm{S}\left(\mathrm{X}=\mathrm{SbF}_{6}, \mathrm{BF}_{4}\right.$ and $\left.\mathrm{PF}_{6}\right)(\mathrm{d})$, a 2D

system of formula $\left[(\mathrm{AgX})_{2}(\boldsymbol{L 4 8})\right] \mathrm{S}\left(\mathrm{X}=\mathrm{SbF}_{6}, \mathrm{BF}_{4}\right.$ and $\left.\mathrm{PF}_{6}\right)(\mathrm{e})$, a $2 \mathrm{D}$ Coordination Polymer of formula

$\left[\mathrm{AgPF}_{6}(\boldsymbol{L 4 9}) \mathrm{DMF}\right] \mathrm{CHCl}_{3} \mathrm{DMF} \mathrm{MeOH}(\mathrm{f})$, the $3 \mathrm{D}$ diamondoid $\left[\mathrm{CdBr}_{2}(\boldsymbol{L 4 8})\right]\left(\mathrm{CHCl}_{3}\right)_{4}(\mathrm{~g})$ and the $3 \mathrm{D}$ diamondoid $\left[\mathrm{Fe}(\mathrm{NCS})_{2}(\boldsymbol{L 4 8})\right]\left(\mathrm{CHCl}_{3}\right)_{s}(\mathrm{~h})$. Black, Purplish-red and brown spheres represent $\mathrm{Ag}, \mathrm{Cd}$ and $\mathrm{Fe}$ atoms, respectively. $\mathrm{H}$ atoms, solvent molecules and anions are not presented for sake of clarity. Adapted from Ref. [9193]

The second series, based on the use of pyridyl appended $p$-H-thiacalix[4]arene (tetrapyridyl, $p$ - $H$-thiacalix[4]arene, (ligands $\mathbf{L 5 0 - L 5 2}$, figures 46 a-c) and as in the previous case, leading to three new positional isomers, that present a less deformed shape than their $p$ tert-butyl-thiacalix[4]arene analogues. The neutral tetradentate ligands have been combined with $\mathrm{HgCl}_{2}$ leading to the formation of 1-, 2- and 3D neutral mercury Coordination Polymers. Whereas for the $\alpha$-isomer a 2D architecture results from the bridging of consecutive ligands connected by the mononuclear $\mathrm{HgCl}_{2}$ unit, of formula $\left[\mathrm{Hg}_{2} \mathrm{Cl}_{4}(\boldsymbol{L 5 0})\right]$ [94], (figure $46 \mathrm{~d}$ ) is obtained, for the $\beta$-isomer, again a $2 \mathrm{D}$ network is formed, the interconnection of consecutive ligands taking place through a binuclear $\mathrm{Hg}_{2} \mathrm{Cl}_{4}$ species, with a polymer of formula $\left[\mathrm{Hg}_{4} \mathrm{Cl}_{8}(\boldsymbol{L 5 1})_{2}\right] \mathrm{H}_{2} \mathrm{O}\left(\mathrm{CH}_{3} \mathrm{OH}\right)_{2}\left(\mathrm{CHCl}_{3}\right)_{2}$ (figure 46 e) and together with a $3 \mathrm{D}$ diamond-like compound of formula $\left[\mathrm{Hg}_{3} \mathrm{Cl}_{6}(\boldsymbol{L 5 1})_{2}\right]\left(\mathrm{CHCl}_{3}\right)_{2}$, where only three of the pyridyl units are involved in the formation of the 3D system (figure $46 \mathrm{~g}$ ) [95]. Finally, in the case of the $\gamma$ isomer, a $1 \mathrm{D}$ ribbon type double chain arrangement resulting from the bridging of consecutive ligands by trinuclear $\mathrm{Hg}_{3} \mathrm{Cl}_{6}$ units followed by the interconnection of two chains through the fusion of the trinuclear centres into a hexanuclear node is observed, with the following formula $\left[\mathrm{Hg}_{3} \mathrm{Cl}_{6}(\mathbf{L 5 2})\right]\left(\mathrm{CHCl}_{3}\right)_{127}$ [94] (figure $46 \mathrm{f}$ ), together with a 1D tubular type compound of formula $\left[\mathrm{Hg}_{2} \mathrm{Cl}_{4}(\boldsymbol{L 5 2})\right]\left(\mathrm{CHCl}_{3}\right)_{4}$ (figure $46 \mathrm{~h}$ ), where $\mathrm{Hg}_{2} \mathrm{Cl}_{4}$ metal nodes are acting as $\mathrm{V}$ shape connectors between the $\boldsymbol{L 5 2}$ ligand [95]. The association of $\boldsymbol{L 5 2}$ with $\mathrm{Fe}(\mathrm{NCS})_{2}$ leads to a grid-like $2 \mathrm{D}$ system of formula $\left[\mathrm{Fe}(\mathrm{NCS})_{2}(\mathbf{L 5 2})\right]\left(\mathrm{CHCl}_{3}\right)_{0.66}$ where $\mathrm{Fe}(\mathrm{NCS})_{2}$ metal cores act as square connectors (figure $45 \mathrm{i}$ ) [93]. 


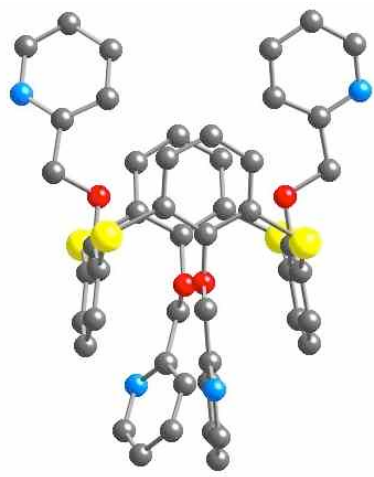

L50

a

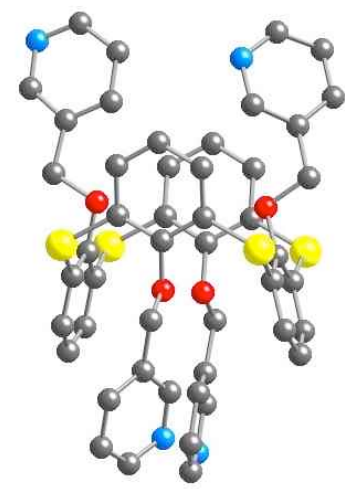

L51

b

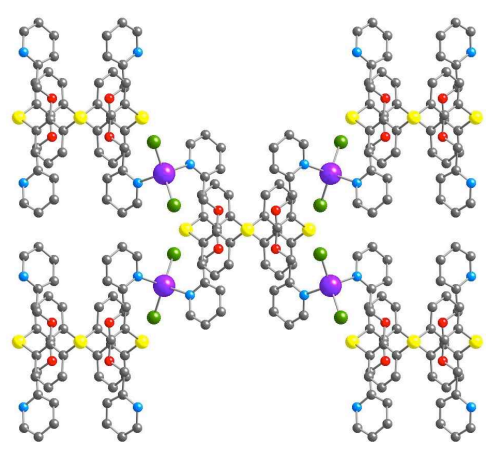

d

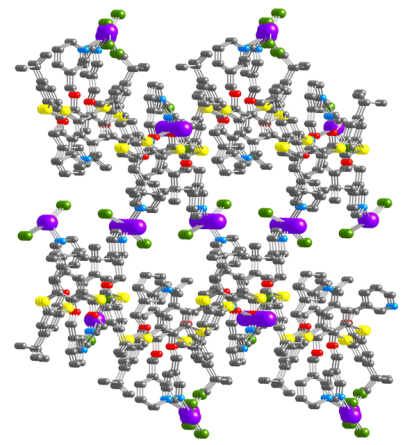

g

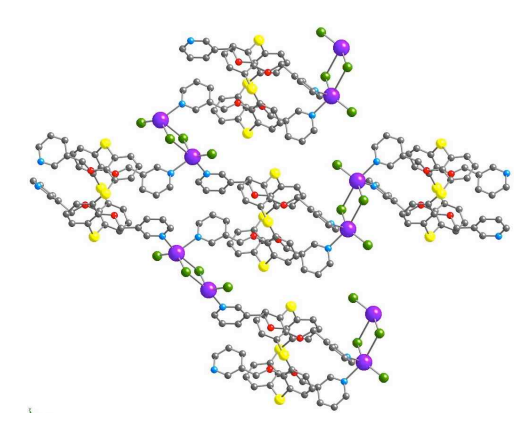

e

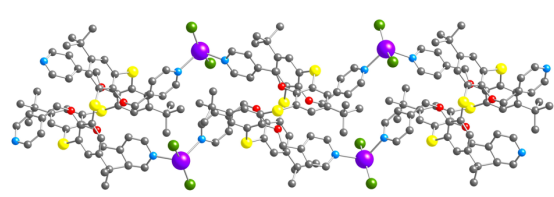

h

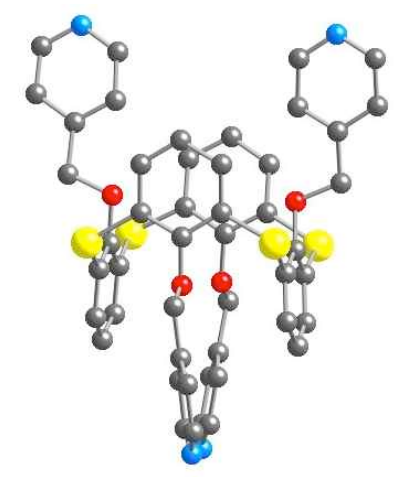

L52

c

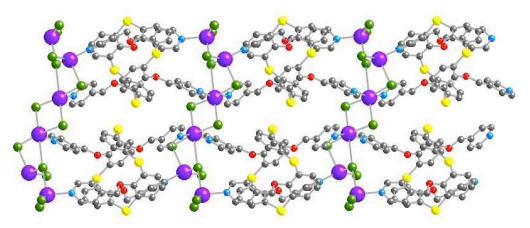

f

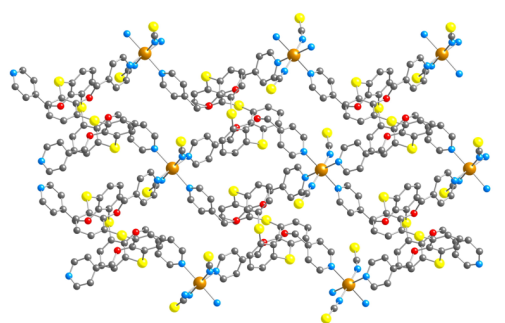

i

Figure 46: A portion of the X-ray structure showing the pyridyl appended $p$-H-thiacalix[4]arene $\mathbf{L 5 0}-\mathbf{L 5 2}$ (a-c) in 1,3-Alternate conformation, together with their corresponding Coordination Polymers when combined with $\mathrm{HgCl}_{2}$ : a 2D Coordination Polymer of formula $\left[\mathrm{Hg}_{2} \mathrm{Cl}_{(}(\boldsymbol{L 5 0})\right]$ (d), a 2D system of formula

$\left[\mathrm{Hg}_{4} \mathrm{Cl}_{8}(\boldsymbol{L 5 1})_{2}\right] \mathrm{H}_{2} \mathrm{O}\left(\mathrm{CH}_{3} \mathrm{OH}\right)_{2}\left(\mathrm{CHCl}_{3}\right)_{2}$ (e), a 1D double ribbon-like Coordination Polymer of formula $\left[\mathrm{Hg}_{3} \mathrm{Cl}_{6}(\boldsymbol{L 5 2})\right]\left(\mathrm{CHCl}_{3}\right)_{1.27}$ (f), a $3 \mathrm{D}$ system $\left[\mathrm{Hg}_{0} \mathrm{Cl}_{6}(\boldsymbol{L 5 1})_{2}\left(\mathbf{C H C l}_{3}\right)_{2}\right](\mathrm{g})$, a $1 \mathrm{D}$ tubular type Coordination Polymer of formula $\left[\mathrm{Hg}_{2} \mathrm{Cl}_{(}(\boldsymbol{L 5 2})\right]\left(\mathrm{CHCl}_{3}\right)_{4}$ (h) and a 2D system of formula $\left[\mathrm{Fe}(\mathrm{NCS})_{2}(\boldsymbol{L 5 2})\right]\left(\mathrm{CHCl}_{3}\right)_{\circ \infty}(\mathrm{i})$. Violet spheres represent $\mathrm{Hg}$ atoms. $\mathrm{H}$ atoms, solvent molecules and anions are not presented for sake of clarity. Adapted from Ref. [93-95]

\subsubsection{Pyrazolyl functionalization}

Along this line, the coordination ability of analogous pyrazolyl appended TCA based ligands in 1,3-Alternate conformation towards $\mathrm{Ag}(\mathrm{I})$ cations were investigated by Hosseini et al..

The first series is based on the use O-propylpyrazolyl appended p-tert-butylthiacalix[4]arene ligands $\boldsymbol{L 5 3}$ (figure 47 a) combined with silver cations. The combination leads to Coordination Polymers presenting the same connectivity, and already well-known 
non-tubular like shape [85], with the following formula $\left[\mathrm{Ag}(\boldsymbol{L 5 3}) \mathrm{BF}_{4}\right] \quad\left(\mathrm{H}_{2} \mathrm{O}\right)_{3}$ (or $\left[\mathrm{Ag}(\boldsymbol{L 5 3}) \mathrm{SbF}_{6}\right]\left(\mathrm{CHCl}_{3}\right)$ (figure 47 b) [96].

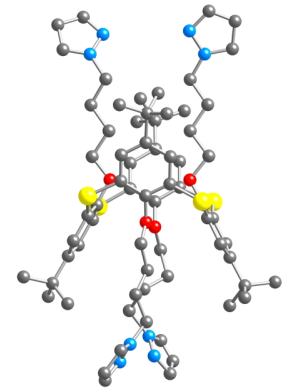

$L 53$

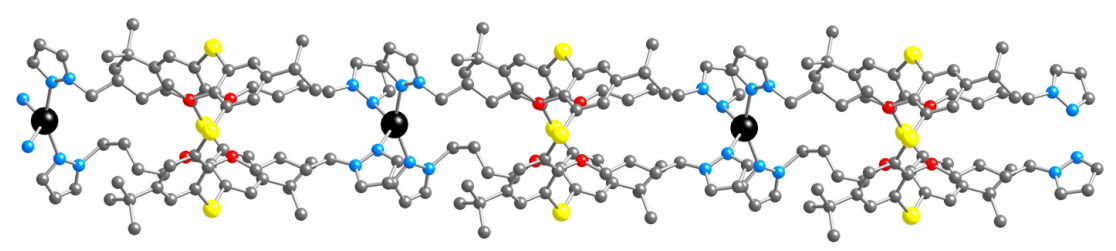

a

b

Figure 47: A portion of the X-ray structure showing propane-pyrazolyl appended $p$-tert-butyl-thiacalix[4]arene $\boldsymbol{L 5 3}$ (a) and the resulting $1 \mathrm{D}$ network when combined with $\mathrm{Ag} \cdot[\mathrm{Ag}(\boldsymbol{L 5 3}) \mathrm{X}] \mathrm{S}$ where $\mathrm{X}=\mathrm{SbF}_{6}$ or $\mathrm{BF}_{4}$ and $\mathrm{S}$ are solvent molecules. Only compound with $\mathrm{X}=\mathrm{BF}_{4}$ is presented (b). Black spheres represent $\mathrm{Ag}$ atoms. $\mathrm{H}$ atoms, solvent molecules and anions are not presented for sake of clarity. Adapted from Ref. [96]

\subsubsection{TMTCA based Coordination Polymers}

This strategy of functionalization has also been applied to sulphur derivatives of TCA: the TMTCA (tetramercaptothiacalixarene) [10], where the phenoxyl groups have been replaced by thioether groups, increasing the coordination abilities of the ligands, because of the presence of eight sulphur atom in molecular scaffold.

To date, only very few Coordination Polymers arising from this family of compounds have been described, and only Hosseini's et al. has developed this type of new ligands, and, for most of them, they are analogous to the reported one for TCA.

\subsubsection{Cyano functionalization}

Two tetradentate ligands in 1,3-Alternate conformation, bearing cyano coordinating groups were obtained ( $\mathbf{L 5 4}$ and $\mathbf{L 5 5}$, figure 48 a and c), leading to a non tubular 1D system with a $1 / 1$ ratio of formula $\left[\operatorname{Ag}(\boldsymbol{L 5 4}) \mathrm{PF}_{6}\right]$ when combined to $\operatorname{AgPF}_{6}$ (figure $48 \mathrm{~b}$ ) [97]. This is an interesting coordination mode, since, in this case, silver atoms of the ring of the macrocycle enter into the coordination sphere of the silver cation, and consequently, some pendant cyano are non-bridging. The combination of the less flexible $\mathbf{L 5 5}$ with $\mathrm{AgPF}_{6}$ leads to the formation of a 3D diamond-like Coordination Polymers of formula $\left[\left(\mathrm{AgPF}_{6}\right)_{8}(\mathbf{L 5 5})_{4}\right.$ $\left.\left(\mathrm{CH}_{3} \mathrm{OH}\right)\right]\left(\mathrm{CH}_{3} \mathrm{OH}\right)_{4}\left(\mathrm{CHCl}_{3}\right)_{4}$ (figure $48 \mathrm{c}$ ).

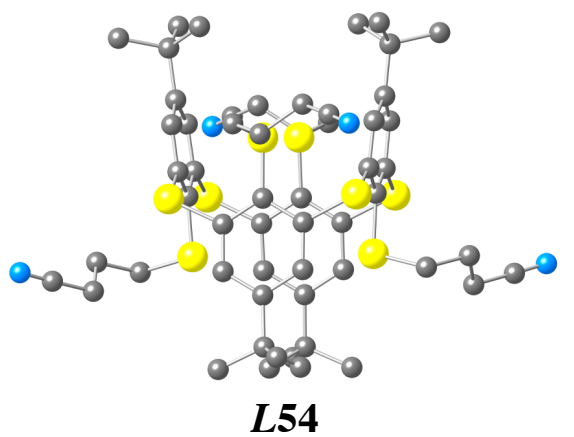

a

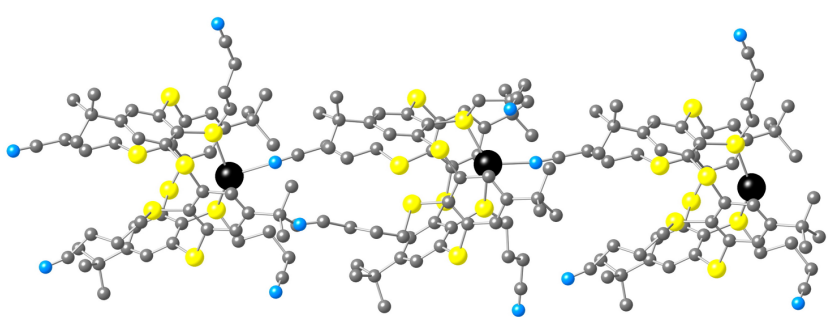

b 


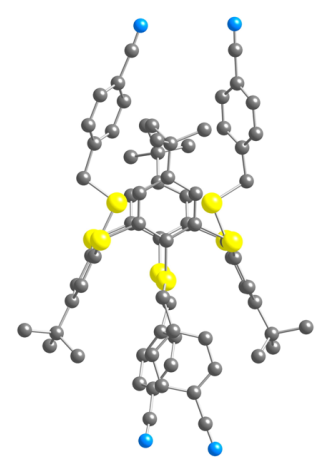

L55

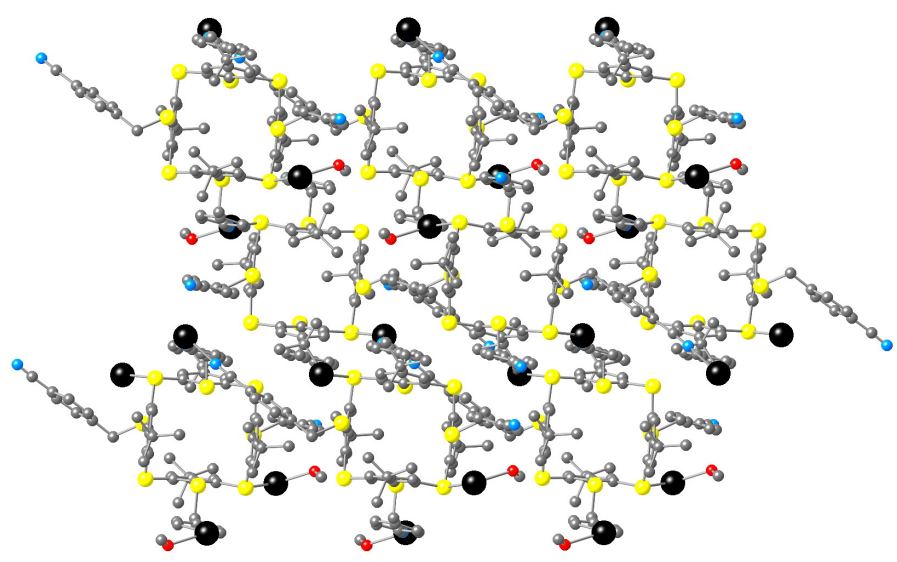

d

Figure 48: A portion of the X-ray structure showing the cyano appended tetramercaptotetrathiacalix[4]arene (L54-L55) (a and c) in 1,3-Alternate conformation, together with their corresponding Coordination Polymers when combined with $\mathrm{AgPF}_{6}$ : a 1D network of formula $\left[\mathrm{Ag}(\boldsymbol{L 5 4}) \mathrm{PF}_{6}\right]$ (b) and a diamond-like 3D Coordination Polymer of formula $\left[\left(\mathrm{AgPF}_{6}\right)_{(}(\mathbf{L 5 5})_{i}\left(\mathrm{CH}_{3} \mathrm{OH}\right)\right]\left(\mathrm{CH}_{3} \mathrm{OH}\right)_{i}\left(\mathrm{CHCl}_{3}\right)_{4}(\mathrm{~d})$. Black spheres represent Ag atoms. $\mathrm{H}$ atoms, solvent molecules and anions are not presented for sake of clarity. Adapted from Ref. [97]

\subsubsection{Carboxylate functionalization}

The first coordination networks based on tetramercaptotetrathiacalix[4]arene carboxylate-appended coordinating group was provided when $\mathbf{L 5 6}$ (figures 49 a) is combined with Zinc(II) acetate and Copper(II) (Manganese(II)), leading to 1D coordination networks of formula $\left[(\boldsymbol{L 5 6})\left(\mathrm{Zn}(\mathrm{py})_{2}\right)_{2}\right](\text { py })_{7}$ (figures $\left.49 \mathrm{~b}\right)$ and $\left[(\boldsymbol{L} \mathbf{5 6})\left(\mathrm{M}(\mathrm{py})_{2}\left(\mathrm{OH}_{2}\right)\right]_{2}(\mathrm{py})_{2}(\mathrm{M}=\mathrm{Cu}\right.$ or $\mathrm{Mn})$ (figure 49 c) [98]. Due to the different coordination environment of the metals, 1D coordination networks are either linear $(\mathrm{M}=\mathrm{Cu}$ or $\mathrm{Mn})$ or zigzag $(\mathrm{M}=\mathrm{Zn})$.

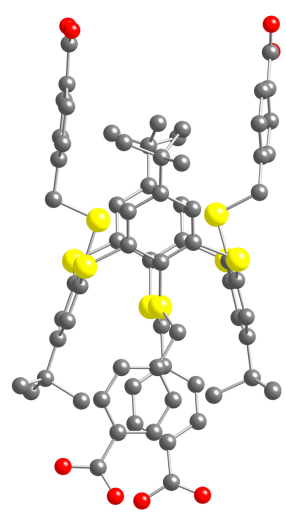

$L 56$

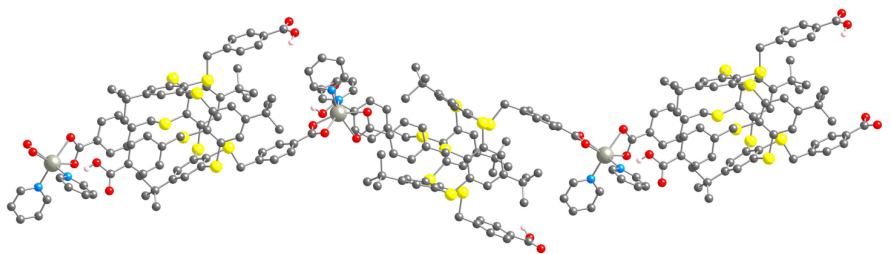

b

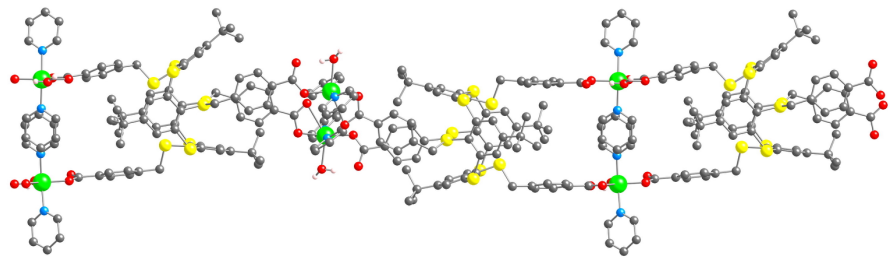

c

Figure 49: A portion of the X-ray structure showing the tetramercaptotetrathiacalix[4]arene carboxylateappended $\boldsymbol{L} 56$ in 1,3-Alternate conformation (a), together with its corresponding Coordination Polymers when combined with $\mathrm{Zn}(\mathrm{OAc})_{2}$, leading to a zigzag chain of formula $\left[(\boldsymbol{L 5 6})\left(\mathrm{Zn}(\mathrm{py})_{2}\right]_{2}(\mathrm{py})_{)_{2}}(\mathrm{~b})\right.$ and combined with $\mathrm{Cu}(\mathrm{OAc})_{2}$, (or $\mathrm{Mn}(\mathrm{OAc})_{2}$,) salts leading to the linear chain (c). Grey and green spheres represent $\mathrm{Zn}$ and $\mathrm{Cu}$ atoms, respectively. $\mathrm{H}$ atoms, solvent molecules and anions are not presented for sake of clarity. Adapted from Ref. [98] 


\subsubsection{Pyridine functionalization}

The first Coordination Polymer based on tetramercaptotetrathiacalix[4]arene pyridylappended positional isomers (ligands $\boldsymbol{L}$ 57- $\mathbf{L 5 9}$, figures 50 a-c) combined with $\mathrm{HgCl}_{2}$ lead to the formation of neutral Coordination Polymers with their dimensionality imposed by the position of the $\mathrm{N}$ atom on the pyridyl group. The $\alpha$-isomer $\mathbf{L 5 7}$ leads to the formation of a diamond-like 3D Coordination Polymer of formula $\left[\mathrm{Hg}_{4} \mathrm{Cl}_{8}(\boldsymbol{L 5 7})\right]\left(\mathrm{CHCl}_{3}\right)_{2}$ (figure $50 \mathrm{~d}$ ), the $\beta$ isomer $\boldsymbol{L 5 8}$ generates a 2D assembly of formula $\left[\mathrm{Hg}_{2} \mathrm{Cl}_{4}(\boldsymbol{L 5 8})_{2}\right]$ (figure $50 \mathrm{e}$ ) and finally, the $\gamma-$ isomer $\boldsymbol{L 5 9}$ affords a $1 \mathrm{D}$ network of formula $\left[\mathrm{Hg}_{2} \mathrm{Cl}_{4}(\boldsymbol{L 5 9})\right]\left(\mathrm{CHCl}_{3}\right)_{2}$ (figure 50 f) [99].

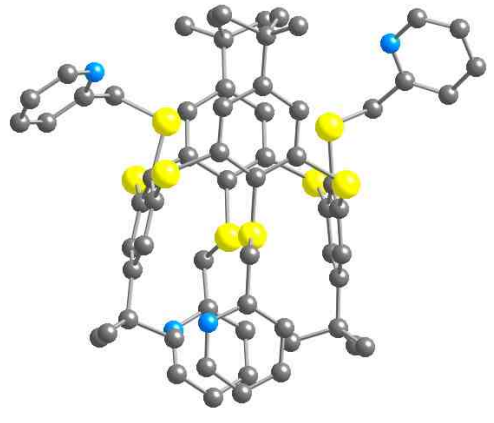

$L 57$

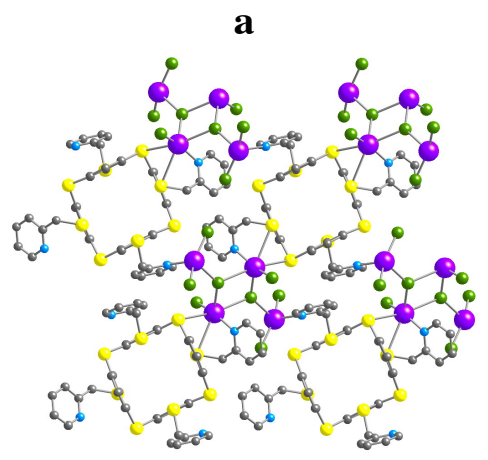

d

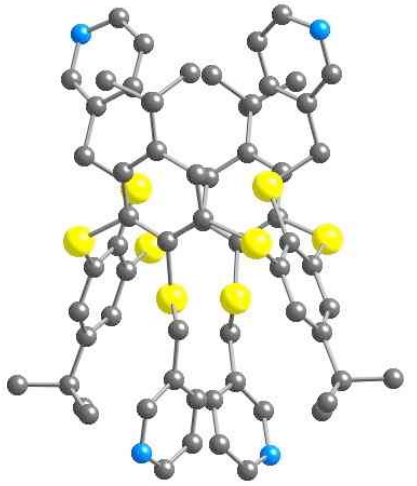

$L 58$

b

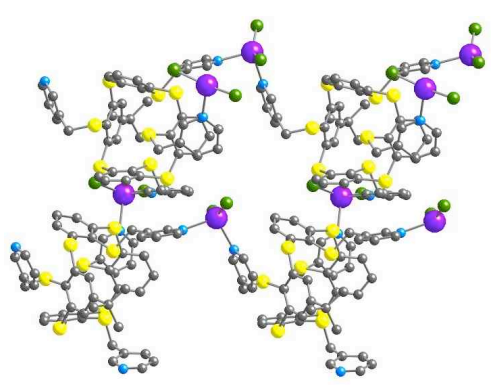

e

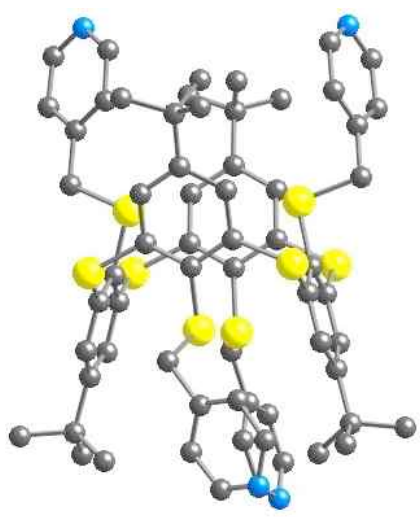

L59

c

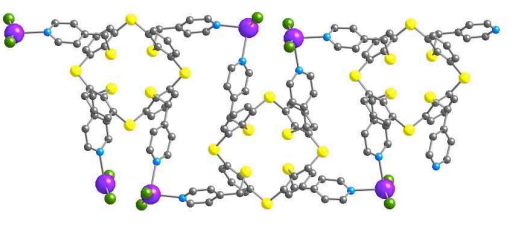

f

Figure 50: A portion of the X-ray structure showing the pyridyl appended tetramercaptotetrathiacalix[4]arene L57-L59 (a-c) in 1,3-Alternate conformation, together with their corresponding Coordination Polymers when combined with $\mathrm{HgCl}_{2}$ : a diamond-like 3D Coordination Polymer of formula $\left[\mathrm{Hg}_{4} \mathrm{Cl}_{s}(\boldsymbol{L 5 7})\right]\left(\mathrm{CHCl}_{3}\right)_{2}(\mathrm{~d})$, a $2 \mathrm{D}$ system of formula $\left[\mathrm{Hg}_{2} \mathrm{Cl}_{(}(\boldsymbol{L 5 8})_{2}\right]$ (e) and a 1D network of formula $\left[\mathrm{Hg}_{2} \mathrm{Cl}_{i}(\boldsymbol{L 5 9})\right]\left(\mathrm{CHCl}_{3}\right)_{2}$ (f). Violet spheres represent $\mathrm{Hg}$ atoms. $\mathrm{H}$ atoms, solvent molecules and anions are not presented for sake of clarity. Adapted from Ref. [99]

As in the case with TCA, tetrahedral $\mathbf{L 5 8}$ (figure 50 b) was also combined with octahedral metal nodes, that behave like square planar connectors, leading to a pseudo diamond 3D compounds: for example with $\mathrm{CdBr}_{2}$, a compound of formula $\left[\mathrm{CdBr}_{2}(\boldsymbol{L 5 8})\right]\left(\mathrm{CHCl}_{3}\right)_{2}$ (figure 51 a) was obtained, with $\mathrm{FeCl}_{2}$ affording a compound of formula $\left[\mathrm{FeCl}_{2}(\boldsymbol{L 5 8})\right] \mathrm{CH}_{3} \mathrm{OH}$ (figure $51 \mathrm{~b}$ ) and with $\mathrm{CoX}_{2}(\mathrm{X}=\mathrm{Cl}$ or $\mathrm{Br})$ a $2 \mathrm{D}$ network of formula $\left[\mathrm{CoX}_{2}(\boldsymbol{L 5 8})\right]\left(\mathrm{CH}_{3} \mathrm{OH}\right)_{2} \mathrm{H}_{2} \mathrm{O}$ have been obtained (figure 51 c) [92]. The combination of $\boldsymbol{L 5 8}$ with $\mathrm{Fe}(\mathrm{NCS})_{2}$ leads to a 3D system of formula $\left[\mathrm{Fe}(\mathrm{NCS})_{2}(\boldsymbol{L 5 8})\right]\left(\mathrm{H}_{2} \mathrm{O}\right)_{2}$ (figure $51 \mathrm{~d}$ ) [93]. 


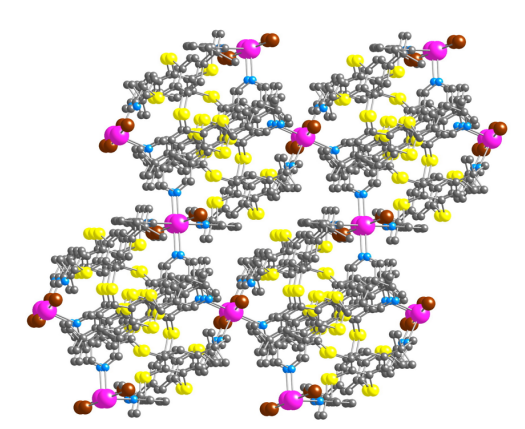

a

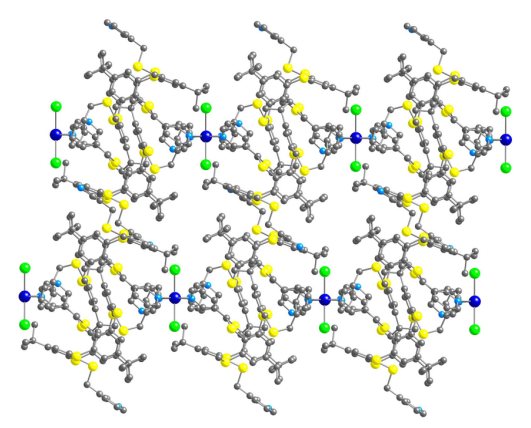

c

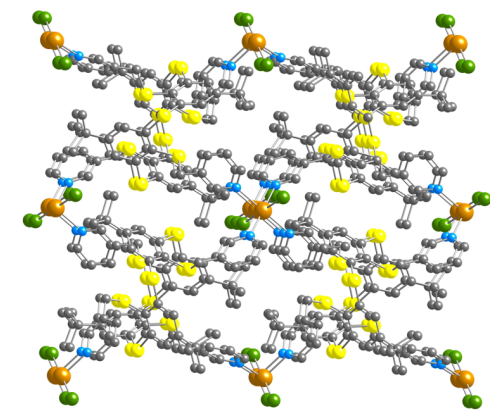

b

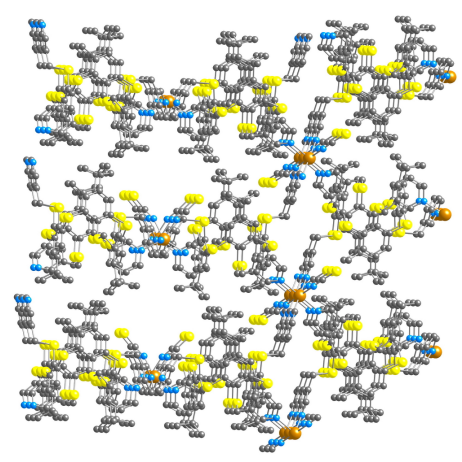

d

Figure 51: A portion of the X-ray structure showing the pyridyl appended tetramercaptotetrathiacalix[4]arene $\mathbf{L 5 8}$ (figure 50 b) in 1,3-Alternate conformation combined with $\mathrm{MX}_{2}$ metal nodes, that behave like square planar connectors, leading to a of pseudo diamond like 3D structure $\left[\mathrm{CdBr}_{2}(\boldsymbol{L 5 8})\right]\left(\mathrm{CHCl}_{3}\right)_{2}$ (a), $3 \mathrm{D}\left[\mathrm{FeCl}_{2}(\boldsymbol{L 5 8})\right] \mathrm{CH}_{3} \mathrm{OH}$ (b), $2 \mathrm{D}\left[\mathrm{CoBr} r_{2}(\boldsymbol{L 5 8})\right]\left(\mathrm{CH}_{3} \mathrm{OH}\right)_{2} \mathrm{H}_{2} \mathrm{O}(\mathrm{c})$ and $3 \mathrm{D}\left[\mathrm{Fe}(\mathrm{NCS})_{2}(\boldsymbol{L 5 8})\right]\left(\mathrm{H}_{2} \mathrm{O}\right)_{2}$ (d). Purplish-red, brown and dark-blue spheres represent $\mathrm{Cd}, \mathrm{Fe}$ and $\mathrm{Co}$ atoms, respectively. $\mathrm{H}$ atoms and solvent molecules are not presented for sake of clarity. Adapted from Ref. [92-93]

When tetrahedral $\mathbf{L 5 8}$ (figure 50 b) was combined with silver cations, different Coordination Polymers depending of the type of used silver salt were also obtained.

For example, the combination of $\mathbf{L 5 8}$ with $\mathrm{AgBF}_{4}$ leads to a non tubular 1D Coordination Polymer of formula $\left[\mathrm{AgBF}_{4}(\boldsymbol{L 5 8})\right]$ (figure 52 a), whereas the combination with $\mathrm{AgNO}_{3}$ leads to a tubular 1D Coordination Polymer of formula $\left[\left(\mathrm{AgNO}_{3}\right)_{2}(\boldsymbol{L 5 8})\right]$ (figure $52 \mathrm{~b}$ ) and finally the combination with $\mathrm{AgSbF}_{6}$ leads to a chiral porous 3D Coordination Polymer of formula $\left[\left(\mathrm{AgSbF}_{6}\right)_{2}(\boldsymbol{L 5 8})\right]$ (figure $\left.58 \mathrm{c}\right)$ [100].

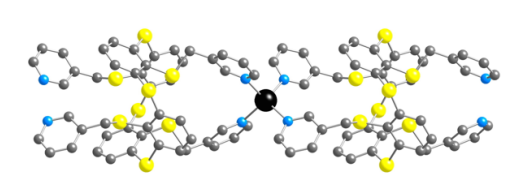

a

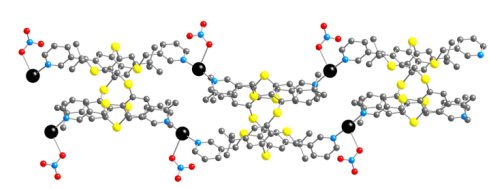

b

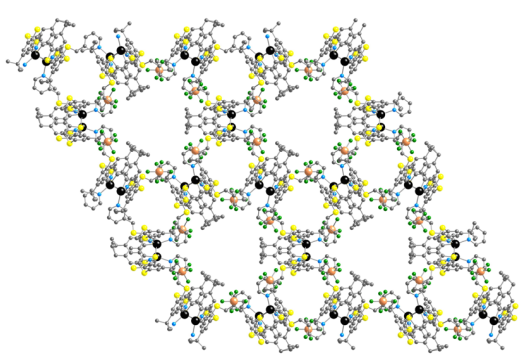

c

Figure 52: A portion of the X-ray structure showing the pyridyl appended tetramercaptotetrathiacalix[4]arene ( $\boldsymbol{L 5 8}$, figure 50 b) in 1,3-Alternate conformation combined with silver cations; non tubular 1D Coordination Polymer of formula $\left[\mathrm{AgBF}_{4}(\boldsymbol{L 5 8})\right]$ (a), tubular 1D Coordination Polymer of formula $\left[\left(\mathrm{AgNO}_{3}\right)_{2}(\boldsymbol{L 5 8})\right]$ (b) and chiral porous 3D Coordination Polymer of formula $\left[\left(\mathrm{AgSbF}_{6}\right)_{2}(\boldsymbol{L 5 8})\right](\mathrm{c})$. Black spheres represent $\mathrm{Ag}$ atoms. $\mathrm{H}$ atoms, solvent molecules and anions are not presented for sake of clarity. Adapted from Ref. [100] 
As in the previous case with TCA, series of alkyl-pyrazolyl appended p-tert-butyltetramercaptotetrathiacalix[4]arene ligands L60-L62 (ethyl, propyl and butyl spacers have been used, figure 53 a-c) combined with silver cations [96]. The combination of $\boldsymbol{L 6 0}$ with $\mathrm{AgX}$ salts where $\mathrm{X}=\mathrm{SbF}_{6}, \mathrm{AsF}_{6}$ and $\mathrm{PF}_{6}$ leads to a series of isostructural diamond like Coordination Polymers of $\left[(\mathrm{AgX})_{2}(\boldsymbol{L 6 0})\right]\left(\mathrm{H}_{2} \mathrm{O}\right)_{3}\left(\mathrm{X}=\mathrm{SbF}_{6}, \mathrm{AsF}_{6}\right.$ and $\left.\mathrm{PF}_{6}\right)$ where silver is in a tetrahedral environment (figure $53 \mathrm{~d}$ ). Whereas the combination of the same ligand with $\mathrm{AgBF}_{4}$ leads to the formation of a $2 \mathrm{D}$ system of formula $\left[\left(\mathrm{AgBF}_{4}\right)_{2}(\boldsymbol{L 6 0})\right]\left(\mathrm{H}_{2} \mathrm{O}\right)_{0.5}$ where the geometry around silver atoms is closer to square planer (figure $53 \mathrm{e}$ ). The combination of the more flexible ligand $\boldsymbol{L 6 1}$ with $\mathrm{AgSbF}_{6}$ gives rise to the formation of a $1 \mathrm{D}$ system non tubular system of formula $\left[\left(\mathrm{AgSbF}_{6}\right)_{2}(\mathbf{L 6 1})\right]\left(\mathrm{CHCl}_{3}\right)_{2}$ (figure $53 \mathrm{f}$ ). The combination of the ligand bearing the longest chain, $\mathbf{L 6 2}$ with $\mathrm{AgSbF}_{6}$ leads to the formation of a $2 \mathrm{D}$ system of formula $\left[\left(\mathrm{AgSbF}_{6}\right)_{2}(\boldsymbol{L 6 2})\right]\left(\mathrm{CHCl}_{3}\right)_{35}\left(\mathrm{H}_{2} \mathrm{O}\right)$ (figure $\left.53 \mathrm{~g}\right)$ and its combination with $\mathrm{AgNO}_{3}$ leads to the formation of a $1 \mathrm{D}$ system of formula $\left[\left(\mathrm{AgNO}_{3}\right)_{2}(\boldsymbol{L 6 2})\right]$ (figure $53 \mathrm{~h}$ )

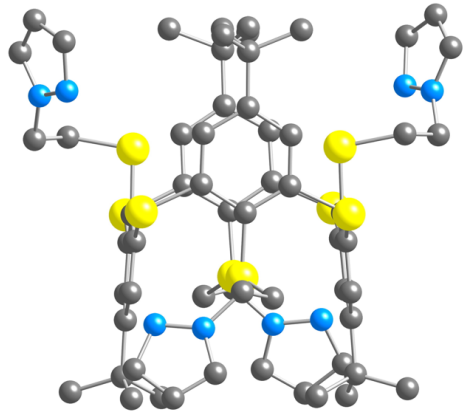

L60

a

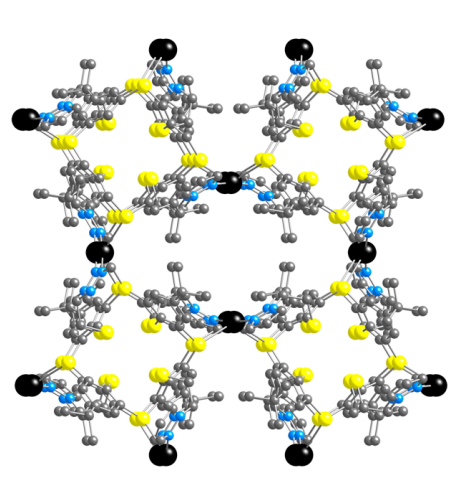

d

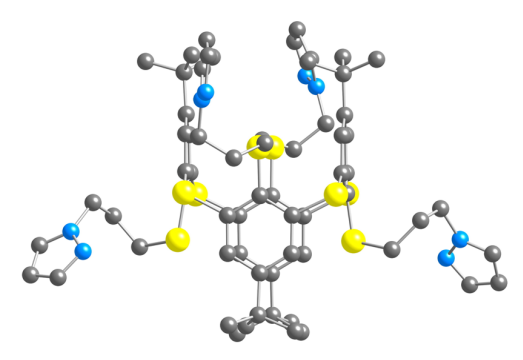

$L 61$

b

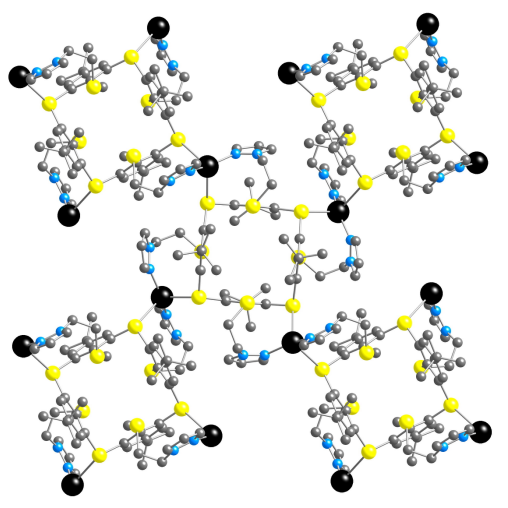

e

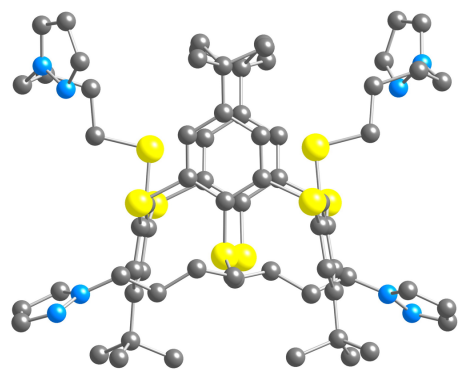

$L 62$

c

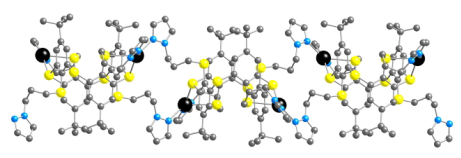

f 


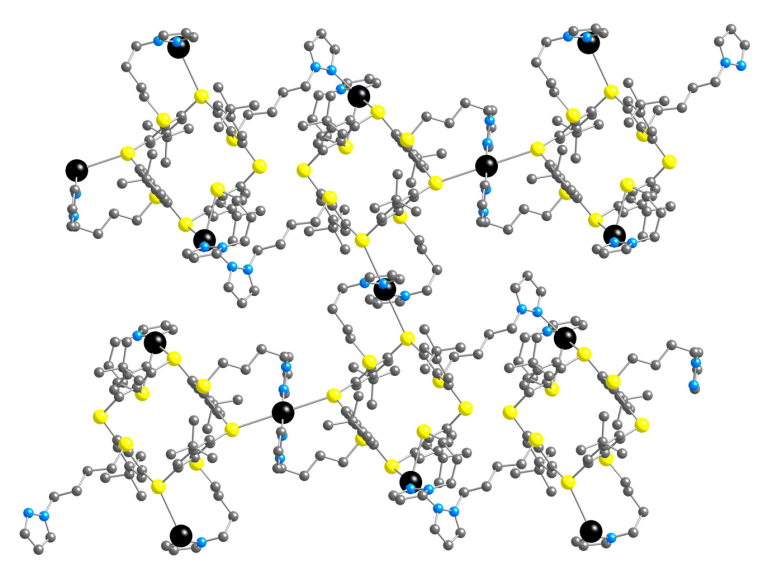

g

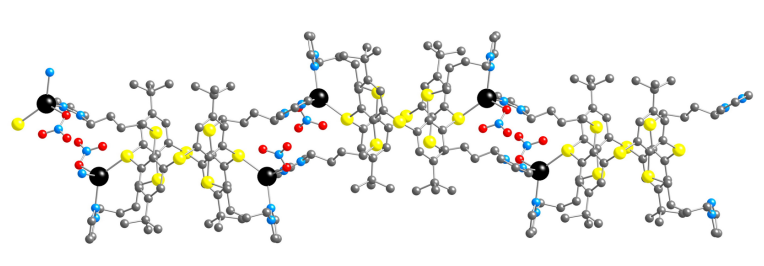

h

Figure 53: A portion of the X-ray structure showing the pyridyl appended tetramercaptotetrathiacalix[4]arene

L60-L62 (a-c) in 1,3-Alternate conformation, together with their corresponding Coordination Polymers when combined with silver salts : a diamond-like $3 \mathrm{D}$ Coordination Polymer of formula $\left[(\mathrm{AgX})_{2}(\boldsymbol{L 6 0})\right]\left(\mathrm{H}_{2} \mathrm{O}\right)_{3}\left(\mathrm{X}=\mathrm{SbF}_{6}\right.$,

$\mathrm{AsF}_{6}$ and $\left.\mathrm{PF}_{6}\right)(\mathrm{d})$, a 2D system of formula $\left[\left(\mathrm{AgBF}_{4}\right)_{2}(\boldsymbol{L 6 0})\right]\left(\mathrm{H}_{2} \mathrm{O}\right)_{0}$. (e), a 1D network of formula $\left[\left(\mathrm{AgSbF}_{6}\right)_{2}(\boldsymbol{L 6 1})\right]\left(\mathrm{CHCl}_{3}\right)_{2}(\mathrm{f})$, a $2 \mathrm{D}$ system of formula $\left[\left(\mathrm{AgSbF}_{6}\right)_{2}(\boldsymbol{L 6 2})\right]\left(\mathrm{CHCl}_{3}\right)_{35}\left(\mathrm{H}_{2} \mathrm{O}\right)(\mathrm{g})$ and a $1 \mathrm{D}$ network of formula $\left[\left(\mathrm{AgSbF}_{6}\right)_{2}(\boldsymbol{L 6 2})\right]\left(\mathrm{CHCl}_{3}\right)_{2}(\mathrm{~h})$. Black spheres represent $\mathrm{Ag}$ atoms. $\mathrm{H}$ atoms, solvent molecules and anions are not presented for sake of clarity. Adapted from Ref. [96]

This extensive, but non-exhaustive study showed us the wide variety of Coordination Polymers that can be obtained from the calixarene platform that may be modified in order to obtain Coordination Polymers of different dimensionalities, when assembled with different types of metals.

Several properties arise from the use of these macrocyclic ligands together with the judicious choice of the metals, leading to interesting architectures and they will be presented below.

\section{PROPERTIES}

The first property, related to the structural aspects of organization of the calixarene based building blocks in the solid-state, through the formation of channels and pores that may host guest molecules is porosity. Catalysis will also be developed. Then, the collective properties, resulting from the organization of individual molecules presenting properties (optical or magnetic, or NLO) will also be briefly presented.

\subsection{Porosity}

The property that has been targeted and mostly encountered in this type of Coordination Polymers based on calixarene, is related on the sorption/desorption abilities of such systems, essentially motivated by the previous work performed on isolated macrocyclic calixarene derivatives.

Pioneering work performed by Atwood et al. on systems containing calix[n]arene derivatives revealed that calixarene non porous supramolecular structure are able to absorb $\mathrm{N}_{2}$, $\mathrm{O}_{2}, \mathrm{CO}, \mathrm{CO}_{2}$, and $\mathrm{CH}_{4}$ with some degree of selectivity [101]. More recently, studies were extended to molecules like acetylene together with a number of nitrogen oxides [102]. DFT 
calculations by Venkataramanan et al. suggested that lithium functionalised p-tertbutylcalix[4] arene $(\mathrm{OH})_{4}$ would possess significantly enhanced binding energy and would be capable of $c a .10 \mathrm{wt} \% \mathrm{H}_{2}$ uptake [103]. Another example based on para-octanoylcalix[4]arene, was reported with adsorption isotherms measured for linear alkanes (C1-C4), ethylene, oxygen and nitrogen, at pressures of up to 4 bar and ambient temperature [104].

These isolated calixarene based compounds present promising potential concerning their application for gas storage for example.

Concerning the gas uptake activity of calixarene based Coordination Polymers, there are reported here. All the compounds $(13 \mathrm{CP})$ were preliminary activated and, for most of them, the remaining of the structure has been checked by XRPD.

The sorption properties of the activated reported Coordination Polymers are reported in Table 1 together, when possible, with values of BET surface areas.

For all the compounds, when possible, the measurements reveal a pseudo-type I behaviour with permanent micro-porosity. But for all the compounds, the surface area is low compared to the ones reported for performing MOFs.

The interest of the Coordination Polymers derived from calixarene derivatives is based on their abilities to separates different gases, or to adsorb different gases without loss of crystallinity or with a regeneration of the crystallinity, as shown by $\left[\mathrm{K}_{4}(\boldsymbol{L} 7)\right](\mathrm{MeOH})_{14}\left(\mathrm{H}_{2} \mathrm{O}\right)_{2}$ (figure 7 b) [21]. For example, simulations and measurements performed on $\left[\mathrm{Cd}_{2}(\boldsymbol{L 1 3})_{2}(\mathrm{DMF})_{2}\right](\mathrm{DMF})_{3}$ showed that it exhibits a high selectivity towards $\mathrm{H}_{2}$ in $\mathrm{H}_{2} / \mathrm{CH}_{4}$ mixtures [33]. An analogous behaviour was observed for $\left[\mathrm{Nd}_{6}(\mathrm{OH})_{{ }}(\boldsymbol{L 1 8})_{2}\left(\mathrm{H}_{2} \mathrm{O}\right)\right]$ compared to $\mathrm{CH}_{4}$ and $\mathrm{CO}_{2}$ adsorptions [44]. [ $\left.\mathrm{Mn}_{16}(\boldsymbol{L} 46)_{12}\left(\left(\mathrm{CH}_{3}\right)_{2} \mathrm{NH}_{2}\right)_{16}\right]$ and $\left[\mathrm{K}_{16} \mathbf{M n}_{10}(\boldsymbol{L} 46)_{12}\left(\left(\mathrm{CH}_{3}\right)_{2} \mathrm{NH}_{2}\right)_{16}\right]$ present both high $\mathrm{CO}_{2}$ uptake performance [90].

\begin{tabular}{|c|c|c|c|c|c|}
\hline Compound & Structure & $\begin{array}{c}\text { BET surface } \\
\text { meg.-1 }^{-1}\end{array}$ & $\begin{array}{c}\text { Type of } \\
\text { isotherm }\end{array}$ & $\begin{array}{c}\text { Adsorption } \\
\text { of other } \\
\text { gas/solvents }\end{array}$ & Reference \\
\hline$\left\{[\mathrm{Co} \cdot \mathrm{Cl}(\boldsymbol{L} \mathbf{1})]\left[\mathrm{Co}, \mathrm{Cl}(\boldsymbol{L} \mathbf{1})\left(\mathrm{CH}_{3} \mathrm{OH}\right)_{2}\left(\mathrm{H}_{2} \mathrm{O}_{2}\right)_{2}\right]\right\}$ & $\begin{array}{c}1 \mathrm{D} \\
\text { zigzag chains } \\
\text { Figure } 9 \mathrm{~b} \\
\end{array}$ & $\approx 220$ & Type I & - & [23] \\
\hline$\left\{\left[\mathrm{M}_{4} \mathrm{Cl}(\boldsymbol{L 1})(\right.\right.$ ina $\left.\left.)\right]\left(\mathrm{M}^{\mathrm{r}} \mathrm{Cl}_{2}\right)\right\} \mathrm{M}^{\mathrm{n}}=\mathrm{Fe}$ or $\mathrm{Co}$ & $\begin{array}{c}2 \mathrm{D} \\
\text { figure } 9 \mathrm{c}\end{array}$ & $\begin{array}{l}360(\mathrm{M}=\mathrm{Fe}) \\
251(\mathrm{M}=\mathrm{Co})\end{array}$ & Type I & $\mathrm{H}_{2}, \mathrm{CO}_{2}$ & [24] \\
\hline$\left[\mathrm{HCo}_{4} \mathrm{Cl}(\boldsymbol{L 1}](\mathrm{DCPB})_{2}\right]$ & $\begin{array}{c}1 \mathrm{D} \\
\text { zigzag chains } \\
\text { figure } 9 \mathrm{f}\end{array}$ & 348 & Type I & - & [27] \\
\hline$\left[\mathrm{K}_{.}(\boldsymbol{L} 7)\right](\mathrm{MeOH})_{1:}\left(\mathrm{H}_{2} \mathrm{O}\right)_{2}$ (figure 7 b) & $\begin{array}{c}1 \mathrm{D} \\
\text { (figure } 7 \mathrm{~b} \text { ) }\end{array}$ & not determined & & $\mathrm{MeOH}, \mathrm{C}_{6} \mathrm{H}_{6}$ & [21] \\
\hline$\left\{\left[\mathrm{Co}_{2}\left(\mathrm{H}_{2} \mathrm{O}\right)(\boldsymbol{L B})(\mathrm{HCOO})_{]_{2}}(\mathrm{bpy})\right\}\right.$ & $\begin{array}{c}1 \mathrm{D} \\
\text { figure } 9 \mathrm{~d}\end{array}$ & 256 & Type I & - & [25] \\
\hline$\left[\mathrm{Cu}_{2}(\boldsymbol{L 1 3})_{2}(\mathrm{DMF})_{2}\right]$ & $\begin{array}{c}2 \mathrm{D} \\
\text { figure } 13 \mathrm{c}\end{array}$ & 190 & Type I & $\mathrm{H}_{2}, \mathrm{CH}_{4}$ & [33] \\
\hline$\left[\mathrm{Cd}_{2}(\boldsymbol{L 1 3})_{2}(\mathrm{DMF})_{2}\right](\mathrm{DMF})_{3}$ & $\begin{array}{c}3 \mathrm{D} \\
\text { figure } 12 \mathrm{~d}\end{array}$ & 410 & Type I & $\mathrm{H}_{2}, \mathrm{CH}_{4}$ & [33] \\
\hline$\left[\mathrm{Co}_{s}(\boldsymbol{L} \mathbf{L 1 3})_{s_{i}}(\mathrm{OH})_{2}\left(\mathrm{H}_{2} \mathrm{O}\right)_{4}\right](\mathrm{DMF})_{s}$ & $\begin{array}{c}2 \mathrm{D} \\
\text { figure } 13 \mathrm{~b}\end{array}$ & 441 & Type I & $\mathrm{H}_{2}, \mathrm{CH}_{4}$ & [33] \\
\hline$\left[\mathrm{Nd}_{b}(\mathrm{OH})_{s}(\boldsymbol{L 1 8})_{2}\left(\mathrm{H}_{2} \mathrm{O}\right)_{r}\right]$ & $\begin{array}{c}2 \mathrm{D} \\
\text { figure } 16 \mathrm{c}\end{array}$ & 14 & Type I & $\mathrm{H}_{2}, \mathrm{CH}_{4}, \mathrm{CO}_{2}$ & [44] \\
\hline$\left.\left[\mathrm{Na}_{2} \mathrm{~K}_{2}(\boldsymbol{L} 19)\right]\left(\mathrm{H}_{2} \mathrm{O}\right)_{H_{1}}\right]$ & $\begin{array}{c}3 \mathrm{D} \\
\text { figure } 22 \mathrm{e}\end{array}$ & not determined & & $\mathrm{CO}_{2}$ & [55] \\
\hline
\end{tabular}




\begin{tabular}{|c|c|c|c|c|}
\hline$\left[\mathrm{Pb}_{2}(\boldsymbol{L 3 9})\right] \cdot 2 \mathrm{DMF}$ & $\begin{array}{c}\mathrm{DD} \\
\text { figure } 39 \mathrm{e}\end{array}$ & Very low & $\mathrm{CO}_{2}$ & [81] \\
\hline$\left[\mathrm{Mn}_{11}(\boldsymbol{L 4 6})_{12}\left(\left(\mathrm{CH}_{3}\right)_{2} \mathrm{NH}_{2}\right)_{16}\right] . \mathrm{S}$ & $\begin{array}{c}3 \mathrm{D} \\
\text { figure } 44 \mathrm{e}\end{array}$ & 236 & $\mathrm{CO}_{2}$ & [90] \\
\hline$\left[\mathrm{K}_{16} \mathrm{Mn}_{16}(\boldsymbol{L 4 6})_{12}\left(\left(\mathrm{CH}_{3}\right)_{2} \mathrm{NH}_{2}\right)_{16}\right] . \mathrm{S}$ & $\begin{array}{c}3 \mathrm{D} \\
\text { figure } 44 \mathrm{f}\end{array}$ & 184 & $\mathrm{CO}_{2}$ & [90] \\
\hline
\end{tabular}

Table 1: Adsorption properties of some reported calixarene based Coordination Polymers.

\subsection{Magnetic properties}

Contrary to other Coordination Polymers, there are not so many examples of magnetic calixarene based Coordination Polymers. This is essentially due to the fact that the metallic nodes (M) in the calixarene based Coordination Polymers are often located too far for any magnetic coupling. The only way to overcome this is to force the presence of clusters within the formed networks, with short M-M distances. Among the reported Coordination Polymers, there are two types of metallic clusters that can display magnetic properties: Copper(II) and Cobalt(II) containing species. In most of the cases the modelling of the interaction has not been performed, only the nature of the interaction is discussed.

One example of that type is provided by the compound including a paddle wheel Copper(II) dimeric unit in $\left[\mathrm{Cu}_{2}(\mu-\mathrm{OAc})_{4}(\mu-\mathbf{L 3 1})\right] \mathrm{S}$ (figure $\left.35 \mathrm{~b}\right)$ [75], this paddle-wheel feature is very well known in the field of molecular magnetism [105]. For this compound, ESR data evidenced strongly antiferromagnetically coupled $\mathrm{Cu}$ (II) centres with a strong, as expected, coupling constants of $\mathrm{J}$ of $c a .-346 \mathrm{~cm}^{-1}$. $\left[\mathrm{Cu}_{2} \mathrm{Cl}_{2}(\mathbf{L 2})\right]\left(\mathrm{CH}_{3} \mathrm{OH}\right)\left(\mathrm{CHCl}_{3}\right)_{\text {s }}$ (figure $4 \mathrm{~d}$ ) also displays a dominant strong antiferromagnetic coupling between $\mathrm{Cu}(\mathrm{II})$ centres [16].

Another example provided from the network of formula $\left[\mathrm{Cu}\left(\mathrm{H}_{2} \mathrm{O}\right)_{6}\right]\left[\mathrm{Cu}_{2}(\boldsymbol{L 1 8})(\mu-2,2\right.$ 'bpno) $\left.\left(\mathrm{H}_{2} \mathrm{O}\right)_{3}\right]\left(\mathrm{H}_{2} \mathrm{O}\right)_{10}$ (figure 22 e) presenting relatively short $\mathrm{Cu}(\mathrm{II})-\mathrm{Cu}(\mathrm{II})$ distances [56], where the magnetic data also indicate the presence of weak ferromagnetic coupling between $\mathrm{Cu}(\mathrm{II})$ ions.

Concerning Cobalt(II) based Coordination Polymer, $\left\{\left[\mathrm{Co}_{3}\left(\mathrm{H}_{2} \mathrm{O}\right)(\boldsymbol{L 8})(\mathrm{HCOO})_{2}\right]_{2}(\right.$ bpy $\left.)\right\}$ (figure $9 \mathrm{~d}$ ) [25] and $\left[\mathrm{Co}_{s}(\boldsymbol{L 2})_{2}(\mathrm{camph})_{3} \mu_{-}-\mathrm{Cl}_{2}\right]$ (figure 9 e) [26], both present antiferromagnetic coupling between Cobalt (II) cations.

\subsection{Optical properties}

Due to its non-centrosymmetric character, the bimetallic compound $\left[\mathrm{K}_{3} \mathrm{Co}_{2}(\boldsymbol{L 3 7})_{3}(\mathrm{EtOH})_{6}\right] \mathrm{Cl}$ (figure $37 \mathrm{~b}$ ) is the first $3 \mathrm{D}$ calixarene based Coordination Polymer presenting second-order NLO properties [78]. Its second harmonic generation (SHG) response is equivalent to the one of urea. In contrast, a powder SHG response of only about $10 \%$ of that for urea was found for the naked calixarene ligands $\boldsymbol{L} 37$ (figure 35 a). This evidently indicates an enhancement of the SHG efficiency into the Coordination Polymers.

The NLO properties of $\left.\left[\mathrm{Mn}_{16}(\boldsymbol{L 4 6})_{12}\left(\mathrm{CH}_{3}\right)_{2} \mathrm{NH}_{2}\right)_{16}\right] . S$ (figure 44 e) and $\left[\mathrm{K}_{16} \mathrm{Mn}_{10}(\boldsymbol{L 4 6 6})_{12}\left(\left(\mathrm{CH}_{3}\right)_{2} \mathrm{NH}_{2}\right)_{16}\right] . S$ (figure 44 f) [90], have also been mentioned, with SHG response being larger than the one of urea. 


\subsection{Luminescent properties in the solid state}

When appropriated metals were incorporated in the Coordination Polymer, luminescent properties of the CA and TCA Coordination Polymers were analysed, only in the solid state. This concerns also the luminescent properties of the isolated ligands in the solid state. For example by analysing, in the solid state, the luminescence of simple ligand TCA (L1, cone conformation, figure 3 a) and its tetraphenyl appended analogue ( $\mathbf{L}$, cone conformation, figure $3 \mathrm{c}$ ), it was found that both exhibit an emission upon excitation at 350 $\mathrm{nm}$ with maxima at 367 and $383 \mathrm{~nm}$, respectively, which might be attributed to the intraligand $\pi^{*}$ to $\pi$ transition of the calixarene ligands [16]. The luminescent properties of other ligands are usually systematically reported, when analysing the one of the corresponding molecular networks.

\section{Copper(I) Coordination Polymers}

Several examples are arising from Copper(I) Coordination Polymers.

The corresponding Coordination Polymers containing $\mathrm{d}^{10}$ metals like $\mathrm{Cu}(\mathrm{I})$ atoms, with the following formula $\left[\mathrm{Cu}_{2} \mathrm{Cl}_{2}(\boldsymbol{L 1})\right]\left(\mathrm{CH}_{3} \mathrm{OH}\right)$ (figure 4 b) and $\left[\mathrm{Cu}_{2} \mathrm{Cl}_{2}(\boldsymbol{L 2})\right]\left(\mathrm{CH}_{3} \mathrm{OH}\right)\left(\mathrm{CHCl}_{3}\right)_{0.5}$ (figure $4 \mathrm{~d}$ ) were also analysed and exhibit blue emission peaks at approximately 410 and 470 $\mathrm{nm}$ for the first compound and 403 and $467 \mathrm{~nm}$ for the second one upon excitation at $230 \mathrm{~nm}$ [16]. The emission peaks at 410 and $403 \mathrm{~nm}$ should be assigned to the emission of the corresponding ligands. The red shifted peaks at 470 and $467 \mathrm{~nm}$ are in accordance with the photo-luminescence properties of cuprous halide clusters, and the emissions may be attributed to a mixture of chlorine-to-copper charge transfer and $\mathrm{d}-\mathrm{s}$ transitions due to $\mathrm{Cu} \cdots \mathrm{Cu}$ interactions within the $\mathrm{Cu}_{2}$ cluster.

Another contribution of $\mathrm{Cu}(\mathrm{I}) \mathrm{d}^{10}$ metals based Coordination Polymers arises from the 3D Coordination Polymer $\left[\mathrm{Cu}_{4} \mathrm{I}_{4}(\mathbf{L 2 9})\right]$ (cubane-type $\mathrm{Cu}_{4} \mathrm{I}_{4}$, figure $32 \mathrm{~d}$ ) exhibiting a brightorange-yellow emission $\left(\lambda_{\mathrm{em}}=531 \mathrm{~nm}\right)$ in the solid state arising from the cluster centred excited state with mixed halide-to-metal charge- transfer character [68]. The parent 3D Coordination Polymer of formula $\left[\left(\mathrm{Cu}_{3} \mathrm{I}_{3}\right)(\mathbf{L 2 9})\left(\mathrm{CH}_{3} \mathrm{CN}\right)\right]\left(\mathrm{CH}_{2} \mathrm{Cl}_{2}\right)\left(\mathrm{H}_{2} \mathrm{O}\right)_{2}$ (figure $32 \mathrm{e}$ ), when desolvated, presents a bright photoluminescence dominated by emission at $420 \mathrm{~nm}\left(\lambda_{\mathrm{ex}}=320\right.$ $\mathrm{nm}$ ) undoubtedly due to the generation of a cluster-centred excited-state with mixed halide-tometal charge transfer character, conferring to this compound the property of solvatophotoluminescence displaying a "off-on" behaviour [69]. Compound $\left[\left(\mathrm{Cu}_{2} \mathrm{I}_{2}\right)(\boldsymbol{L 2 9})_{2}\left(\mathrm{Cu}_{4} \mathrm{I}_{4}\right)\right]\left(\mathrm{CH}_{2} \mathrm{Cl}_{2}\right)\left(\mathrm{CH}_{3} \mathrm{CN}\right)$ (figure $32 \mathrm{f}$ ) exhibits an orange emission $\left(\lambda_{\mathrm{em}}=531 \mathrm{~nm}\right.$, $\left.\lambda_{\mathrm{cx}}=320 \mathrm{~nm}\right)$ in the solid state arising from the $\mathrm{Cu}_{4} \mathrm{I}_{4}$ cubane unit [69].

The 1D compound $\left[\left(\mathrm{Cu}_{4} \mathrm{I}_{4}\right)(\mathbf{L 3 0})\left(\mathrm{CH}_{3} \mathrm{CN}\right)_{2}\right]$ (figure $32 \mathrm{~h}$ ) also exhibits reversible photoluminescence switching behaviour reflecting the addition/removal of coordinated $\mathrm{CH}_{3} \mathrm{CN}$ solvent molecules (bright yellow emission $\left(\lambda_{\mathrm{em}}=567 \mathrm{~nm}, \lambda_{\mathrm{ex}}=365 \mathrm{~nm}\right)$ whereas the solvent free compound displays a bright red emission $\left(\lambda_{\mathrm{em}}=600 \mathrm{~nm}, \lambda_{\mathrm{ex}}=365 \mathrm{~nm}\right)$ [70].

The luminescent properties of the $1 \mathrm{D}$ compound of formula $\left[\mathrm{Cu}\left(\mathrm{H}_{2} \mathrm{O}\right)_{6}\right]\left[\mathrm{Cu}_{2}(\boldsymbol{L 1 9})(\mu\right.$ 2,2'-bpno) $\left.\left(\mathrm{H}_{2} \mathrm{O}\right)_{3}\right]\left(\mathrm{H}_{2} \mathrm{O}\right)_{10}(2,2$ '-bpno = 2,2' -bipyridine-1,10 dioxide) (figure $22 \mathrm{f}$ ) have also been reported and evidenced an emission at $\lambda_{\mathrm{cm}}=446 \mathrm{~nm}\left(\lambda_{\mathrm{cx}}=366 \mathrm{~nm}\right)$, which may be attributed to the intraligand $\pi^{*}-\pi$ transition [56]. 


\section{Zinc(II) Coordination Polymers}

Tetraacetate $p$-H-calix[4]arene ( $\boldsymbol{L 4 1}$ figure 40 a) and tetraacetate $p$-tertbutylcalix[4]arene ( $\boldsymbol{L 4 2}$ figure $40 \mathrm{~b}$ ) exhibit luminescence in the solid state $\left(\lambda_{\mathrm{cm}}=370 \mathrm{~nm}, \boldsymbol{\lambda}_{\mathrm{c}}=\right.$ $314 \mathrm{~nm}$ for $\boldsymbol{L 4 1}$ and $\boldsymbol{\lambda}_{\mathrm{sm}}=489 \mathrm{~nm}, \boldsymbol{\lambda}_{\mathrm{ax}}=369 \mathrm{~nm}$ for $\boldsymbol{L 4 2}$ ) corresponding to $\pi^{*-} \pi$ or $\pi^{*}-\mathrm{n}$ transitions of the calixarene ligands [83]. The emission of the corresponding Coordination Polymers is based on the emission of the free ligands. 2D compounds of formula $\left[\mathrm{Zn}_{6} \mathrm{Na}_{6}(\boldsymbol{L 4 1})_{4}(\mathrm{OH})_{2}(\mathrm{imi}-4)\left(\mathrm{H}_{2} \mathrm{O}\right)_{4}\right]\left(\mathrm{H}_{2} \mathrm{O}\right)_{s}$ (figure 40 c) shows a main emission peak centred at $433 \mathrm{~nm}$ with a shoulder at $374 \mathrm{~nm}$ upon excitation $\lambda_{\mathrm{ac}}=320 \mathrm{~nm}$. On the basis of the emission peaks, the N-donor ligands (imi-4) and O-donor anions (L39) may show contributions to the broad fluorescent emissions simultaneously [83].

\section{Cadmium(II) Coordination Polymer}

The 3D Coordination Polymer of formula $\left[\mathrm{Cd}_{4}(\boldsymbol{L 3 9})_{2}(\mathrm{DMF})_{6}\right]$ together with $\boldsymbol{L} \mathbf{3 9}$ exhibit blue emission in the solid state at room temperature [82]. For the ligand, the maximum of emission, due to $\pi^{*}-\pi$ transition, is at $\lambda_{\mathrm{sm}}=430 \mathrm{~nm}$ whereas for $\left[\mathrm{Cd}_{i}(\boldsymbol{L 3 9})_{2}(\mathrm{DMF})_{6}\right]$, it is observed at $\lambda_{\mathrm{sm}}=446 \mathrm{~nm}[82]$.

\section{Lead(II) Coordination Polymer}

The 3D Coordination Polymers of formula $\left[\mathrm{Pb}_{2}(\boldsymbol{L 3 9})\right](\mathrm{DMF})_{2}$ presenting a ths topology (figure 39 e) together with $\boldsymbol{L} \mathbf{3 9}$ exhibit blue emission in the solid state at room temperature. For the ligand the maximum of emission, due to $\pi^{*}-\pi$ transition, is at $\lambda_{\mathrm{cm}}=426 \mathrm{~nm}$ whereas for $\left[\mathrm{Pb}_{2}(\boldsymbol{L 3 9})\right](\mathrm{DMF})_{2}$, it is observed at $\lambda_{\mathrm{m}}=473$ and $518 \mathrm{~nm}$ [81]. For the molecular network, compared to $\boldsymbol{L 3 9}$, it exhibits increased intensities and red shifts, attributed to the increased molecular rigidity of the network.

\subsection{Heterogeneous Catalysis}

Coordination Polymers are often used as platform for catalytic studies. Few examples are provided with calixarene based Coordination Polymers.

For example, the activity of the 1D bimetallic system of formula $\left[\left(\mathrm{VO}_{2}\right)_{2}\left(\boldsymbol{L 1 1 H}_{2}\right)^{-}\right.$ $\left.\left(\mathrm{Li}(\mathrm{MeCN})_{2}\right)_{2}\right] \cdot 2 \mathrm{MeCN}$ (figure $11 \mathrm{~d}$ ), in the presence of a variety of co-catalysts and under various conditions has been investigated: the compound acts as a as pre-catalysts for ethylene polymerization [30].

Another family of $\mathrm{Ln}$ based compounds, $\left[\mathrm{Ln}_{6}(\mathrm{OH})_{,}(\mathrm{L} 17)_{2}\left(\mathrm{H}_{2} \mathrm{O}\right)\right](\mathrm{Ln}=\mathrm{La}$, $\mathrm{Pr}$ or $\mathrm{Nd})$ (figure $16 \mathrm{c}$ ) presents catalytic properties for the oxidation of methyl phenyl sulphide, whereas the catalysts can be reused at least in three consecutive cycle with a high activity, without any alteration of the structure [44].

Finally, the photocatalytic activity of 2D Coordination Polymer formation of formula $\left[\mathrm{Ag}_{4}(\boldsymbol{L 3 6})\left(\mathrm{NO}_{3}\right)_{4}\right]$ (figure $36 \mathrm{~b}$ ) was investigated. The compound is the first example of a Coordination Polymer that can be used for both the selective detection and efficient degradation of nitrobenzene derivatives, under UV light [77]. 


\section{CONCLUSION AND OUTLOOKS}

As demonstrated within this non-exhaustive review, a wide variety of Coordination Polymers can be obtained from the macrocyclic calixarene platform that has been widely modified for this purpose. Table 2 summarises, the nature (dimensionality, ligand and used metals) of the Coordination Polymers based on the macrocyclic calixarene backbone that have been reported in the literature. One can see that several metals have been combined with calixarene based ligands: alkali and earth-alkali cations, transition metals (1" $2^{\text {nd }}$ and $3^{\text {rd }}$ rows) and rare earth metals. The coordination abilities of the metals, together with the affinities of the metals towards the available donor atoms ( $\mathrm{O}, \mathrm{S}$ and $\mathrm{N}$ essentially) is crucial for the recognition and the coordination pattern between ligands and metals. The predictability of the coordination pattern [106] appears rather restricted with this types of macrocyclic ligands, that offers a high flexibility: too many factors influence the dimensionality of the formed Coordination Polymers: (i) number and location of coordinating atoms in the calixarene based building blocks, (ii) number and location of the coordinating groups (upper and lower rim) (iii) conformation of the used calixarene based building block (iv) nature (geometry and affinities) of the used metals and (v) use of ancillary coordinating ligands.

Table 2: Summary of the different reported calixarene and thiacalixarene based Coordination Polymers.

\begin{tabular}{|c|c|c|c|c|c|c|}
\hline & $L$ & $\begin{array}{c}\text { Conformation } \\
\text { calix }\end{array}$ & $\begin{array}{l}\text { Coordinating } \\
\text { groups/atoms }\end{array}$ & Metals & Dimensionality & Refs \\
\hline \multirow{2}{*}{ 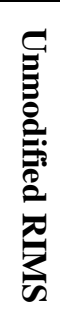 } & $L 1-L 6$ & cone & S & $\begin{array}{c}\mathrm{Cu}(\mathrm{I}), \operatorname{Ag}(\mathrm{I}), \mathrm{K}(\mathrm{I}), \\
\mathrm{Rb}(\mathrm{I})\end{array}$ & $2 \mathrm{D}, 1 \mathrm{D}$ & [16-20] \\
\hline & $\begin{array}{c}\mathbf{L 1} \text { or } \boldsymbol{L 8}+\text { ancillary } \\
\text { ligands }\end{array}$ & cone & $\mathrm{S} / \mathrm{O}+\mathrm{N}$ & $\mathrm{Co}(\mathrm{II}), \mathrm{Fe}(\mathrm{II})$ & $2 \mathrm{D}, 1 \mathrm{D}$ & [22-27] \\
\hline \multirow{11}{*}{ 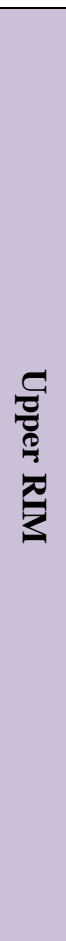 } & L9 & cone & Ag-pi & $\operatorname{Ag}(\mathrm{I})$, & $2 \mathrm{D}$ & {$[28]$} \\
\hline & $\mathbf{L 1 2}+$ ancillary ligands & cone & Carboxylate $+\mathrm{N}$ & $\begin{array}{l}\mathrm{Co}(\mathrm{II})+ \\
\mathrm{N} \text { ligand }\end{array}$ & $1 \mathrm{D}$ & {$[31]$} \\
\hline & $L 13$ & cone & Carboxylate & $\begin{array}{l}\mathrm{Co}(\mathrm{II}), \mathrm{Cd}(\mathrm{II}), \\
\mathrm{Cu}(\mathrm{II}), \mathrm{Zn}(\mathrm{II})\end{array}$ & $2 \mathrm{D}, 3 \mathrm{D}$ & [33] \\
\hline & L14 + ancillary ligands & cone & Carboxylate $+\mathrm{N}$ & $\mathrm{Cd}(\mathrm{II})+\mathrm{N}$ ligand & 1D & [34] \\
\hline & $L 15$ & 1,3-Alternate & Carboxylate & $\mathrm{Rb}(\mathrm{I})$ & 1D & [35] \\
\hline & $L 16$ & cone & Carboxylate & $\begin{array}{c}\mathrm{Eu}(\mathrm{III}), \mathrm{Nd}(\mathrm{III}) \\
\mathrm{Yb}(\mathrm{III}), \mathrm{Y}(\mathrm{III}) \\
\mathrm{Cd}(\mathrm{II})\end{array}$ & $2 \mathrm{D}, 3 \mathrm{D}$ & [36-37] \\
\hline & $L 17$ & 1,3-Alternate & Cyano & $\overline{A g}(\mathrm{I})$ & 1D & {$[38]$} \\
\hline & $L 18$ & cone & O (sulfonato) & $\begin{array}{l}\mathrm{Sc}(\mathrm{III}), \mathrm{Ce}(\mathrm{III}), \\
\operatorname{Pr}(\mathrm{III}), \mathrm{Nd}(\mathrm{III}), \\
\mathrm{Yb}(\mathrm{III}), \mathrm{Sm}(\mathrm{III})\end{array}$ & $2 \mathrm{D}, 3 \mathrm{D}$ & [39-46] \\
\hline & $\mathbf{L 1 8}+$ ancillary ligands & cone & $\mathrm{O}$ (sulfonato) $+\mathrm{N}$ & $\begin{array}{c}\mathrm{Ag}(\mathrm{I}), \mathrm{Cu}(\mathrm{II}) \\
\mathrm{Nd}(\mathrm{III}), \mathrm{Eu}(\mathrm{III})\end{array}$ & $1 \mathrm{D}, 2 \mathrm{D}, 3 \mathrm{D}$ & {$[47-50]$} \\
\hline & $L 19$ & cone & $\begin{array}{c}\text { O (sulfonato) } \\
\mathrm{S}\end{array}$ & $\begin{array}{c}\mathrm{Co}(\mathrm{II}), \mathrm{Cu}(\mathrm{II})+\mathrm{N} \\
\text { ligand } \\
\mathrm{Na}(\mathrm{I}), \mathrm{K}(\mathrm{I})\end{array}$ & $1 \mathrm{D}, 2 \mathrm{D}, 3 \mathrm{D}$ & {$[51-55]$} \\
\hline & $L 20$ & cone & $\mathrm{O}$ (sulfonato) & $\mathrm{Eu}(\mathrm{III})+\mathrm{Na}(\mathrm{I})$ & $1 \mathrm{D}, 2 \mathrm{D}$ & [57-59] \\
\hline
\end{tabular}




\begin{tabular}{|c|c|c|c|c|c|c|}
\hline & & & & $\begin{array}{l}\mathrm{Ln}(\mathrm{III})+\mathrm{Na}(\mathrm{I}) \\
\mathrm{Gd}(\mathrm{III})+\mathrm{Na}(\mathrm{I})\end{array}$ & & \\
\hline & L21 + ancillary ligands & double paco & $\mathrm{O}$ (sulfonato)+N & $\mathrm{Eu}(\mathrm{III})$ & 1D & [60] \\
\hline & $\mathbf{L 2 2}+$ ancillary ligands & $1,2,3-\mathrm{A}$ & $\mathrm{O}$ (sulfonato)+N & $\mathrm{Co}(\mathrm{II}), \mathrm{Cu}(\mathrm{II}), \mathrm{Zn}(\mathrm{II})$ & $2 \mathrm{D}, 1 \mathrm{D}$ & [61] \\
\hline & $L 23$ & $1,2,3-\mathrm{A}$ & $\mathrm{O}$ (sulfonato) & $\mathrm{La}(\mathrm{III}), \mathrm{Ce}(\mathrm{III})$ & $1 \mathrm{D}$ & [62] \\
\hline & $L 24$ & $\begin{array}{c}\text { Pinched } \\
\text { double cone }\end{array}$ & $\mathrm{O}$ (sulfonato) & $\mathrm{Ba}(\mathrm{II})$ & $2 \mathrm{D}$ & [63] \\
\hline & $L 25$ & Pleated loop & $\mathrm{O}$ (sulfonato) & $\mathrm{Eu}(\mathrm{III})$ & 3D & [64] \\
\hline & $L 26$ & cone & $\mathrm{O}$ (phosphonato) & $\begin{array}{l}\mathrm{Ca}(\mathrm{II}), \mathrm{La}(\mathrm{III}), \\
\operatorname{Pr}(\mathrm{III}), \mathrm{Nd}(\mathrm{III})\end{array}$ & $2 \mathrm{D}, 3 \mathrm{D}$ & [65] \\
\hline & $L 27$ & cone & $\mathrm{O}$ (phosphonato) & $\mathrm{Ca}(\mathrm{II})$ & $2 \mathrm{D}, 1 \mathrm{D}$ & [66] \\
\hline & $L 28$ & cone & $\begin{array}{c}\mathrm{O} \\
\text { (phosphineoxide) }\end{array}$ & $\mathrm{Ni}(\mathrm{II})$ & 1D & [67] \\
\hline \multirow{21}{*}{ 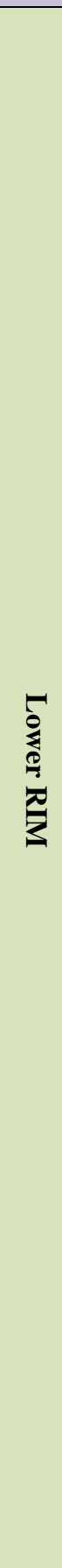 } & $L 29$ and $L 30$ & 1,3-Alternate & $\mathrm{S}, \mathrm{O}$ (thiacrown) & $\mathrm{Cu}(\mathrm{I}), \mathrm{Hg}(\mathrm{II})$ & $3 \mathrm{D}, 2 \mathrm{D}, 1 \mathrm{D}$ & {$[68-71]$} \\
\hline & $L 31$ and $L 32$ & 1,3-Alternate & $\mathrm{S}, \mathrm{O}$ (thiacrown) & $\mathrm{Cu}(\mathrm{I})+\mathrm{K}(\mathrm{I})$ & 1D & [72] \\
\hline & $L 33$ and $L 34$ & cone & $\mathrm{O}$ (quinone) & $\mathrm{Na}(\mathrm{I}), \mathrm{Pb}(\mathrm{II})$ & $1 \mathrm{D}, 3 \mathrm{D}$ & [73-74] \\
\hline & $L 35$ & cone & pyridyl & $\mathrm{Cu}(\mathrm{II})$ & 1D & {$[75-76]$} \\
\hline & $L 36$ & cone & pyridyl & $\operatorname{Ag}(\mathrm{I})$ & & [77] \\
\hline & $L 37$ & 1,3-Alternate & Carboxylate & $\mathrm{Co}(\mathrm{II})+\mathrm{K}(\mathrm{I})$ & $3 \mathrm{D}$ & [78] \\
\hline & $L 38$ & cone & Carboxylate & $\mathrm{Zn}(\mathrm{II})$ & $1 \mathrm{D}$ & [79] \\
\hline & $L 39$ and $L 40$ & 1,3-Alternate & Carboxylate & $\mathrm{Ag}(\mathrm{I}), \mathrm{Pb}(\mathrm{II}), \mathrm{Cd}(\mathrm{II})$ & 1D & [80-82] \\
\hline & $L 41$ and $L 42$ & cone & Carboxylate & $\begin{array}{c}\mathrm{Zn}(\mathrm{II})+\mathrm{Na}(\mathrm{I}) \\
\mathrm{Co}(\mathrm{II})+\mathrm{Na}(\mathrm{I}) \\
\mathrm{Cu}(\mathrm{II})+\mathrm{Na}(\mathrm{I}) \\
\mathrm{Ni}(\mathrm{II})+\mathrm{N} \text { ligand }\end{array}$ & $1 \mathrm{D}, 2 \mathrm{D}$ & [83-84] \\
\hline & $L 43$ & 1,3-Alternate & Cyano & $\mathrm{Ag}(\mathrm{I})$ & $1 \mathrm{D}$ & [85] \\
\hline & $L 44$ & 1,3-Alternate & $\begin{array}{c}\text { Cyano } \\
\text { S }\end{array}$ & $\operatorname{Ag}(\mathrm{I})$ & $3 \mathrm{D}$ & [86] \\
\hline & $L 45$ & 1,3-Alternate & Carboxylate & $\begin{array}{c}\mathrm{Ag}(\mathrm{I}) \\
\mathrm{Ni}(\mathrm{II}), \mathrm{Co}(\mathrm{II}), \mathrm{Zn}(\mathrm{II}) \\
+\mathrm{K}(\mathrm{I})\end{array}$ & $1 \mathrm{D}, 2 \mathrm{D}$ & {$[87-88]$} \\
\hline & $L 46$ & 1,3-Alternate & $\begin{array}{c}\text { Carboxylate } \\
\text { S }\end{array}$ & $\begin{array}{c}\mathrm{Co}(\mathrm{II})+\mathrm{Na}(\mathrm{I})+\mathrm{N} \\
\text { ligand } \\
\mathrm{Cd}(\mathrm{II})+\mathrm{N} \text { ligand } \\
\mathrm{Mn}(\mathrm{II})+\mathrm{K}(\mathrm{I})+\mathrm{N} \\
\text { ligand }\end{array}$ & $3 \mathrm{D}$ & [89-90] \\
\hline & $L 47-L 49$ & 1,3-Alternate & $\begin{array}{l}\text { Pyridyl } \\
\text { S }\end{array}$ & $\begin{array}{l}\mathrm{Ag}(\mathrm{I}) \\
\mathrm{Cd}(\mathrm{II}) \\
\mathrm{Fe}(\mathrm{II}) \\
\end{array}$ & $2 \mathrm{D}, 3 \mathrm{D}$ & [91-93] \\
\hline & $L 50-L 52$ & 1,3-Alternate & Pyridyl & $\mathrm{Hg}(\mathrm{II})$ & $1 \mathrm{D}, 2 \mathrm{D}$ & {$[93-95]$} \\
\hline & $L 53$ & 1,3-Alternate & Pyrazolyl & $\overline{\mathrm{Ag}(\mathrm{I})}$ & 1D & [96] \\
\hline & $\boldsymbol{L 5 4}$ and $\boldsymbol{L 5 5}$ & 1,3-Alternate & $\begin{array}{l}\text { Cyano } \\
\text { S }\end{array}$ & $\operatorname{Ag}(\mathrm{I})$ & $1 \mathrm{D}, 2 \mathrm{D}$ & [97] \\
\hline & $L 56$ & 1,3-Alternate & $\begin{array}{c}\text { Carboxylate } \\
+\mathrm{N}\end{array}$ & $\begin{array}{c}\mathrm{Cu}(\mathrm{II}), \mathrm{Mn}(\mathrm{II}) \text { et } \\
\mathrm{Zn}(\mathrm{II})\end{array}$ & 1D & [98] \\
\hline & L57-L59 & 1,3-Alternate & $\begin{array}{c}\text { Pyridyl } \\
\text { S }\end{array}$ & $\mathrm{Hg}(\mathrm{II})$ & $3 \mathrm{D}, 2 \mathrm{D}, 1 \mathrm{D}$ & [99] \\
\hline & $L 58$ & 1,3-Alternate & Pyridyl & $\mathrm{Cd}(\mathrm{II}), \mathrm{Fe}(\mathrm{II}), \mathrm{Co}(\mathrm{II})$ & $2 \mathrm{D}, 3 \mathrm{D}$ & [92-93] \\
\hline & $L 58$ & 1,3-Alternate & Pyridyl & $\mathrm{Ag}(\mathrm{I})$ & $1 \mathrm{D}, 3 \mathrm{D}$ & {$[100]$} \\
\hline
\end{tabular}




\begin{tabular}{|l|c|c|c|c|c|c|}
\hline & L60-L62 & 1,3 -Alternate & $\begin{array}{c}\text { Pyrazolyl } \\
\mathrm{S}\end{array}$ & $\operatorname{Ag}(\mathrm{I})$ & 3D $, 2 \mathrm{D}, 1 \mathrm{D}$ & {$[96]$} \\
\hline
\end{tabular}

A possibility to overcome the serendipity in the formation of calixarene based $\mathrm{CP}$ has been demonstrated by the partial substitution of the lower/upper rim or the blocking of the conformation (cone or 1,3-Alternate, essentially). The strategy based on the tetra substitution of CA and TCA is promising for the dimensionality control of the formed CP, but for the moment, the work is at its infancy.

The results gathered in this review are the basis of the initial phase of development in this emerging and this promising field concerning the formation of functional Coordination Polymers. In this review, several reported CP present some properties, and in the future an increasing number of functional calixarene based CP will still be reported. Computational calculations can be used as a theoretical support and guideline for the preparation and application of new macrocycle-based Coordination Polymers. In the coming decade we expect a large number of new targeted Coordination Polymers with dedicated applications and desired physical properties. Although the investigation in the CP field are widely expanding involving various types of organic ligands the present overview on $\mathrm{CP}$ based on calixarene shows a extremely large potential of these macrocycles to be used as molecular building blocks in the further creation of new functional materials.

\section{ACKNOWLEDGMENTS}

Pr. M. W. Hosseini is warmly acknowledged for his continuous support and huge contribution to this work.

We thank the Russian Science Foundation (grant $N^{\circ}$ 15-13-30006) for financial support. The University of Strasbourg, the International Centre for Frontier Research in Chemistry (icFRC), Laboratory of excellence LabEx CSC, the Institut Universitaire de France, the CNRS are also gratefully acknowledged.

\section{REFERENCES}

[1] (a) B. F. Abrahams, B. F. Hoskins, R. Robson J. Am. Chem. Soc. 113 (1991) 3606-3607;

(b) S. R. Batten, R. Robson Angew. Chem. Int. Ed. 37 (1998) 1460-1494.

[2] M. W. Hosseini CrystEngComm. 6 (2004) 318-322.

[3] (a) S. R. Batten, N. R. Champness, X-M. Chen, J. Garcia-Martinez, S. Kitagawa, L. Öhrström, M. O'Keeffe, M. Paik Suh J Reedijk CrystEngComm14 (2012) 3001-3004 ;

(b) R. Batten, N. R. Champness, X-M. Chen, J. Garcia-Martinez, S. Kitagawa, L. Öhrström, M. O'Keeffe, M. Paik Suh, J Reedijk Pure and Applied Chemistry 85 (2013) 1715-1724.

[4] N. R. Champness Dalton Trans 40 (2011) 10311-10315.

[5] (a) J. D. Dunitz Chem. Commun. (2003)545-548;

(b) S. L. Price CrystEngComm. 6 (2004) 344-354;

(b) J. D. Dunitz, A. Gavezzoti Angew. Chem. Int. Ed. 44 (2004) 1766-1787.

[6] (a) A. J. Blake N. R. Champness P. Hubberstey W.-S. Li M. A. Withersby M. Schröder Coord. Chem. Rev. 1831999 117-138;

(b) B. Moulton, M. J. Zaworotko Chem. Rev. 101 (2001) 1629-1658;

(c) M. Eddaoudi, D. B. Moler, H. Li, B. Chen, T.M. Reineke, M. O'Keeffe, O. M. Yaghi Acc. Chem. Res. 34 (2001) 319-330; 
(d) C. Janiak Dalton Trans. (2003) 2781-2804;

(e) L. Carlucci, G. Ciani, D. M. Proserpio Coord. Chem. Rev. 246 (2003) 247-289;

(f) S. Kitagawa, R. Kitaura, S. Noro, Angew. Chem. Int. Ed. 43 (2004) 2334-2375;

(g) G. Férey, C. Mellot-Draznieks, C. Serre, F. Millange Acc. Chem. Res. 38 (2005) 218-225;

(h) D. Bradshaw, J. B. Claridge, E. J. Cussen, T. J. Prior, M. J. Rosseinsky Acc. Chem. Res. 38 (2005) 273282;

(i) S. Kitagawa, K. Uemura, Chem. Soc. Rev. 34 (2005) 109-119;

(j) D. Maspoch, D. Ruiz-Molina,J. Veciana Chem. Soc. Rev. 36 (2007) 770-818;

(k) J. R. Long, O. M. Yaghi Chem. Soc. Rev. 38 (2009) 1213-1214;

(1) Chem. Soc. Rev. 38 (2009) themed issue on metal-organic frameworks;

(m) C. Janiak, J. L. Vieth New J. Chem. 34 (2010) 2366-2388;

(n) W. L. Leong, J. J. Vittal Chem. Rev. 111 (2011) 688-764;

(o) Chem. Rev. 112 (2012) Metal-Organic Frameworks special issue.

[7] (a) H. Zhang, R. Zou, Y. Zhao Coord. Chem. Rev. 292 (2015) 74-90;

(b) S. Park, S. Y. Lee, K.-M. Park, S. S. Lee Acc. Chem. Res. 45 (2012) 391-403.

[8] (a) B.F. Abrahams, B. F. Hoskins, D. M. Michail, R. Robson Nature 369 (1994) 727-729;

(b) R. A. Smaldone, R. S. Forgan, H. Furukawa, J. J. Gassensmith, A. M. Z. Slawin, O. M. Yaghi, J. F. Stoddart Angew. Chem. Int. Ed. 49 (2010) 8630-8634;

(c) G. Brancatelli, R. De Zorzi, N. Hickey, P. Siega, G. Zingone, S. Geremia Cryst. Growth Des. 12 (2012) 5111-5117.

[9] (a) H. Kumagai, M. Hasegawa, S. Miyanari, Y. Sugawa, Y. Sato, T. Hori, S. Ueda, H. Kamiyama, S. Miyano Tetrahedron Lett. 38 (1997) 3971-3974;

(b) H. Akdas, L. Bringel, E. Graf, M. W. Hosseini, G. Mislin ,J. Pansanel, A. De Cian, J. Fischer Tetrahedron Lett. 39 (1998) 2311-2314.

[10] P. Rao, M. W. Hosseini, A. De Cian, J. Fischer Chem. Commun. (1999) 2169-2170.

[11] S. Shinkai Tetrahedron 49 (1993) 8933-9150.

[12] (a) C.D. Gutsche in Calixarenes Revised: Monographs in Supramolecular Chemistry Vol. 6 The Royal Society of Chemistry Cambridge (1998);

(b) Calixarenes (Eds. Z. Asfari, V. Böhmer, J. Harrowfield, J. Vicens) Kluwer Academic Dordrecht (2001);

(c) Calixarenes and Beyond (Eds. P. Neri, J. Sessler, M-X.Wang) Springer International Publishing (2016).

[13] (a) T. Kajiwara, N. Iki, M. Yamashita Coord. Chem. Rev. 251 (2007) 1734-1746 ;

(b) G. Karotsis, S. J. Teat, W. Wernsdorfer, S. Piligkos, S. J. Dalgarno, E. K. Brechin Angew. Chem. Int. Ed. 48 (2009) 8285-8288;

(c) B. S. Creavena, D. F. Donlona, J. McGinley Coord. Chem. Rev. 253 (2009) 893-962;

(d) Y. Bi, S. Du, W. Liao Coord. Chem. Rev. 276 (2014) 61-72.

[14] G. Mislin, E. Graf, M. W. Hosseini, A. De Cian, J. Fischer Tetrahedron Lett. 40 (1999) 1129-1132.

[15] G. Mislin ,E. Graf, M. W. Hosseini, A. De Cian, J. Chem. Soc. Chem. Commun (1998) 1345-1346.

[16] Y. Bi, W. Liao, X. Wang, R. Deng, H. Zhang Eur. J. Inorg. Chem. (2009) 4989-4994.

[17] J. Sykor,a M. Himl, I. Stibor, I. Cisarova, P. Lhotak Tetrahedron 63 (2007) 2244-2248.

[18] M. Yamada, Y. Kondo, N. Iki, C. Kabuto, F. Hamada Tetrahedron Lett. 49 (2008) 3906-3911.

[19] M. Yamada, F. Hamada, CrystEngComm 13 (2011) 2494-2499.

[20] M. Yamada, Y. Shimakawa, Y. Kondo, F. Hamada CrystEngComm 12 (2010) 1311-1315.

[21] Y. Kondo, K. Endo, F. Hamada Chem. Commun. (2005) 711-712.

[22] M. Liu, W. Liao Chem. Commun. (2012) 5727-5729.

[23] M. Liu, W. Liao J. Mol. Struct. 1038 (2013) 206-210.

[24] H. Tan, S. Du, Y. Bia, W. Liao Chem. Commun. (2013) 8211-8213.

[25] W. Liu, M. Liu, S. Du, Y. Li, W. Liao J. Mol. Struct. 1060 (2014) 58-62.

[26] K. Su, F. Jiang, J. Qian, J. Pang, F. Hu, S. M. Bawaked, M. Mokhtar, S. A. Al-Thabaiti, M. Hong CrystEngComm 17 (2015) 1750-1753.

[27] M. Liu, S. Du, W. Liao, J. Mol. Struct. 1049 (2013) 310-314

[28] Q. Shi, W-Z. Luo, B. Li, Y-P. Xie, T. Zhang Cryst. Growth Des. 16 (2016) 493-498.

[29] L. Salmon, P. Thuéry, M. Ephritikhine Dalton Trans. (2006) 3629-3637.

[30] C. Redshaw, M. Walton, K. Michiue, Y. Chao, A. Walton, P. Elo, V. Sumerin, C. Jiang, M. R. J. Elsegood Dalton Trans. (2015) 12292-12303.

[31] P. P. Cholewa, C. M. Beavers, S. J. Teat, S. J. Dalgarno Cryst. Growth Des. 13 (2013) 2703-2706

[32] S. Kennedy, G. Karotsis, C. M. Beavers, S. J. Teat, E. K. Brechin, S. J. Dalgarno Angew. Chem. Int. Ed. 49 (2010) 4205-4208.

[33] S. P. Bew, A. D. Burrows, T. Düren, M. F. Mahon, P. Z. Moghadam, V. M. Sebestyen, S. Thurston Chem. Commun. (2012) 4824-4826 
[34] P. P. Cholewa, C. M. Beavers, S. J. Teat, S. J. Dalgarno Chem. Commun. 49 (2013) 3203-3205.

[35] S. J. Dalgarno, K. M. Claudio-Bosque, J. E. Warren, T. E. Glass, J. L. Atwood Chem. Commun. (2008) 1410-1412.

[36] L-L. Liu, Z-G. Ren, L-W. Zhu, H-F. Wang, W-Y. Yan, J-P. Lang Cryst. Growth Des. 11 (2011) 3479-3488

[37] L-L. Liu ,L-M. Wan, Z-G. Ren, J-P. Lang Inorg. Chem. Comm. 14 (2011) 1069-1072.

[38] G. Mislin, E. Graf, M. W. Hosseini, A. De Cian, N. Kyritsakas, J. Fischer Chem. Commun. (1998) 25452546.

[39] H. R. Webb, M. J. Hardie, C. L. Raston Chem. Eur. J. 7 (2001) 3616-3620.

[40] J. L. Atwood, L. J. Barbour, S. Dalgarno, C. L. Raston, H. R. Webb J. Chem. Soc. Dalton Trans. (2002) 4351-4356.

[41] S. Dalgarno, C. L. Raston Chem. Commun. (2002) 2216-2217.

[42] S J. Dalgarno, M. J. Hardie, C. L. Raston Cryst. Growth Des. 4 (2004) 227-234.

[43] M. Makha, A. N. Sobolev, C. L. Raston Chem. Commun. (2006) 57-59.

[44] F. Gandara, E. Gutierrez-Puebla, M. Iglesias, N. Snejko, M. A. Monge Cryst. Growth Des. 10 (2010) 128134.

[45] P. Thuéry CrystEngComm14 (2012) 6369-6373.

[46] S. J. Dalgarno, J. L. Atwood, C. L. Raston Cryst. Growth Des. 7 (2007) 1762-1770.

[47] C. Chen, J-F. Ma, B. Liu, J. Yang, Y-Y. Liu Cryst. Growth Des. 11 (2011) 4491-4497.

[48] W. Liao, C. Liu, X. Wang, G. Zhu ,X. Zhao, H. Zhang CrystEngComm. 11 (2009) 2282-2284.

[49] A. Husain, C. L. Oliver CrystEngComm 17 (2015) 3023-3030.

[50] J. Li, S. Zhang, Y-G. Chen, X. Du, H. Yu, J. Yu J Incl Phenom Macrocycl Chem 81 (2015) 485-491.

[51] M. Wu, D. Yuan, L. Han, B. Wu, Y. Xu, M. Hong Eur. J. Inorg. Chem. (2006) 526-530.

[52] B. Chen, D. Yuan, M. Wu, F. Jiang, M. Hong Z. Anorg. Allg. Chem. 635 (2009) 1669-1672.

[53] Q-L. Guo, W-X. Zhu, S. Gao, S-L. Ma, S-J. Dong, M-Q. Xu Inorg. Chem. Comm. 7 (2004) 467-470.

[54] U. M. R. Kunda, M. Yamada ,H. Katagiri, F. Hamada ,RSC Adv. 6 (2016) 19155-19159.

[55] U. M. R. Kunda, M. Yamada, T. Kimuro, H. Katagiri, Y. Kondoe, F. Hamada RSC Adv. 5 (2015) 3014030144.

[56] K. Xiong, F. Jiang, M. Wu, Y. Gai, Q. Chen, S. Zhang, J. Ma, D. Han, M. Hong J. Sol. St. Chem. 192 (2012) 215-220.

[57] S. J. Dalgarno, M. J. Hardie, J. E. Warren, C. L. Raston Dalton Trans. (2004) 2413-2416.

[58] I. Ling, R. A. Boulos, B. W. Skelton, A. N. Sobolev, Y. Alias, C. L. Raston Cryst. Growth Des. 13 (2013) 2025-2035.

[59] M. Makha, A. N. Sobolev Cryst. Growth Des. 7 (2007) 1441-1445.

[60] S. J. Dalgarno, M. J. Hardie, J. L. Atwood, C. L. Raston Inorg. Chem. 43 (2004) 6351-6356.

[61] Y. Liu, W. Liao, Y. Bi, X. Wang, H. Zhang Cryst. Growth Des. 9 (2009) 5311-5318.

[62] M. Yamada, F. Hamada CrystEngComm 15 (2013) 5703-5712.

[63] L. Erra, C. Tedesco, G. Vaughan, M. Brunelli, F. Troisi, C. Gaeta, P. Neri CrystEngComm 12 (2010) 34633466.

[64] S. J. Dalgarno, M. J. Hardie, J. L. Atwood, J. E. Warren, C. L. Raston New J. Chem. 29 (2005) 649-652.

[65] J. Plutnar, J. Rohovec, J. Kotek, Z. Zak, I. Lukes Inorg. Chim. Acta 335 (2002) 27-35.

[66] A. D. Martin, A. N. Sobolev, M. A. Spackman, C. L. Raston Cryst. Growth Des. 9 (2009) 3759-3764.

[67] G. A. Kostin, A. O. Borodin, V. G. Torgov, N. V. Kuratieva, D. Y. Naumov, S. I. Miroshnichenko, V. I. Kalchenko J Incl Phenom Macrocycl Chem 59 (2007) 45-52.

[68] J. Y. Lee, S. Y. Lee, J. Seo, C. S. Park, J. N. Go, W. Sim, S. S. Lee Inorg. Chem. 46 (2007) 6221-6223.

[69] J. Y. Lee, S. Y. Lee, W. Sim, K-M. Park, J. Kim, S. S. Lee J. Am. Chem. Soc. 130 (2008) 6902-6903.

[70] J. Y. Lee, H. J. Kim, J. H. Jung, W. Sim, S. S. Lee J. Am. Chem. Soc. 130 (2008) 13838-13839.

[71] J-Y. Kim, I-H. Park, J. Y. Lee, J-H. Lee, K-M. Park, S. S. Lee Inorg. Chem. 52 (2013) 10176-10182.

[72] J. Y. Lee, S. Y. Lee, J. Seo, S. Park, J. Kwon, W. Sim, S. S. Lee Inorg. Chem. 48 (2009) 8934-8939.

[73] P. D. Beer, P. A. Gale, Z. Chen, M. G. B. Drew, J. A. Heath, M. I. Ogden, H. R. Powell. Inorg. Chem. 36 (1997) 5880-5893.

[74] P. D. Beer, M. G. B. Drew, P. A. Gale, M. I. Ogden, H. R. Powell. CrystEngComm 2 (2000) 164-168.

[75] (a) J. Olguín, V. Gómez-Vidales, E. Muñoz, R.A. Toscano, I. Castillo Inorg. Chem. Comm. 9 (2006) 10961098 ;

(b) J. Olguín, V. Gómez-Vidales, S. Hernández-Ortega, R.A. Toscano, E. Muñoz, I. Castillo Supramolecul. Chem. 21 (2009) 502-509.

[76] A. Castillo, J. L. Martínez, P. R. Martínez-Alanis, I. Castillo Inorg. Chim. Acta 363 (2010) 1204-1211.

[77] L.-L. Liu, J. Chen, C.-X. Yu, W.-X. Lv ,H.-Y. Yu, X.-Q. Cui, L. Liu Dalton Trans. 46 (2017) 178-185.

[78] Y-J. Liu, J-S. Huang, S. S-Y. Chui, C-H. Li, J-L. Zuo, N. Zhu, C-M. Che Inorg. Chem. 47 (2008)1151411518. 
[79] C. Redshaw, O. Rowe, D. L. Hughes, A-M. Fuller, I. A. Ibarra, S. M. Humphrey Dalton Trans. 42 (2013) 1983-1986.

[80] K-M. Park, E. Lee, C. S. Park, S. S. Lee Inorg. Chem. 50 (2011) 12085-12090.

[81] E. Lee, Y. Kim, J. Heo, K-M. Park Cryst. Growth Des. 15 (2015) 3556-3560.

[82] E. Lee, H. Ju ,S.-H. Moon, Y. Kang, K.-M. Park Bull. Korean Chem. Soc. 36 (2015) 2124-2127.

[83] Y-Y. Liu, C. Chen, J-F. Ma, J. Yang CrystEngComm 14 (2012) 6201-6214.

[84] L. V. Tsymbal, Y. D. Lampeka, V. I. Boyko, V. I. Kalchenko, V. V. Shishkina, O. V. Shishkin CrystEngComm 16 (2014) 3707-3711.

[85] M. N. Kozlova, S. Ferlay, S. E. Solovieva, I. S. Antipin, A. I. Konovalov, N. Kyritsakas, M. W. Hosseini Dalton Trans. (2007) 5126-5131.

[86] M. N. Kozlova, S. Ferlay, S. E. Solovieva, I. S. Antipin, A. I. Konovalov, N. Kyritsakas, M. W. Hosseini Chem. Commun. (2009) 2514-2516.

[87] H. Akdas, E. Graf, M. W. Hosseini ,A. De Cian, J. McB. Harrowfield Chem. Commun. (2000) 2219-2220.

[88] J.-Y. Kim, K. Kim, K-M. Park, S.S. Lee Bull. Korean Chem. Soc. 35 (2014) 289-292.

[89] K. Kim, S. Park, K-M. Park, S. S. Lee Cryst. Growth Des. 11 (2011) 4059-4067.

[90] Z. Zhang, A. Drapailo, Y. Matvieiev, L. Wojtas, M. J. Zaworotko Chem. Commun. (2013) 8353-8355.

[91] A. Ovsyannikov, M. N. Lang, S. Ferlay, S. E. Solovieva, I. S. Antipin, A. I. Konovalov, N. Kyritsakas, M. W. Hosseini Dalton Trans. (2013)116-126.

[92] A. Ovsyannikov, S. Ferlay, S. E. Solovieva, I. S. Antipin, A. I. Konovalov, N. Kyritsakas, M. W. Hosseini CrystEngComm (2014) 3765-3772.

[93] A. Ovsyannikov, S. Ferlay, S. E. Solovieva, I. S. Antipin, A. I. Konovalov, N. Kyritsakas, M. W. Hosseini Macroheterocycles 8 (2015) 113-119.

[94] A. Ovsyannikov, S. Ferlay, S. E. Solovieva, I. S. Antipin, A. I. Konovalov, N. Kyritsakas, M. W. Hosseini Dalton Trans. (2013) 9946-9953.

[95] A. Ovsyannikov, S. Ferlay, S. E. Solovieva, I. S. Antipin, A. I. Konovalov, N. Kyritsakas, M. W. Hosseini Macroheterocycles 9 (2016) 17-22.

[96] A. Ovsyannikov, M. H. Noamane, R. Abidi, S. Ferlay, S. E. Solovieva, I. S. Antipin, A. I. Konovalov, N. Kyritsakas, M. W. Hosseini CrystEngComm 18 (2016) 691-703.

[97] A. Ovsyannikov, S. Ferlay, S. E. Solovieva, I. S. Antipin, A. I. Konovalov, N. Kyritsakas, M. W. Hosseini Russian Chemical Bulletin 64 (2015) 1955-1962.

[98] A. Ovsyannikov, S. Ferlay, S. E. Solovieva, I. S. Antipin, A. I. Konovalov, N. Kyritsakas, M. W. Hosseini Macroheterocycles 10 (2017) 147-153.

[99] A. Ovsyannikov, S. Ferlay, S. E. Solovieva, I. S. Antipin, A. I. Konovalov, N. Kyritsakas, M. W. Hosseini Inorg. Chem. 52 (2013) 6776-6778.

[100] A. Ovsyannikov, S. Ferlay, S. E. Solovieva, I. S. Antipin, A. I. Konovalov, N. Kyritsakas, M. W. Hosseini Dalton Trans. 43 (2014) 158-165.

[101] (a) J. L. Atwood, L. J. Barbour, A. Jerga Science 296 (2002) 2367-2369;

(b) J. L. Atwood, L. J. Barbour, P. K. Thallapally, T. B. Wirsig Chem. Commun. (2005) 51-52;

(c) P. K. Thallapally, L. Dobrzańska, T. R. Gingrich, T. B. Wirsig, L. J. Barbour, J. L. Atwood Angew. Chem. Int. Ed. 45 (2006) 6506-6509.

[102] P. K. Thallapally, B. P. McGrail „J. L. Atwood Chem. Commun. (2007) 1521-1522.

[103] N. S. Venkataramanan, R. Sahara, H. Mizuseki, Y. Kawazoe J. Phys. Chem. C 112 (2008) 19676-19679.

[104] G. S. Ananchenko, I. L. Moudrakovski, A. W. Coleman, J. A. Ripmeester Angew. Chem. Int. Ed. 47 (2008) 5616-5618

[105] O. Kahn Molecular MagnetismVCH: New York NY (1993).

[106] C. B. Aakeröy, N. R. Champness, C. Janiak CrystEngComm 12 (2010) 22-43. 